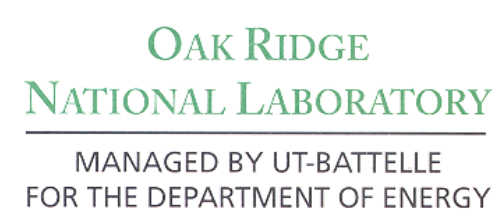

MANAGED BY UT-BATTELLE FOR THE DEPARTMENT OF ENERGY

\section{A Stochastic Method for Estimating the Effect of Isotopic Uncertainties in Spent Nuclear Fuel}

M. D. DeHart 


\section{DOCUMENT AVAILABILITY}

Reports produced after January 1, 1996, are generally available free via the U.S. Department of Energy (DOE) Information Bridge.

Web site http://www.osti.gov/bridge

Reports produced before January 1, 1996, may be purchased by members of the public from the following source.

National Technical Information Service

5285 Port Royal Road

Springfield, VA 22161

Telephone 703-605-6000 (1-800-553-6847)

TDD 703-487-4639

Fax 703-605-6900

E-mail info@ntis.fedworld.gov

Web site http://www.ntis.gov/support/ordernowabout.htm

Reports are available to DOE employees, DOE contractors, Energy Technology Data Exchange (ETDE) representatives, and International Nuclear Information System (INIS)

representatives from the following source.

Office of Scientific and Technical Information

P.O. Box 62

Oak Ridge, TN 37831

Telephone 865-576-8401

Fax 865-576-5728

E-mail reports@adonis.osti.gov

Web site http://www.osti.gov/contact.html

This report was prepared as an account of work sponsored by an agency of the United States government. Neither the United States government nor any agency thereof, nor any of their employees, makes any warranty, express or implied, or assumes any legal liability or responsibility for the accuracy, completeness, or usefulness of any information, apparatus, product, or process disclosed, or represents that its use would not infringe privately owned rights. Reference herein to any specific commercial product, process, or service by trade name, trademark, manufacturer, or otherwise, does not necessarily constitute or imply its endorsement, recommendation, or favoring by the United States government or any agency thereof. The views and opinions of authors expressed herein do not necessarily state or reflect those of the United States government or any agency thereof. 
Computational Physics and Engineering Division (10)

\title{
A Stochastic Method for Estimating the Effect of Isotopic Uncertainties in Spent Nuclear Fuel
}

\author{
M. D. DeHart \\ Oak Ridge National Laboratory, \\ P.O. Box 2008, \\ Oak Ridge, TN 37831-6370
}

Date Published: September 2001

Prepared by the

OAK RIDGE NATIONAL LABORATORY

Oak Ridge, Tennessee 37831

managed and operated by

UT-Battelle, LLC

for the

U.S. DEPARTMENT OF ENERGY

under contract DE-AC05-00OR22725 



\section{CONTENTS}

LIST OF FIGURES

V

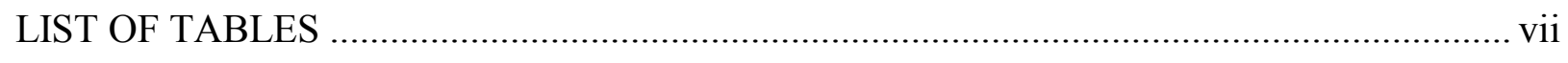

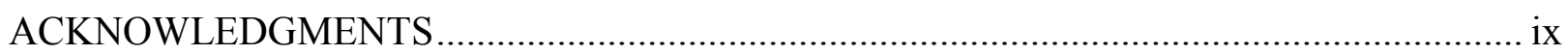

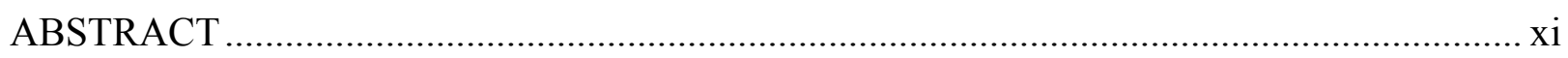

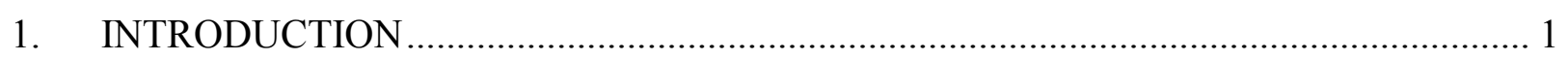

2. STATISTICAL BACKGROUND ...................................................................... 3

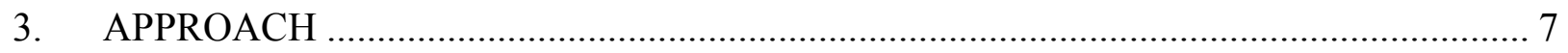

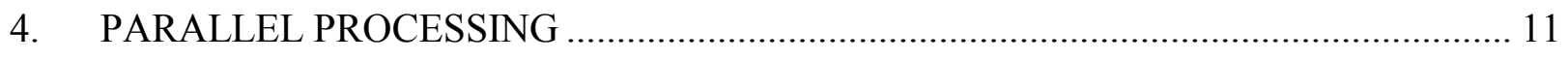

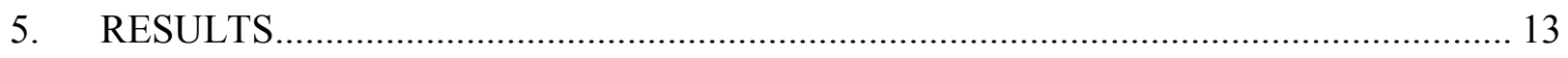

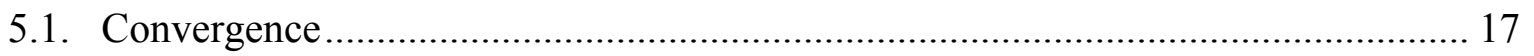

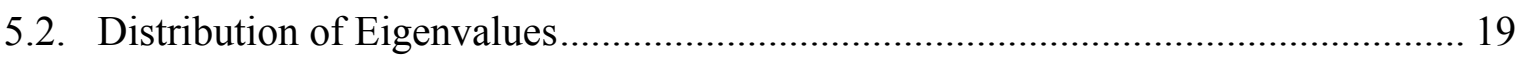

5.3. Actinide-Only vs. "Full” Burnup Credit ............................................... 23

5.4. Conservatism of Bounding Approach ...................................................... 26

6. CONCLUSIONS .............................................................................................. 31

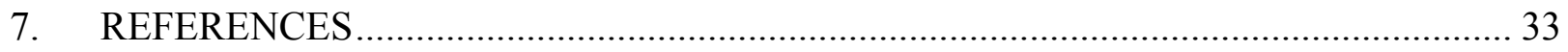

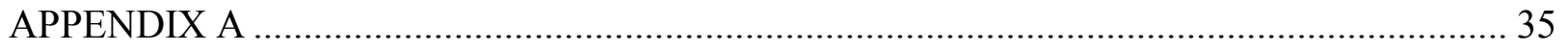

KRONOS Fortran-90 Program Listing ............................................................... 37

APPENDIX B: SAMPLE BASELINE INPUT MODELS USED BY KRONOS ..................... 53

Sample 1: KRONOS KENO Cask model, non-uniform axial profile, actinides only, $20 \mathrm{GWd}$ /MTU .................................................................................... 55

Sample 2: KRONOS KENO pin model, non-uniform axial profile, actinides + fission products, $40 \mathrm{GWd} / \mathrm{MTU}$ 
Sample 3: KRONOS XSDRN pin-cell model, actinides + fission products, $60 \mathrm{GWd} / \mathrm{MTU}$ 


\section{LIST OF FIGURES}

Figure

$\underline{\text { Page }}$

1. Convergence of mean value of $k$ for $60 \mathrm{GWd} / \mathrm{MTU}$ cask models. ................................... 18

2. Convergence of population standard deviation for $60 \mathrm{GWd} / \mathrm{MTU}$ cask models................... 19

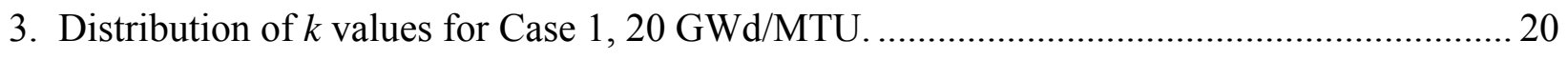

4. Distribution of $k$ values for Case $2,40 \mathrm{GWd} / \mathrm{MTU}$...................................................... 21

5. Distribution of $k$ values for Case $3,60 \mathrm{GWd} / \mathrm{MTU}$.................................................... 22

6. Fission product reactivity worth as a function of burnup.............................................. 25

7. Uncertainty due to fission products as a function of burnup............................................26

8. Probability plot for KENO cask calculations, actinides + fission products. ......................... 27

9. Probability plot for KENO cask calculations, actinides only......................................... 28 


\section{LIST OF TABLES}

Table

$\underline{\text { Page }}$

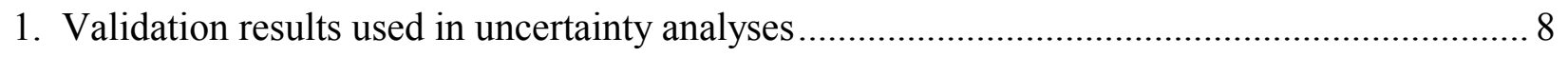

2. Results of KRONOS calculations for various configurations and burnups. ......................... 14

3. Reactivity worth of fission products and associated uncertainties .................................. 24 


\section{ACKNOWLEDGMENTS}

The author acknowledges the following individuals for their various contributions which made this work possible: C. K. Bayne for his assistance in developing the statistical theory described in this report, J. J. Sapyta and J. Pegram of Framatome ANP for their comments and suggestions in the genesis of this study, S. W. Willoughby for installation and support of the MPI package on the local workstation cluster, and W. C. Carter for her high standards, attention to detail, and rapid preparation of this report. Finally, the author acknowledges the review and comments provided by C. V. Parks, C. K. Bayne, I. C. Gauld and J. C. Wagner. 


\section{ABSTRACT}

This report describes a novel approach developed at the Oak Ridge National Laboratory (ORNL) for the estimation of the uncertainty in the prediction of the neutron multiplication factor for spent nuclear fuel. This technique focuses on burnup credit, where credit is taken in criticality safety analysis for the reduced reactivity of fuel irradiated in and discharged from a reactor. Validation methods for burnup credit have attempted to separate the uncertainty associated with isotopic prediction methods from that of criticality eigenvalue calculations. Biases and uncertainties obtained in each step are combined additively. This approach, while conservative, can be excessive because of aphysical assumptions employed. This report describes a statistical approach based on Monte Carlo sampling to directly estimate the total uncertainty in eigenvalue calculations resulting from uncertainties in isotopic predictions. The results can also be used to demonstrate the relative conservatism and statistical confidence associated with the method of additively combining uncertainties.

This report does not make definitive conclusions on the magnitude of biases and uncertainties associated with isotopic predictions in a burnup credit analysis. These terms will vary depending on system design and the set of isotopic measurements used as a basis for estimating isotopic variances. Instead, the report describes a method that can be applied with a given design and set of isotopic data for estimating design-specific biases and uncertainties. 


\section{INTRODUCTION}

During the last decade, significant effort has been directed to improve estimates of the reactivity worth of spent nuclear fuel for storage and transportation. Currently, spent fuel storage in dry casks is licensed under the requirement that the cask would remain subcritical if loaded with fresh fuel. In other words, no credit is taken for the reduction in the fuel reactivity as a result of in-reactor burnup and post-irradiation decay. This approach can be improved by applying burnup credit (i.e., taking credit for some or all of the reactivity decrement associated with fuel burnup) allowing increased cask loading or loading with higher initial enrichments than would be possible if all fuel were assumed to be fresh. Ongoing efforts in the U.S. seek to obtain licensing approval of burnup credit methods for cask design, for dry storage, transportation, and disposal applications.

Although the isotopic contents of fresh fuel are well quantified from the manufacturing process, the contents of spent fuel cannot be directly determined without destructive assay. Thus burnup credit approaches rely on a calculated estimate of spent fuel isotopic compositions that are used in subsequent criticality analyses. The two step process of calculating spent fuel contents followed by a criticality calculation must be validated in some manner to demonstrate that the calculations are accurate, and to quantify any biases and uncertainties between calculations and reality. Various validation approaches have been proposed, including both independent validation of each phase of the process and integral validation of depletion and criticality calculations together.

This report discusses an approach for assessing the net effect of biases and uncertainties associated with depletion calculations together with those associated with the predicted neutron multiplication factor $(k)$. Such validation requires that any biases and uncertainties in the ability to predict isotopic concentrations be determined by comparison between calculations and measured data. However, the approach used in applying nuclide biases and uncertainties to obtain a conservative estimate of the neutron multiplication factor for a spent fuel configuration is not defined in any regulatory guidance or standard. The approach proposed by the United States Department of Energy (U.S. DOE) in support of transportation and storage burnup credit ${ }^{1,2}$ takes a very conservative approach by assuming all nuclides are at statistical extremes simultaneously. In other words, given biases and uncertainties determined from the comparison of calculated and measured data for a set of nuclides, the calculated concentrations for each nuclide are corrected by applying the bias, the uncertainty, and a multiplier on the uncertainty, so as to maximize predictions of fissile nuclides and minimize those of absorbers. This results in a conservative bound for the reactivity worth of spent fuel.

There is no reason to expect that actual nuclide inventories will vary from calculated predictions is such a manner. The bounding approach described above will yield concentrations that, when used in a criticality calculation, will provide an upper estimate on the value of $k$ for the configuration analyzed. Similarly, setting concentrations to the opposite extreme by minimizing fissile concentrations and maximizing absorber concentrations will result in a lower bound on $k$. The true value of $k$ is expected to lie between these two extremes. 
This report describes a method developed to assess the uncertainty in the computationally-predicted value of $k$ in terms of quantified uncertainties in isotopic concentrations. Estimates of isotopic biases and uncertainties in depletion calculations are obtained based on comparison between calculated and measured nuclide concentrations performed for a limited set of spent fuel samples. ${ }^{3}$ The goal is to obtain, with a statistical confidence, a best estimate and associated uncertainty for $k$ for a subcritical system. A conservative upper limit on the value of $k$ for that system can then be established without the excessive conservatism associated with other approaches.

Analyses described herein were performed to assess the uncertainty in the neutron multiplication factor in both a finite cask configuration $\left(k_{e f f}\right)$ and in an infinite lattice of pin cells $\left(k_{i n f}\right)$. For simplicity, the neutron multiplication factor will be referred to as simply $k$ in the following sections of this report. 


\section{STATISTICAL BACKGROUND}

In practice, the key parameter of interest for criticality safety in a spent nuclear fuel system is the neutron multiplication factor, $k$, to ensure an adequate subcritical margin. Proposed approaches, apply nuclide uncertainties in a bounding manner to conservatively estimate nuclide concentrations to be used in a subsequent criticality calculation. However, an alternate approach would be to estimate the uncertainty in $k$ directly with respect to individual nuclide concentrations. In setting calculated isotopic concentrations to their conservative limits, one is confident that one can conservatively estimate the reactivity of a spent fuel system. However, if one were to randomly vary spent fuel isotopics independently within the range of their estimated uncertainties, calculate the neutron multiplication factor for a given fuel configuration, and repeat this process multiple times, one would obtain a normal distribution of $k$ values corresponding to random variations in expected concentrations. The distribution itself will have a standard deviation, which can be used to set a confidence level on the prediction of $k$. To be meaningful; however, the selection of multiple random isotopic concentrations must be based on and representative of the expected bias and uncertainty associated with the calculated prediction of isotopic concentrations.

In the calculation of $k$ for a spent fuel system, nuclide concentrations are first estimated using a depletion method. The depletion method itself can be validated by comparison of measured spent fuel isotopic concentrations to corresponding concentrations calculated in a computational depletion model of the fuel sample. This process is repeated for as many spent fuel samples as possible. Given the measured $\left(\mathrm{M}_{\mathrm{i}}\right)$ and corresponding computed $\left(\mathrm{C}_{\mathrm{i}}\right)$ isotopic concentrations for each nuclide $i$ in each of $n$ spent fuel samples, with a measured-to-computed ratio $\mathrm{X}_{\mathrm{i}}=\mathrm{M}_{\mathrm{i}} / \mathrm{C}_{\mathrm{i}}$, one can calculate an average measured-to-computed ratio for each nuclide $i$ as:

$$
\bar{X}_{i}=\sum_{j=1}^{n}\left(M_{i, j} / C_{i, j}\right) / n
$$

An estimate of the standard deviation, $\mathrm{s}_{\mathrm{i}}$, associated with $\overline{\mathrm{X}}_{\mathrm{i}}$ is readily calculated as:

$$
s_{i}=\sqrt{\frac{\sum_{j=1}^{n}\left(X_{j}^{i}-\bar{X}_{i}\right)^{2}}{n-1}}
$$

The estimated standard deviation represents the uncertainty in the prediction of $\overline{\mathrm{X}}_{\mathrm{i}}$. This uncertainty is due to random deviations resulting from modeling uncertainties, operational

variations, design uncertainties, random measurement errors and other factors. For each $\overline{\mathrm{X}}_{\mathrm{i}}$, a corresponding $\mathrm{s}_{\mathrm{i}}$ can be easily computed using Eq. (2). This statistical procedure is discussed in more detail in Ref. 4. 
Given the average $\mathrm{M} / \mathrm{C}$ ratio, $\overline{\mathrm{X}}_{\mathrm{i}}$, for a given isotope, one can improve the calculated estimate for a subsequent fuel depletion calculation by correcting the calculated concentration $\mathrm{C}$ using the relationship:

$$
\mathrm{M}_{\mathrm{i}}^{*}=\mathrm{C}_{\mathrm{i}}^{*} \times \overline{\mathrm{X}}_{\mathrm{i}} .
$$

$\mathrm{M}_{\mathrm{i}}{ }^{*}$ is the isotopic concentration that would be expected for a measurement of a concentration that was calculated as $\mathrm{C}_{\mathrm{i}}$. However, the value of $\bar{X}_{\mathrm{i}}$ is an estimate based on the limited $n$ measurements, and has an associated uncertainty. In an approach to conservatively estimate an upper $\left(\mathrm{MC}_{+}^{*}\right)$ or lower $\left(\mathrm{MC}_{-}^{*}\right)$ bound for $\mathrm{MC}^{*}$, one may use $\mathrm{M}_{\mathrm{i} \pm}{ }^{*}=\mathrm{C}_{\mathrm{i}} \cdot\left(\overline{\mathrm{X}}_{\mathrm{i}} \pm \mathrm{T}_{\mathrm{n}} \cdot \mathrm{s}_{\mathrm{i}}\right)$, where $\mathrm{T}$ is a tolerance factor assigned to bound the limits of $\overline{\mathrm{X}}_{\mathrm{i}}$ at a given confidence level; the value of $\mathrm{T}$ also depends on the number of measurements, $n$, used to calculate $\overline{\mathrm{X}}_{\mathrm{i}}$. Note that $\overline{\mathrm{X}}_{\mathrm{i}}$ and $\mathrm{s}_{\mathrm{i}}$ are unique for each nuclide used.

The bounding approach described earlier sets fissile nuclide concentrations to the maximum of the range, and non-fissile absorber nuclide concentrations to the minimum of the range, where the range itself is determined on a nuclide by nuclide basis. In reality, we expect that for a calculated isotopic concentration of $\mathrm{C}$ for a given nuclide at a specific burnup state, the actual value $\mathrm{M}^{*}$ of the isotopic concentration (if measured) would lie between $\mathrm{MC}_{+}{ }^{*}$ and $\mathrm{MC}_{-}$* (to a specified level of confidence). Furthermore, there is reason to expect (because the distribution is largely if not wholly due to random errors) that for multiple measurements, values of $\mathrm{M}$ would be normally distributed within $\mathrm{MC}_{+}{ }^{*}$ and $\mathrm{MC}_{-}^{*}$ with a mean value close to $\mathrm{X}$. In fact, Ref. 5 suggests that $\mathrm{M} / \mathrm{C}$ ratios are normally distributed when sufficient data points are available to test the distribution.

It is possible to generate a distribution of the expected measured concentration of a given nuclide if we modify Eq. (3) to allow us to randomly select from the expected range of $\bar{X}_{i}$, according to the following:

$$
\mathrm{M}_{\mathrm{i}}^{* \mathrm{k}}=\mathrm{C}_{\mathrm{i}}\left(\overline{\mathrm{X}}_{\mathrm{i}}+\mathrm{R}_{\sigma}^{\mathrm{k}} \mathrm{s}_{\mathrm{i}}\right)
$$

Again, $\mathrm{M}_{\mathrm{i}}^{*}$ represents the expected concentration for a calculated concentration $\mathrm{C}_{\mathrm{i}}$ for nuclide $i$ in spent fuel (i.e, the bias-corrected isotopic concentration). However, since we actually expect $\mathrm{M}_{\mathrm{i}}^{*}$ to fall within a normal distribution characterized by $\mathrm{s}_{\mathrm{i}}$, Eq. (4) gives us a means to randomly sample from the expected range of $\mathrm{M}_{\mathrm{i}}$ by calculating multiple instances $(k=1$ to $N)$. Note that $R_{\sigma}$ is a random number selected from a normal distribution, i.e., the distribution of $R_{\sigma}$ is not uniform in the range of -1 to 1 , but instead has a mean of 0 and a standard distribution of 1. Given adequate sampling, the mean value of $\mathrm{M}_{\mathrm{i}}^{*}$ over all $\mathrm{M}_{\mathrm{i}}^{* \mathrm{k}}$ would converge toward $\mathrm{C}_{\mathrm{i}} \times \overline{\mathrm{X}}_{\mathrm{i}}$, and $67 \%$ of the $\mathrm{M}_{\mathrm{i}}^{* \mathrm{k}}$ values would fall in the range of $\pm_{\mathrm{i}}$ of the mean. 
A limitation in this approach is the assumption of a good estimate of the standard deviation for chemical assay measurements. Unfortunately, existing chemical assay data are limited for many isotopes. With sufficient measurements, we can have some confidence that $s_{i}$ for the set of samples is a reasonable approximation of $\sigma_{i}$ for the population of all spent fuel. However, if a limited number of measurements are available, we must account for uncertainty in $\mathrm{s}_{\mathrm{i}}$, the estimate of $\sigma_{\mathrm{i}}$. In the bounding approach described in Ref. 4, a tolerance factor was applied as a multiplier to set an upper estimate on the standard deviation; the tolerance factor is selected based on the number of measurments available and the desired confidence level. Simply put, an upper estimate on $\mathrm{s}, \mathrm{s}_{\max }$, is defined as:

$$
s_{i, \max }=s_{i} \times T_{95 / 95}\left(n_{i}\right),
$$

where $\mathrm{n}_{\mathrm{i}}$ is the number of measurements for nuclide $i$ used as a basis for the calculation of $\mathrm{s}_{\mathrm{i}}$, and $\mathrm{T}_{95 / 95}$ represents a tolerance factor statistically derived to bound $95 \%$ of the population at a $95 \%$ confidence level. However, to apply this formulation in Eq. (4), one other change is necessary. The random number function $R_{\sigma}$ of Eq. (4) is designed to normally distribute calculated $M_{i}^{* k}$ values about the expected mean. However, when insufficient data are available to accurately determine the mean and standard deviation, it is more conservative to assume that the $\mathrm{M}_{\mathrm{i}}^{* \mathrm{k}}$ values vary randomly and uniformly within the bounds set by $M_{i}^{*} \pm s_{i, m a x}$. Hence, for nuclides with limited available data, Eq. (4) is rewritten as:

$$
\mathrm{M}_{\mathrm{i}}^{* \mathrm{k}}=\mathrm{C}_{\mathrm{i}}\left[\overline{\mathrm{X}}_{\mathrm{i}}+\mathrm{R}_{\mathrm{u}}^{\mathrm{k}} \mathrm{s}_{\mathrm{i}} \mathrm{T}_{95 / 95}\left(\mathrm{n}_{\mathrm{i}}\right)\right]
$$

where $R_{u}$ is a random number selected uniformly within the range -1 to 1 .

Although both Eqs. (4) and (6) provide a randomized concentration, the concentration is quite clearly constrained. The term "random concentration" used in this report refers to nuclide concentrations that are random within well quantified criteria that represent the random variations around an expected mean. Equation (6) limits concentrations to bounds defined by $C_{i}\left[X_{i} \pm s_{i} T_{95 / 95}\left(n_{i}\right)\right]$. And although $R_{\sigma}$ of Eq. (4) can vary within the range of $-\infty$ to $+\infty$, the mean is constrained to zero, and the distribution is normalized with a standard deviation of 1 , so that $99.5 \%$ of all modified concentrations would be found in the range of $C_{i}\left(X_{i} \pm 3 s_{i}\right)$. Additionally, since negative nuclide concentrations are not physically possible, any modified concentration calculated to be less than zero is set to zero.

For this study, it is assumed that predicted nuclide concentrations are themselves interdependent, and dependencies of one nuclide on others are manifest as a predictive bias. However, variations in these concentrations are independent of variations in concentrations for other nuclides, i.e., variations around the bias are random and independent of the variations 
observed for other nuclides. Under this assumption, one can then estimate the maximum potential variation in $k$ due to variations in nuclide concentrations by simultaneously varying nuclide concentrations within expected bounds for each nuclide using Eqs. (4) and (6). The following section describes the approach used to vary isotopic concentrations in a single criticality calculation, together with the procedure used to automate the preparation and processing of a large number of such criticality calculations. This set of calculations will provide a statistical estimate of the expected value of $k$ for a given configuration, together with an estimate of the uncertainty in $k$ due to isotopic uncertainties. 


\section{APPROACH}

In order to apply the formulations developed earlier, values of $\bar{X}_{i}$ and $s_{i}$ must be determined for each nuclide that is to be included in a criticality model. If isotopic assay data are not available for a given nuclide, it is not appropriate to include it in this type of analysis. For this work, results of validation analyses with the SAS2 ${ }^{6}$ sequence of SCALE and the ENDF/B-V-based 44-group cross-section library ${ }^{7}$ were used, as provided in Table 22 of Ref. 4. Values of $\bar{X}, \mathrm{~s}, \mathrm{n}$, and $\mathrm{T}_{95 / 95}$ (for $\mathrm{n} \leq 10$ ) from this reference are listed in Table 1.

In order to converge on the value of $k$ for a given configuration, a large number of independent calculations is necessary. Although it departs from the nature of Monte Carlo calculations typically applied in criticality safety analysis, the approach described here is a Monte Carlo analysis where the neutron multiplication factor $k$ is generated by a sequence of batches, each batch being a set of randomly varied isotopic concentrations. A sufficient number of batches (or histories) is necessary to obtain a convergence.

To serve this need, the computer code KRONOS was developed to automate the process of setting up, executing, and parsing the output of a large number of independent calculations with either the CSAS1X (1-D XSDRNPM) or the CSAS25 (3-D KENO V.a) sequences of SCALE ${ }^{8}$ KRONOS was developed and compiled using parallelization routines of MPI (Message Passing Interface ${ }^{9}$ to allow simultaneous execution of a number of calculations on a distributed network to improve execution time. A listing of the source for KRONOS is included in Appendix A.

KRONOS was developed to perform calculations based on a single input specification. Given a SCALE input listing (either CSAS1X or CSAS25 format), KRONOS identifies actinides and fission products in the fuel material specifications. Fuel isotopic concentrations, represented as $\mathrm{C}_{\mathrm{i}}$ in Eqs. (4) and (6), are stored and represent the baseline input case. For each of a sequence of criticality calculations, KRONOS applies Eq. (4) for nuclides with $n>10$, and Eq. (6) for nuclides with $\mathrm{n} \leq 10$. (The choice of 10 measurements as a cutoff is somewhat arbitrary, although it is based on experience that demonstrates a chi-squared-tested normal distribution with 6-9 measurements.) All fuel nuclide concentrations are modified simultaneously and independently, using a random number generated from a normal distribution when applying Eq. (4), and from a uniform distribution when applying Eq. (6). For models with an axial burnup distribution, nuclide concentrations were modified independently in each axial zone. In each individual criticality calculation, the appropriate input [either a one-dimensional (1-D) CSAS1X or a 3-D CSAS25 model] is prepared based on the configuration specified in the initial input model, but with modified isotopic concentrations. The criticality calculation is executed as a normal SCALE calculation. Once a calculation is completed the resulting output file is parsed to read the calculated eigenvalue, and a new case is generated and submitted for execution. This process is repeated until a specified number of calculations have been completed. 
Table 1. Validation results used in uncertainty analyses

\begin{tabular}{|c|c|c|c|c|c|c|c|c|c|}
\hline Nuclide & $\bar{X}$ & $\mathrm{~s}$ & $\mathrm{n}$ & $\mathrm{T}_{95 / 95}$ & Nuclide & $\bar{X}$ & $\mathrm{~s}$ & $\mathrm{n}$ & $\mathrm{T}_{95 / 95}$ \\
\hline $\mathrm{Am}-241^{a}$ & 1.1420 & 0.176 & 9 & 3.031 & $\mathrm{Am}-243^{a}$ & 1.0491 & 0.066 & 6 & 3.708 \\
\hline $\mathrm{Cm}-242^{a}$ & 1.3916 & 0.087 & 15 & & $\mathrm{Cm}-243^{a}$ & 1.0266 & 0.063 & 9 & 3.031 \\
\hline $\mathrm{Cm}-244^{a}$ & 1.1090 & 0.053 & 15 & & Cs- 133 & 0.9759 & 0.009 & 3 & 7.656 \\
\hline Cs-135 & 0.9471 & 0.029 & 9 & 3.031 & Eu-151 & 0.7584 & 0.033 & 3 & 7.656 \\
\hline Eu-153 & 0.9395 & 0.039 & 3 & 7.656 & Eu-154 & 1.2735 & 0.070 & 9 & 3.031 \\
\hline Eu-155 & 1.3586 & 0.109 & 3 & 7.656 & Gd-154 & 1.0144 & 0.035 & 3 & 7.656 \\
\hline Gd-155 & 1.3586 & 0.109 & 3 & 7.656 & Nd-143 & 1.0000 & 0.005 & 3 & 7.656 \\
\hline Nd-145 & 1.0032 & 0.004 & 3 & 7.656 & Nd-148 & 0.9992 & 0.018 & 16 & \\
\hline $\mathrm{Np}-237^{a}$ & 0.9484 & 0.094 & 13 & & Pm-147 & 1.0170 & 0.042 & 3 & 7.656 \\
\hline $\mathrm{Pu}-238^{a}$ & 1.0338 & 0.077 & 24 & & $\mathrm{Pu}-239^{a}$ & 1.0142 & 0.029 & 38 & \\
\hline $\mathrm{Pu}-240^{a}$ & 1.0030 & 0.027 & 38 & & $\mathrm{Pu}-241^{a}$ & 1.0119 & 0.035 & 38 & \\
\hline $\mathrm{Pu}-242^{a}$ & 0.9875 & 0.064 & 34 & & Sm-147 & 1.0170 & 0.042 & 3 & 7.656 \\
\hline Sm-149 & 1.5095 & 0.406 & 3 & 7.656 & Sm-150 & 1.0018 & 0.050 & 3 & 7.656 \\
\hline $\mathrm{Sm}-151$ & 0.7584 & 0.033 & 3 & 7.656 & $\mathrm{U}-234^{a}$ & 0.9829 & 0.133 & 14 & \\
\hline $\mathrm{U}-235^{a}$ & 1.0104 & 0.035 & 38 & & $\mathrm{U}-236^{a}$ & 1.0132 & 0.048 & 38 & \\
\hline $\mathrm{U}-238^{a}$ & 1.0026 & 0.005 & 32 & & & & & & \\
\hline
\end{tabular}

${ }^{a}$ Nuclides used in actinide-only analysis. 
In addition to the sequence of shuffled-concentration criticality calculations, four additional reference calculations are performed. The first uses nominal isotopics, i.e., the set originally specified in the user-supplied case. The second uses biased isotopics, with the original nominal concentrations corrected to expected values by multiplication by $\bar{X}_{\mathrm{i}}$. The third calculates a maximum value of $k$ using the upper estimate of fissile nuclide concentrations and the lower estimate of non-fissile nuclide concentrations, using the bounding approach described earlier. Finally, a fourth case calculates the minimum value of $k$ in a similar fashion, by minimizing fissile and maximizing non-fissile concentrations.

Note that nuclide concentrations correspond to a specific burnup history, and must be prepared using the same codes and data used to determine the bias $(\overline{\mathrm{X}})$ and uncertainty (s) used in subsequent analysis. In this case, depletion calculations were performed using SAS2H and the SCALE 44-group library, consistent with the results of Table 1. 


\section{PARALLEL PROCESSING}

This section provides an overview of the implementation of parallel processing within KRONOS. It does not provide a detailed description of the logic required for parallel implementation, nor does it describe the MPI-specific calls that are embedded in the KRONOS source code. Reference 9 provides all the detail needed to understand the parallel functionality of KRONOS. This section is merely intended to give an overview of the features of this parallel code to provide a better understanding of the advantages of this type of implementation.

Through the use of calls to MPI in KRONOS, it is possible to run a large number of SCALE calculations in parallel on a distributed network of computational platforms. All of the calculations described in this report were performed using 1000 independent calculations with randomly-varied concentrations, plus the four reference calculations described earlier. Assuming 30 CPU-minutes to perform cross-section processing and KENO analysis for a cask model, 1004 cases would require almost 3 weeks to process on a dedicated CPU. Running in parallel on 20 machines would reduce the execution time to something on the order of 1-2 days, even with competing calculations running on the same machines.

KRONOS is designed to function in a master/slave mode of operation. The single master process is responsible for reading in the initial input, generating a sequence of random numbers, creating each of the 1004 standard SCALE inputs, assigning cases to CPUs as they become available, parsing output from each completed case, and printing results. The only function of a slave processor is to set up a batch file to execute each case, then execute that batch file. The only communication needed between master and slave is the number of the next case to be processed, provided to each slave by the master, and a signal from each slave to the master indicating it has completed a calculation and that it is ready for a new case.

At the beginning of a KRONOS calculation, the "mpirun" command is used to specify the number of processors to use, the names of those machines, and the name of the executable on each machine. Given $\mathrm{N}+1$ processors, the first is designated as the master, and the remaining $\mathrm{N}$ processors function as slaves. After initial setup, the master process provides a starting case to each of the N slave CPUs. It then sits idle and waits for any of the processes to complete. The processes can complete their assigned calculations in any order - once one calculation is complete on a given processor and it signals to the master processor that it is done, this slave processor is assigned the number of the next case to be processed. In this manner, each machine is able to process calculations as fast as it can, without being limited by slower or busier machines. It is possible for one CPU to complete several calculations while a different CPU processes a single case. This process continues until all cases have been provided to the various machines. After this point, when a slave machine completes a calculation, the master process passes a 0 back to the slave, telling it that there are no more cases to process. When all slave processes have returned their final results and terminated, the master process also terminates, completing the KRONOS calculation.

MPI itself is processor independent, so that different versions of KRONOS can be compiled on different computer architectures, and still operate and communicate with the master 
process. All that is necessary for KRONOS to operate on a given machine is the installation of MPI on that machine, as well as the availability of SCALE in its standard location. Because of the extremely small amount of data transmitted between processors (typically just two integers), the network speed between machines is not an issue. For the calculations described here, KRONOS was run on 14 different CPUs, consisting of 9 Compaq Alpha workstations (running OSF 4.0 and 5.0, and a wide range of processor speeds) and 5 IBM RS/6000 workstations. The older IBM machines ran at a much slower speed than most of the Alphas, but were rarely running other calculations and were therefore essentially dedicated. Additionally, because MPI allows more than one process on a single CPU, one CPU served to host both the master process and one of the slave processes, letting the slave process take advantage of the majority of the processing power available on that machine while the master process was idle.

Finally, it is worth mentioning that KRONOS was designed to "play well with others." Because of the number of simultaneous calculations occuring at a given time, and over an extended period of time, KRONOS has the ability to hamper the calculational efforts of other individuals using the same hardware. Therefore, SCALE calculations launched as child processes of each slave process were assigned an execution priority using the unix "nice" command. This allowed other users to utilitize most of the CPU processing power when running at the same time as a slave process on a given machine, but allowed KRONOS to use all available CPU cycles when not in use by others.

The power of parallel processing allowed the study of a number of different burnup states and modeling approximations in a reasonable amount of time. The following section describes the cases studied and the results of those analyses. 


\section{RESULTS}

KRONOS calculations were performed for 30 different burnup/composition/modeling combinations. Table 2 provides a summary of the different analysis types and the uncertainty results associated with each set of calculations. Calculations were performed for two geometric configurations. The first was a generic burnup credit cask design for ongoing burnup credit studies. ${ }^{10}$ This model consists of a 32 PWR assembly cask design fully loaded with Westinghouse $17 \times 17$ OFA fuel assemblies. The second model type was a simple pin-cell model, representing an infinite lattice of fuel pins of the Westinghouse $17 \times 17$ OFA design. Calculations with the cask model were performed using KENO V.a, while pin-cell calculations were performed using both KENO V.a and XSDRNPM. KENO V.a is a 3-D criticality code using a Monte Carlo simulation of neutron transport; XSDRNPM is a 1-D deterministic code for criticality calculations. For the KENO V.a pin-cell calculations, a full-length rod was assumed, with reflective boundary conditions on the cell boundaries and vacuum boundary conditions on the ends of the rods. Sample inputs for all three model/code calculations are included in Appendix B.

Calculations were also performed for isotopic concentrations predicted at burnups of 20, 40 , and $60 \mathrm{GWd} / \mathrm{MTU}$, both with and without fission products present. In each of the 3-D KENO V.a models, calculations were performed (1) assuming an axial burnup profile with a mean corresponding to nominal burnups listed earlier, using 18 uniform-height axial zones, ${ }^{2}$ and (2) for a single uniform burnup. Because of the 1-D nature of XSDRNPM calculations, axiallyvarying concentrations cannot be easily modeled, and were not analyzed.

As described earlier, KRONOS first performs four calculations with specific isotopic sets, to obtain nominal, best-estimate, minimum and maximum values of $k$ for the given case; 1000 cases were then calculated with randomly varying isotopic concentrations derived using the methods described earlier. The last two columns of Table 2 provide the mean value of $k$ and the corresponding uncertainty associated with this value. The KRONOS standard deviation given in the last column characterizes the distribution of the set of calculated $k$ values around the mean, and represents the uncertainty in the mean value of $k$ as a result of isotopic uncertainties. This is different from the uncertainty associated with the calculation of each individual value of $k$. The uncertainty in the prediction of each eigenvalue for the individual Monte Carlo calculations is not listed in Table 2. This individual case uncertainty is a factor related to the number of histories run. Each KENO calculation was based on 1100 generations of neutrons, with 1000 neutrons per generation, and the first 100 generations skipped, or 1,000,000 total neutron histories. This uncertainty value varied case to case, but was on the order of 0.0007 , and in no case was it larger than 0.0010. To avoid confusion, it is noted that the remainder of this report focuses on the uncertainty in $k$ arising from uncertainty in isotopic concentrations, where the standard deviation is a measure of the variability in $k$ as a function of isotopic variations. Individual uncertainties associated with each calculation are small with respect to isotopic uncertainty effects, and are not considered further. 
Table 2. Results of KRONOS calculations for various configurations and burnups.

\begin{tabular}{|c|c|c|c|c|c|c|c|c|c|c|c|}
\hline \multirow[b]{2}{*}{ Case No. } & \multirow[b]{2}{*}{$\begin{array}{l}\text { Model } \\
\text { Type }\end{array}$} & \multirow[b]{2}{*}{$\begin{array}{l}\text { Criticality } \\
\text { Code }\end{array}$} & \multirow[b]{2}{*}{$\begin{array}{c}\text { Burnup } \\
\text { (GWd/MTU) }\end{array}$} & \multirow{2}{*}{$\begin{array}{c}\text { Fission } \\
\text { Products } \\
\text { Included }\end{array}$} & \multirow{2}{*}{$\begin{array}{c}\text { Axial } \\
\text { Burnup } \\
\text { Profile } \\
\text { Included }\end{array}$} & \multicolumn{5}{|c|}{$\begin{array}{l}\text { Neutron Multiplcation Factor } \\
(k)\end{array}$} & \multirow{2}{*}{$\begin{array}{l}\text { KRONOS } \\
\text { Standard } \\
\text { Deviation }\end{array}$} \\
\hline & & & & & & Nominal & $\begin{array}{c}\text { Best } \\
\text { Estimate }\end{array}$ & Minimum & Maximum & $\begin{array}{c}\text { KRONOS } \\
\text { (mean) }\end{array}$ & \\
\hline 1 & Cask & KENO V.a & 20 & Yes & Yes & 0.9777 & 0.9754 & 0.9109 & 1.0139 & 0.9749 & 0.0099 \\
\hline 2 & Cask & KENO V.a & 40 & Yes & Yes & 0.8742 & 0.8699 & 0.8057 & 0.9110 & 0.8673 & 0.0147 \\
\hline 3 & Cask & KENO V.a & 60 & Yes & Yes & 0.7900 & 0.7856 & 0.7229 & 0.8288 & 0.7835 & 0.0160 \\
\hline 4 & Cask & KENO V.a & 20 & No & Yes & 1.0375 & 1.0394 & 1.0168 & 1.0643 & 1.0406 & 0.0025 \\
\hline 5 & Cask & KENO V.a & 40 & No & Yes & 0.9517 & 0.9544 & 0.9249 & 0.9800 & 0.9536 & 0.0035 \\
\hline 6 & Cask & KENO V.a & 60 & No & Yes & 0.8829 & 0.8850 & 0.8553 & 0.9124 & 0.8851 & 0.0042 \\
\hline 7 & Cask & KENO V.a & 20 & Yes & No & 0.9739 & 0.9698 & 0.9032 & 1.0121 & 0.9658 & 0.0258 \\
\hline 8 & Cask & KENO V.a & 40 & Yes & No & 0.8304 & 0.8232 & 0.7557 & 0.8697 & 0.8196 & 0.0269 \\
\hline 9 & Cask & KENO V.a & 60 & Yes & No & 0.7157 & 0.7118 & 0.6468 & 0.7591 & 0.7076 & 0.0257 \\
\hline 10 & Cask & KENO V.a & 20 & No & No & 1.0334 & 1.0373 & 1.0117 & 1.0595 & 1.0363 & 0.0067 \\
\hline 11 & Cask & KENO V.a & 40 & No & No & 0.9184 & 0.9200 & 0.8863 & 0.9524 & 0.9209 & 0.0067 \\
\hline 12 & Cask & KENO V.a & 60 & No & No & 0.8242 & 0.8254 & 0.7870 & 0.8616 & 0.8257 & 0.0074 \\
\hline
\end{tabular}


Table 2 (continued)

\begin{tabular}{|c|c|c|c|c|c|c|c|c|c|c|c|}
\hline \multirow[b]{2}{*}{ Case No. } & \multirow[b]{2}{*}{$\begin{array}{l}\text { Model } \\
\text { Type }\end{array}$} & \multirow[b]{2}{*}{$\begin{array}{l}\text { Criticality } \\
\text { Code }\end{array}$} & \multirow[b]{2}{*}{$\begin{array}{c}\text { Burnup } \\
(\mathrm{GWd} / \mathrm{MTU})\end{array}$} & \multirow{2}{*}{$\begin{array}{l}\text { Fission } \\
\text { Products } \\
\text { Included }\end{array}$} & \multirow{2}{*}{$\begin{array}{c}\text { Axial } \\
\text { Burnup } \\
\text { Profile } \\
\text { Included }\end{array}$} & \multicolumn{5}{|c|}{$\begin{array}{l}\text { Neutron Multiplcation Factor } \\
(k)\end{array}$} & \multirow{2}{*}{$\begin{array}{c}\text { KRONOS } \\
\text { Standard } \\
\text { Deviation }\end{array}$} \\
\hline & & & & & & Nominal & $\begin{array}{c}\text { Best } \\
\text { Estimate }\end{array}$ & Minimum & Maximum & $\begin{array}{l}\text { KRONOS } \\
\text { (mean) }\end{array}$ & \\
\hline 13 & Pin-cell & KENO V.a & 20 & Yes & Yes & 1.2251 & 1.2176 & 1.1360 & 1.2636 & 1.2207 & 0.0116 \\
\hline 14 & Pin-cell & KENO V.a & 40 & Yes & Yes & 1.0852 & 1.0756 & 0.9959 & 1.1260 & 1.0741 & 0.0192 \\
\hline 15 & Pin-cell & KENO V.a & 60 & Yes & Yes & 0.9768 & 0.9672 & 0.8880 & 1.0196 & 0.9645 & 0.0208 \\
\hline 16 & Pin-cell & KENO V.a & 20 & No & Yes & 1.3174 & 1.3196 & 1.2921 & 1.3435 & 1.3189 & 0.0015 \\
\hline 17 & Pin-cell & KENO V.a & 40 & No & Yes & 1.2076 & 1.2071 & 1.1750 & 1.2384 & 1.2072 & 0.0034 \\
\hline 18 & Pin-cell & KENO V.a & 60 & No & Yes & 1.1220 & 1.1221 & 1.0856 & 1.1587 & 1.1224 & 0.0042 \\
\hline 19 & Pin-cell & KENO V.a & 20 & Yes & No & 1.2277 & 1.2193 & 1.1365 & 1.269 & 1.2144 & 0.0351 \\
\hline 20 & Pin-cell & KENO V.a & 40 & Yes & No & 1.0498 & 1.0393 & 0.9533 & 1.0971 & 1.035 & 0.0375 \\
\hline 21 & Pin-cell & KENO V.a & 60 & Yes & No & 0.9124 & 0.9021 & 0.8195 & 0.9622 & 0.8981 & 0.0361 \\
\hline 22 & Pin-cell & KENO V.a & 20 & No & No & 1.3412 & 1.3159 & 1.3048 & 1.2864 & 1.3145 & 0.0063 \\
\hline 23 & Pin-cell & KENO V.a & 40 & No & No & 1.1805 & 1.1813 & 1.1407 & 1.2199 & 1.1811 & 0.0079 \\
\hline 24 & Pin-cell & KENO V.a & 60 & No & No & 1.0699 & 1.0723 & 1.0244 & 1.1185 & 1.0714 & 0.0093 \\
\hline 25 & Pin-cell & XSDRNPM & 20 & Yes & $\mathrm{N} / \mathrm{A}$ & 1.2301 & 1.2217 & 1.1379 & 1.2711 & 1.2168 & 0.0351 \\
\hline
\end{tabular}


Table 2 (continued)

\begin{tabular}{|c|c|c|c|c|c|c|c|c|c|c|c|}
\hline \multirow[b]{2}{*}{ Case No. } & \multirow[b]{2}{*}{$\begin{array}{l}\text { Model } \\
\text { Type }\end{array}$} & \multirow[b]{2}{*}{$\begin{array}{l}\text { Criticality } \\
\text { Code }\end{array}$} & \multirow[b]{2}{*}{$\begin{array}{c}\text { Burnup } \\
\text { (GWd/MTU) }\end{array}$} & \multirow{2}{*}{$\begin{array}{c}\text { Fission } \\
\text { Products } \\
\text { Included }\end{array}$} & \multirow{2}{*}{$\begin{array}{c}\text { Axial } \\
\text { Burnup } \\
\text { Profile } \\
\text { Included }\end{array}$} & \multicolumn{5}{|c|}{$\begin{array}{l}\text { Neutron Multiplcation Factor } \\
(k)\end{array}$} & \multirow{2}{*}{$\begin{array}{l}\text { KRONOS } \\
\text { Standard } \\
\text { Deviation }\end{array}$} \\
\hline & & & & & & Nominal & $\begin{array}{c}\text { Best } \\
\text { Estimate }\end{array}$ & Minimum & Maximum & $\begin{array}{l}\text { KRONOS } \\
\text { (mean) }\end{array}$ & \\
\hline 26 & Pin-cell & XSDRNPM & 40 & Yes & $\mathrm{N} / \mathrm{A}$ & 1.0514 & 1.0416 & 0.9548 & 1.0981 & 1.0367 & 0.0375 \\
\hline 27 & Pin-cell & XSDRNPM & 60 & Yes & $\mathrm{N} / \mathrm{A}$ & 0.9142 & 0.9040 & 0.8206 & 0.9638 & 0.8995 & 0.0362 \\
\hline 28 & Pin-cell & XSDRNPM & 20 & No & N/A & 1.3162 & 1.3173 & 1.2889 & 1.3436 & 1.3171 & 0.0065 \\
\hline 29 & Pin-cell & XSDRNPM & 40 & No & $\mathrm{N} / \mathrm{A}$ & 1.1827 & 1.1834 & 1.1430 & 1.2219 & 1.1834 & 0.0078 \\
\hline 30 & Pin-cell & XSDRNPM & 60 & No & N/A & 1.0726 & 1.0733 & 1.0254 & 1.1201 & 1.0735 & 0.0091 \\
\hline
\end{tabular}


Many conclusions and interpretations are possible when the results of Table 2 are compared and contrasted. Further insights are possible by looking at the set of 1000 eigenvalues as a whole for each of the burnup cases. The following subsections attempt to describe some of the most significant observations made in the study of these results.

\subsection{Convergence}

Both the KRONOS neutron multiplication factor and uncertainty are converged values, indicating that a sufficient number of cases have been run that the distribution of $k$ values is a close approximation to the form of the distribution that would be seen for an infinite number of cases. All cases of Table 2 were run using 1000 individual criticality calculations. This number was picked based on early studies with KRONOS that indicated that the mean value of $k$ and its standard deviation appeared to converge within the first 500 cases. Figure 1 illustrates the mean value of $k$ as a function of the number of isotopically varied criticality calculations run, for cases 3, 6, 9 and 12. These cases are cask models with a burnup of $60 \mathrm{GWd} / \mathrm{MTU}$. Figure 2 shows the convergence of the standard deviation, $\mathrm{s}$, with an increasing number of cases.

Although it is difficult to see because of the different relative y-axis scales between the two figures, it can be shown that the mean value of $k, \overline{\mathrm{k}}$, converges much more rapidly than the standard deviation, but for all cases both $\overline{\mathrm{k}}$ and $\mathrm{s}$ are converged within 800 calculations. The high burnup $60 \mathrm{GWd} / \mathrm{MTU}$ case was selected because it exhibits the slowest convergence. This is not surprising, since the highest burnup cases have the largest fraction of fission products and higher-order actinides relative to the uranium nuclides. From Table 1, it is clear that the uncertainty for these nuclides is larger than for the uranium isotopes. Thus the higher the burnup, the more variability there is in the constituent nuclides, and the slower the convergence.

Figure 2 also shows that the case with fission products included and with a uniform axial burnup (case 9 of Table 2) is the slowest to converge. This behavior is also seen for the lower burnup cases. Convergence is delayed in part by the larger uncertainty associated with fission products (see Table 1). This effect is compounded by the fact that the uniform burnup profile over-weights the importance of fission products by forcing a cosine-shaped fission density profile, rather than the physical reality where the fission density is highest away from the axial center of the fuel, where fission product inventories are smaller. This phenomenon is described in more detail in Ref. 5. 


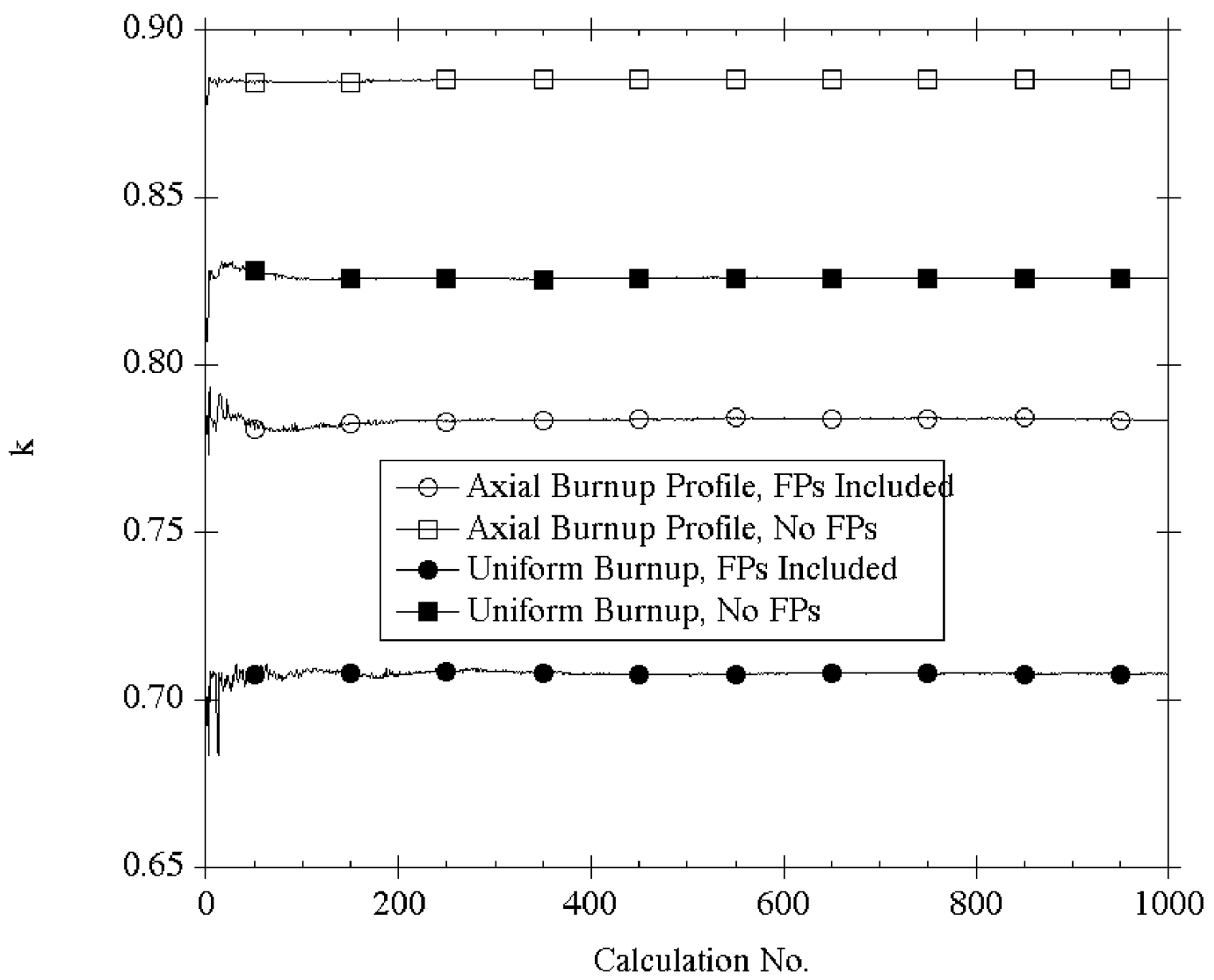

Fig. 1. Convergence of mean value of $k$ for $60 \mathrm{GWd} / \mathrm{MTU}$ cask models. 


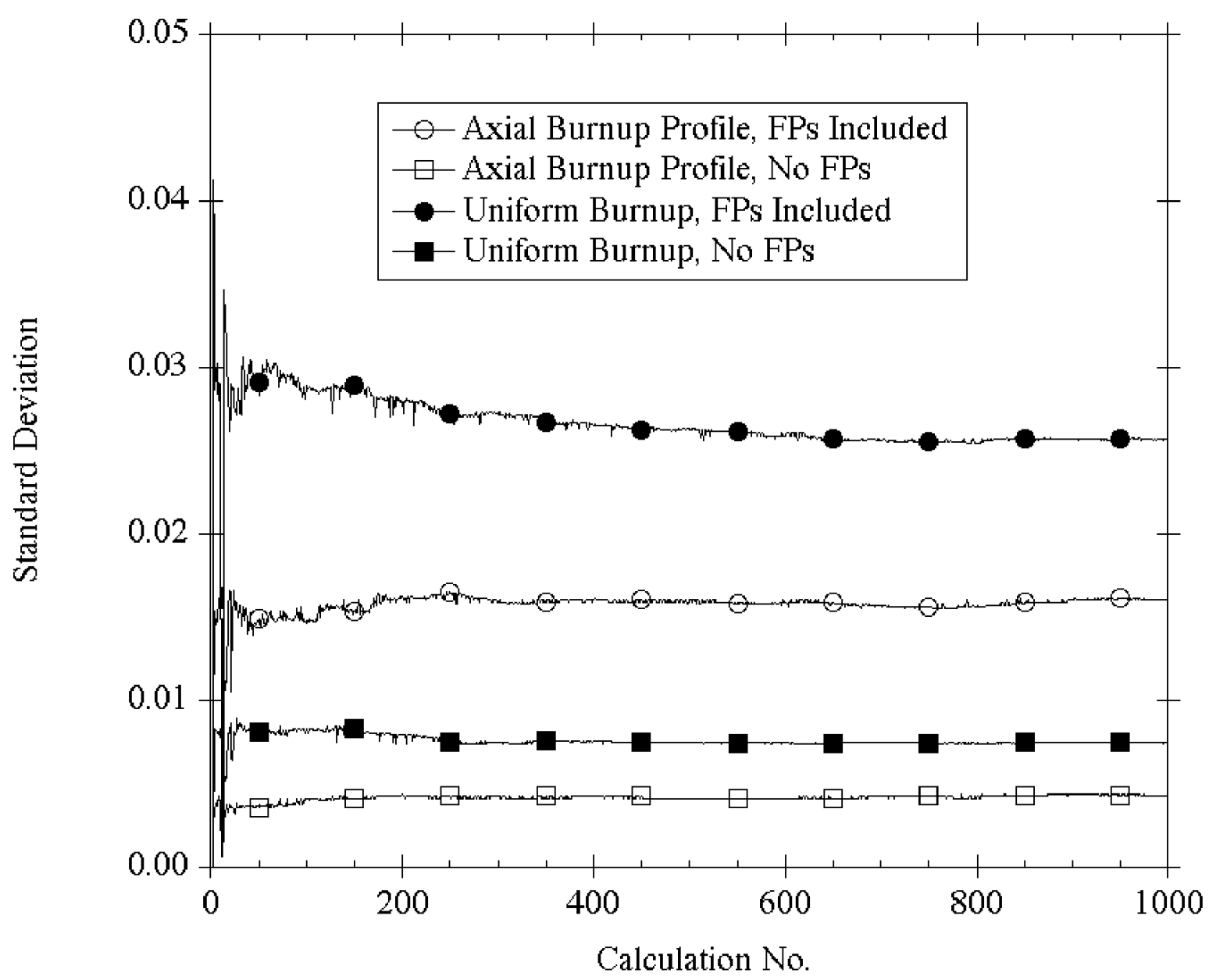

Fig. 2. Convergence of population standard deviation for $60 \mathrm{GWd} / \mathrm{MTU}$ cask models.

\subsection{Distribution of Eigenvalues}

As seen in Figure 3, the distribution of $k$ values from Case 1 is in the form of a normal distribution, with the largest number of observances falling close to the mean and dropping off to very few cases found outside of a $3 s$ band around the mean $(0.9452-1.0046)$. In fact, the upper bound calculated based on "bounding" isotopic concentrations for this case is 1.0139 is $4 s$ from the mean value, demonstrating the conservatism of such an approach. 


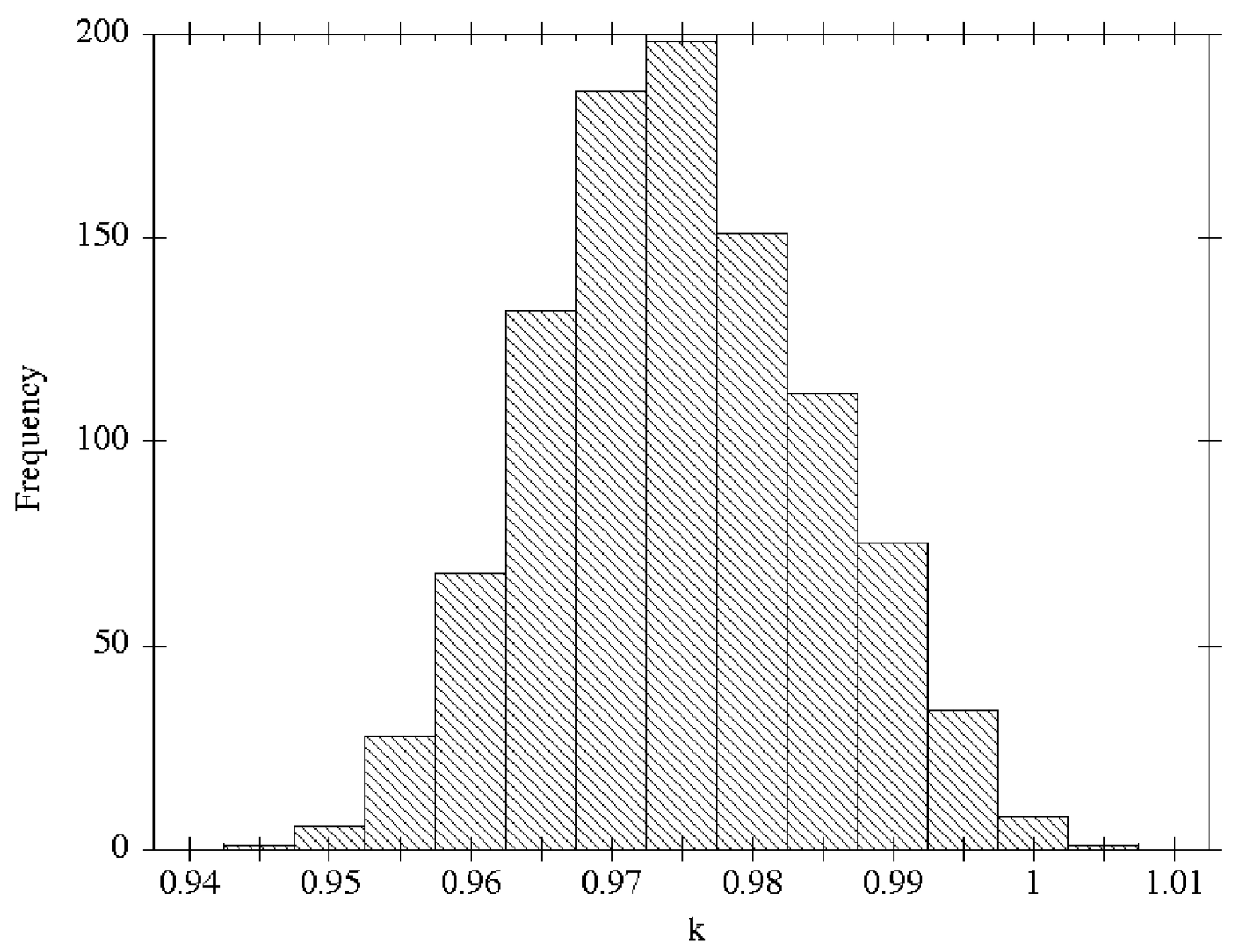

Fig. 3. Distribution of $k$ values for Case $1,20 \mathrm{GWd} / \mathrm{MTU}$.

Figures 4 and 5 show the distribution of eigenvalues obtained for the same model at higher burnups. Note that as the burnup increases, the shape of the profile begins to depart slightly from a normal distribution, as it becomes more weighted on the lower tail region. The effect is due to the larger uncertainties associated with certain fission products. As the fission products build up, they begin to have a more pronounced effect on the system eigenvalues. However, although fission concentrations are allowed to vary randomly in a form prescribed by Eqs. (4) or (6), there is a physical lower limit of zero for a concentration. When the random variation in the nuclide concentration is less than zero, the concentration is set to zero. Thus, for extreme cases where the uncertainty range is greater than the calculated concentration, the effective worth of the absorber is more heavily weighted, resulting in a shift of the distribution toward the left tail. However, the effect is relatively small. 


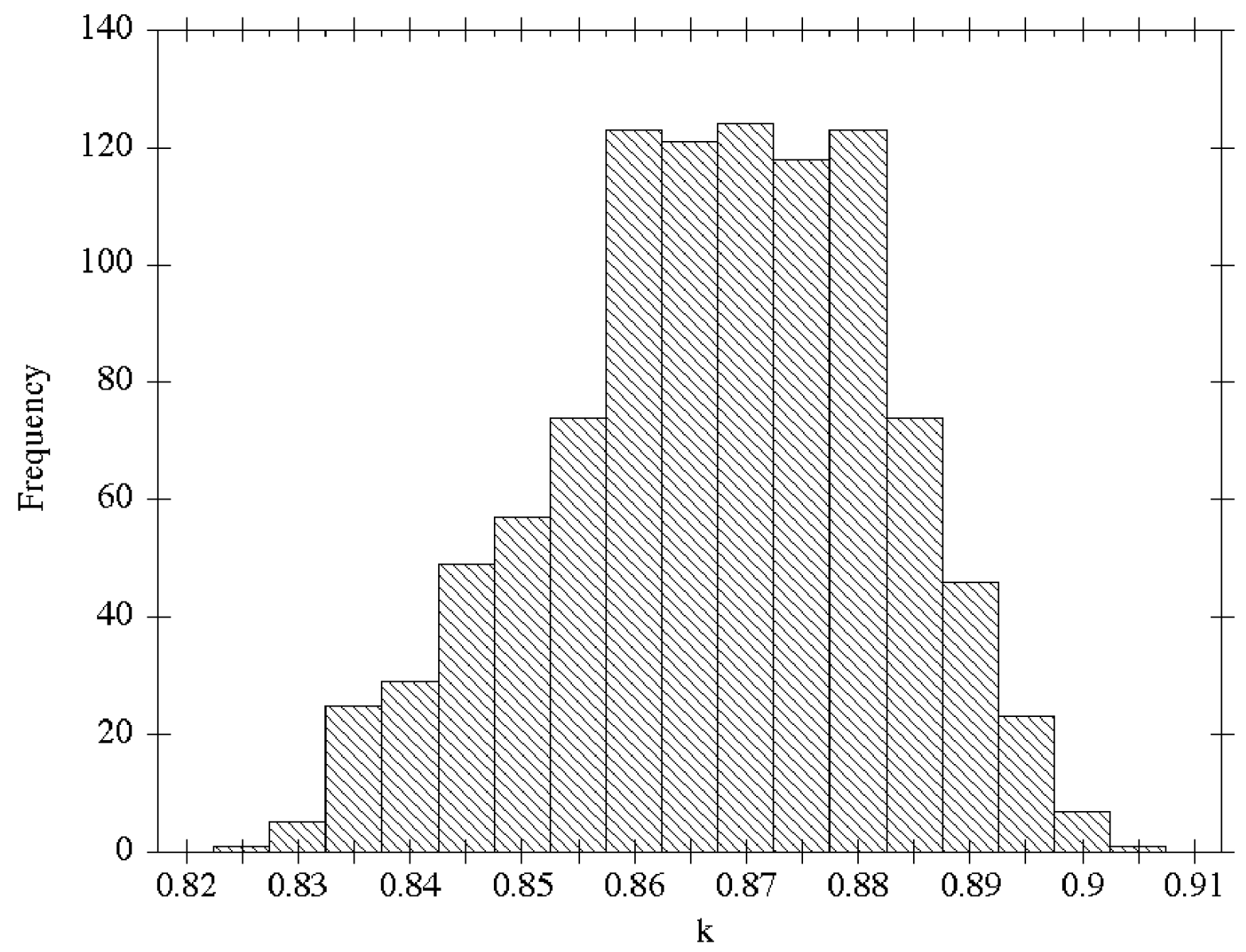

Fig. 4. Distribution of $k$ values for Case 2, $40 \mathrm{GWd} / \mathrm{MTU}$. 


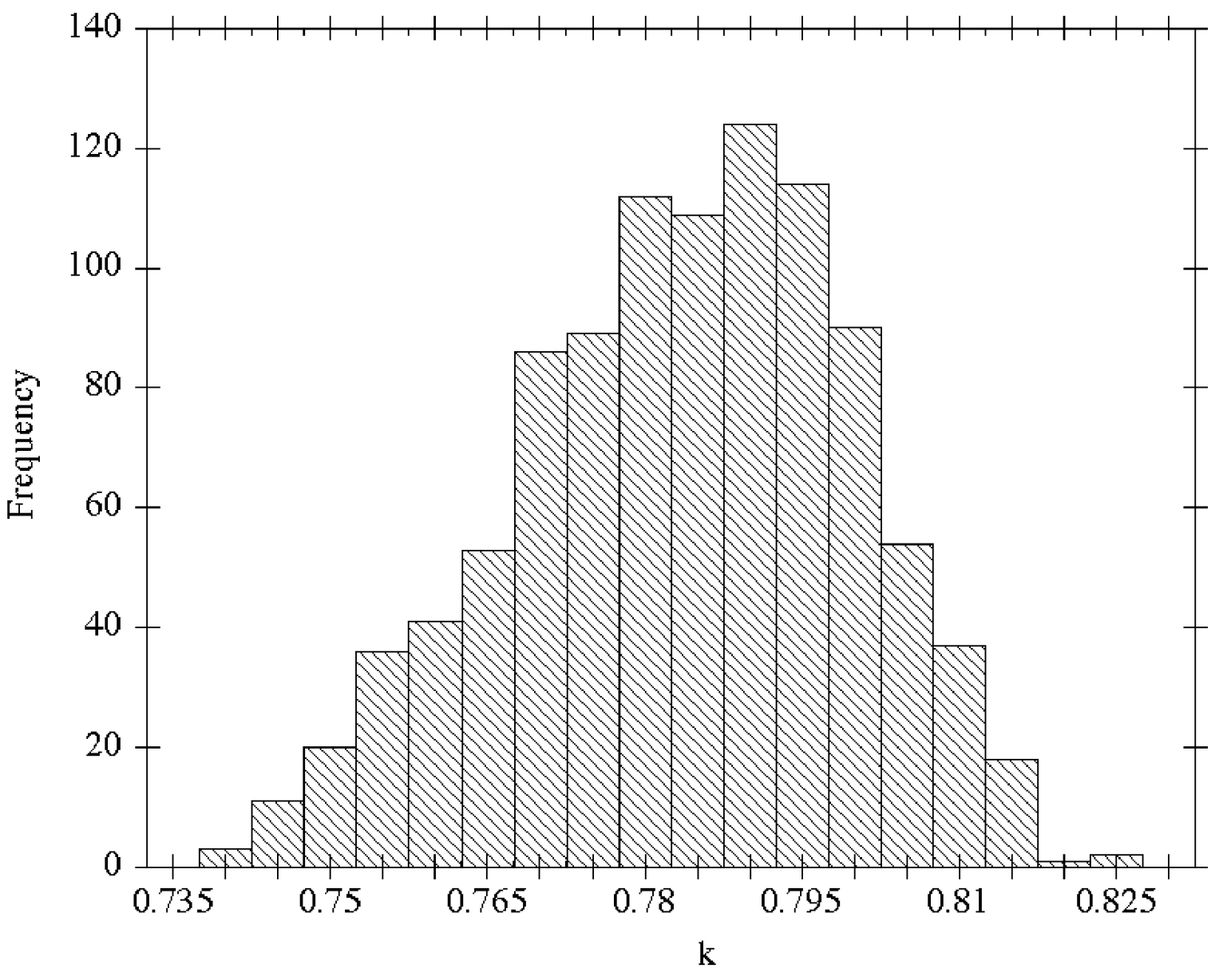

Fig. 5. Distribution of $k$ values for Case 3, $60 \mathrm{GWd} / \mathrm{MTU}$. 


\subsection{Actinide-Only vs. "Full” Burnup Credit}

Current directions for first-generation burnup credit implementation for transportation casks are based on taking only partial credit for reactivity reduction due only to primary actinides for which radiochemical assay data are available. The term "full burnup credit" has often been applied to approaches such as that currently being considered for disposal applications where credit is taken for a set of the most important fission product absorbers. The word "full" is a misnomer in the sense that this approach takes credit for only a small subset of fission product nuclides, ignoring a large number of lesser absorbers that as a whole amount to roughly $20 \%$ of the total fission product worth in burned fuel. ${ }^{5}$ In general, fission product biases and uncertainties are larger than those of actinides, due both to the availability of fewer fission product measurements and weaknesses in the accuracy of fission product cross-section data. This work shows the different responses of $k$ due to the two modeling assumptions.

Different studies have applied different sets of nuclides in both actinide-only and full burnup credit modeling. The current work makes no attempt to evaluate different sets of nuclides. Instead, these calculations were performed using all nuclides for which radiochemical assay data are available, as listed in Table 1. Actinide-only calculations were performed with the full contingent of actinides listed in the table.

Table 3 provides a comparison of the differences between the mean or expected value of $k$ (KRONOS $k$ ) for corresponding cases with and without fission products. The table also shows the difference in the uncertainty between the two nuclide sets. The $\Delta k$ results are consistent with the known behavior of fission products: As would be expected, the results show that reactivity worth becomes increasingly negative with increasing burnup, as fission product inventories increase. Trends in these results are more easily seen in Fig. 6, which shows the reactivity decrease with increasing burnup for each of the model types. This plot also allows several observations (not new to this work, but certainly worth noting):

- Fission products are worth less in a model that uses an axially varying burnup profile instead of the assumption of axially uniform burnup. This is due to the shift of the neutron flux away from the most highly poisoned axial center with increasing burnup; this shift does not occur when an (aphysical) uniform burnup is assumed.

- Fission products are worth less in a cask model than in an infinite lattice. This is due to the presence of intra-assembly boron plates in the cask, which remove thermal neutrons and thereby reduce the effectiveness of fission products as absorbers.

- The worth of fission products in a simple 1-D pin-cell model is almost identical to that in a 3-D infinite lattice, even though the 3-D model has axial leakage.

- Fission product worth (known to be zero at beginning of life) increases more rapidly early in life and increases less rapidly at higher burnups. This may be due to increased competition for neutrons at higher burnups due to high concentrations of poisons. 
Table 3. Reactivity worth of fission products and associated uncertainties

\begin{tabular}{|c|c|c|c|c|c|c|}
\hline Case nos. & Model Type & Criticality Code & $\begin{array}{c}\text { Burnup } \\
\text { (GWd/MTU) }\end{array}$ & $\begin{array}{c}\text { Axial } \\
\text { Burnup } \\
\text { Profile } \\
\text { Included }\end{array}$ & $\begin{array}{c}\Delta k \\
\left(\mathrm{k}_{\text {full }}-\mathrm{k}_{\mathrm{AO}}\right)\end{array}$ & $\begin{array}{c}\Delta s \\
\left(s_{\text {full }}-s_{\mathrm{AO}}\right)\end{array}$ \\
\hline $1 \& 4$ & Cask & KENO V.a & 20 & Yes & -0.0657 & 0.0074 \\
\hline $2 \& 5$ & Cask & KENO V.a & 40 & Yes & -0.0863 & 0.0112 \\
\hline $3 \& 6$ & Cask & KENO V.a & 60 & Yes & -0.1016 & 0.0118 \\
\hline $7 \& 10$ & Cask & KENO V.a & 20 & No & -0.0705 & 0.0191 \\
\hline $8 \& 11$ & Cask & KENO V.a & 40 & No & -0.1013 & 0.0202 \\
\hline $9 \& 12$ & Cask & KENO V.a & 60 & No & -0.1181 & 0.0183 \\
\hline $13 \& 16$ & Pin-cell & KENO V.a & 20 & Yes & -0.0982 & 0.0101 \\
\hline $14 \& 17$ & Pin-cell & KENO V.a & 40 & Yes & -0.1331 & 0.0158 \\
\hline $15 \& 18$ & Pin-cell & KENO V.a & 60 & Yes & -0.1579 & 0.0166 \\
\hline $19 \& 22$ & Pin-cell & KENO V.a & 20 & No & -0.1001 & 0.0288 \\
\hline $20 \& 23$ & Pin-cell & KENO V.a & 40 & No & -0.1461 & 0.0296 \\
\hline $21 \& 24$ & Pin-cell & KENO V.a & 60 & No & -0.1733 & 0.0268 \\
\hline $25 \& 28$ & Pin-cell & XSDRNPM & 20 & $\mathrm{~N} / \mathrm{A}$ & -0.1003 & 0.0286 \\
\hline $26 \& 29$ & Pin-cell & XSDRNPM & 40 & $\mathrm{~N} / \mathrm{A}$ & -0.1467 & 0.0297 \\
\hline $27 \& 30$ & Pin-cell & XSDRNPM & 60 & N/A & -0.1740 & 0.0271 \\
\hline
\end{tabular}




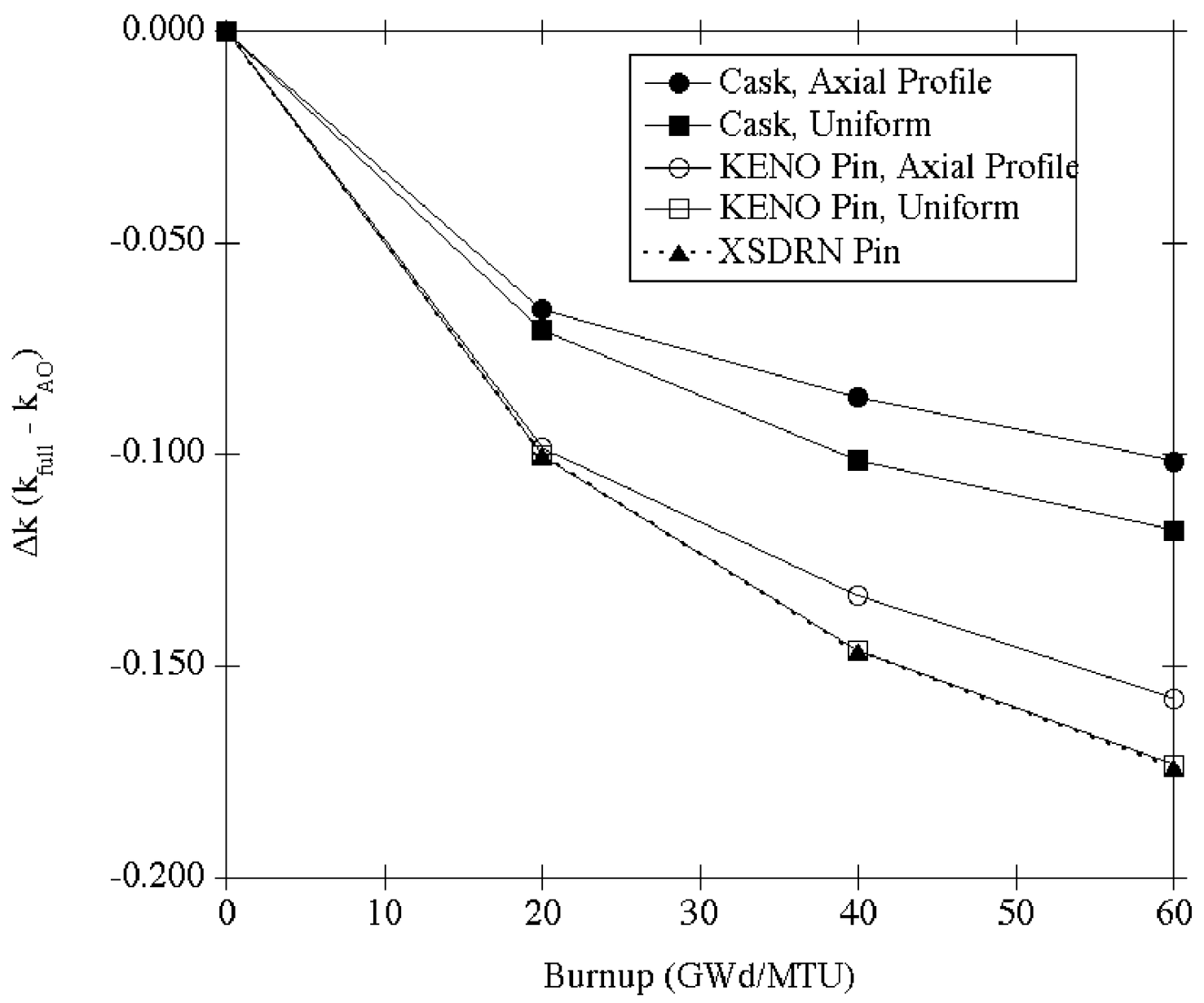

Fig. 6. Fission product reactivity worth as a function of burnup.

None of the above results are unique to the capabilities of KRONOS, and could be determined from a single set of calculations for each model type (e.g., nominal or best estimate results listed in Table 2). More interesting therefore is the behavior of the uncertainty associated with the neutron multiplication factor as a function of the nuclide set applied in a model. The last column of Table 3 shows the difference in the uncertainty in $k$ as a function of the nuclide set modeled. This effectively shows the component of uncertainty due to fission products alone: $\Delta s$, the difference in the net uncertainty between cases with and without fission products, is always positive. These results are shown graphically in Fig. 7. Again, a list of observations is made:

- The uncertainty due to fission products is lower in a cask model than in a pin cell model. This is consistent with the fact that fission products themselves are worth less in a cask model, as discussed earlier.

- The component of uncertainty due to fission product contributions is greater when a uniform axial burnup is assumed. As indicated in the previous discussion, the uniform profile 
over-weights the worth of fission products relative to a distributed burnup profile. As a result, the fission product uncertainty is also amplified.

- In a cask model, fission product uncertainty increases with burnup. This would be expected, since fission product inventories are increasing with burnup.

- In contrast, for pin-cell models although fission product uncertainty increases with burnup initially, this trend reverses as fission product uncertainty decrease at a faster rate as burnup proceeds. This trend is consistent whether an axial burnup profile or a uniform burnup approximation is used. The reason for this behavior is unknown and will require further study.

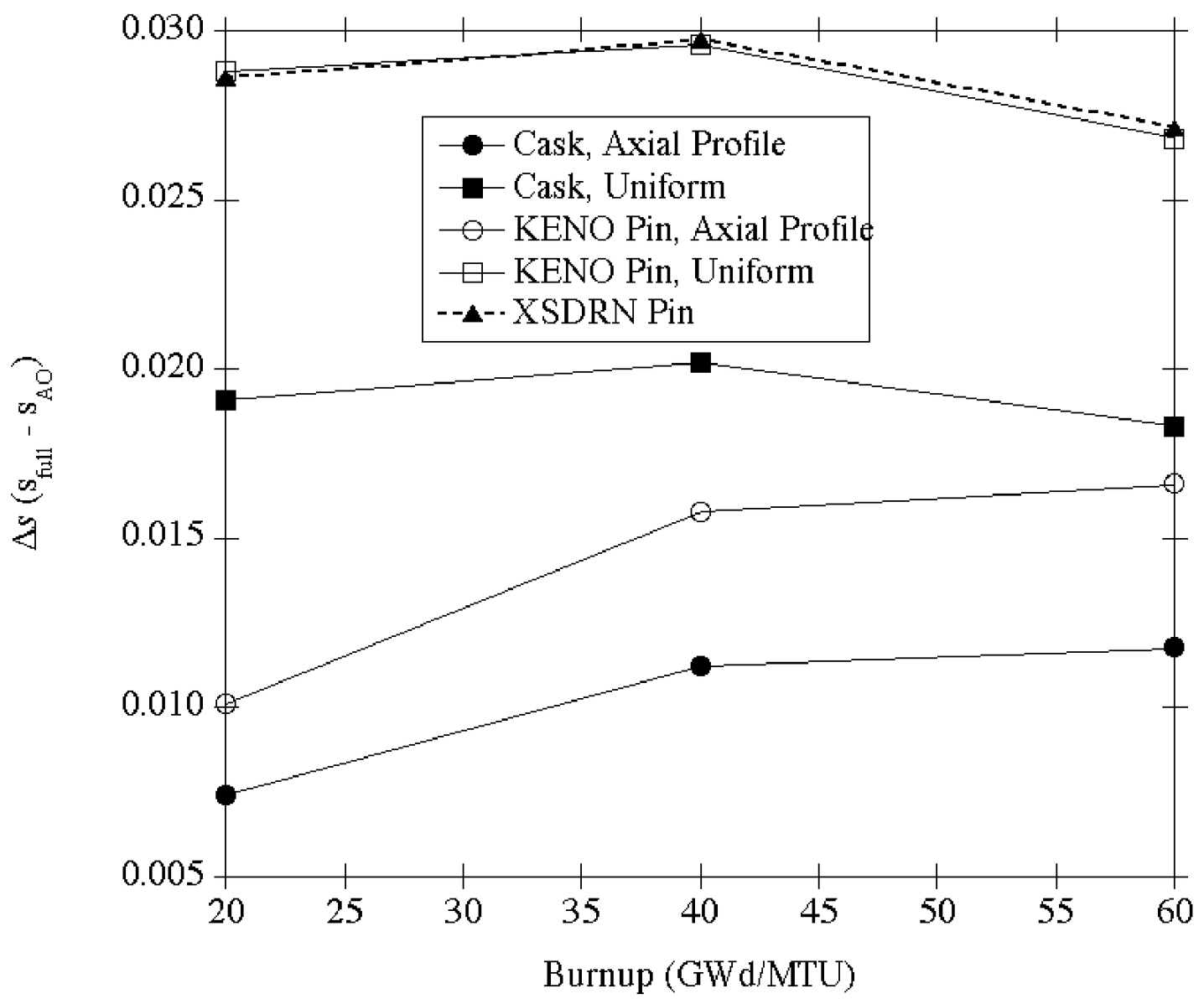

Fig. 7. Uncertainty due to fission products as a function of burnup.

\subsection{Conservatism of Bounding Approach}

Given the large number of criticality calculations performed for each 30 cases studied, it is possible to generate a statistical probability plot for a normal distribution. Figures 8 and 9 
show probability plots generated from the results of each of the three burnups. Figure 8 shows the statistical plot for KENO V.a cask models with actinides and fission products (i.e., cases 13). Similarly, Fig. 9 shows the same analysis for the actinide-only cases (cases 4-6). Each plot shows the probability distribution functions for the range of results obtained for 1000 calculations at each burnup. For a given value of $k$, the plot shows the probability that this value will bound another $k$ value calculated from the distribution. $\mathrm{K}_{\max }$ is the bounding value of $\mathrm{k}$ given in Table 2, obtained using ultraconservative assumptions.

As an example, consider the $20 \mathrm{GWd} / \mathrm{MTU}$ line in Fig. 8. Assuming a desired limit of 0.98 for $k$ in the cask, 0.98 corresponds to a point on the curve at approximately $90 \%$ on the $\mathrm{x}$-ordinate. This indicates that $10 \%$ of the possible isotopic configurations for this burnup would result in a value of $k$ larger than 0.98 . A limit of 0.95 would be met with roughly a $0.5 \%$ probability, i.e., $99.5 \%$ of possible isotopic distributions would result in cask $k$ values of $\geq 0.95$. Basically, these results tell us that for $4 \mathrm{wt} \%$ fuel with a $20 \mathrm{GWd} / \mathrm{MTU}$ burnup, a sufficiently subcritical loading is not possible in the analyzed cask design. This is consistent with the bounding approach, which gives a maximum $k$ value of 1.0139 (well over a 0.95 upper limit).

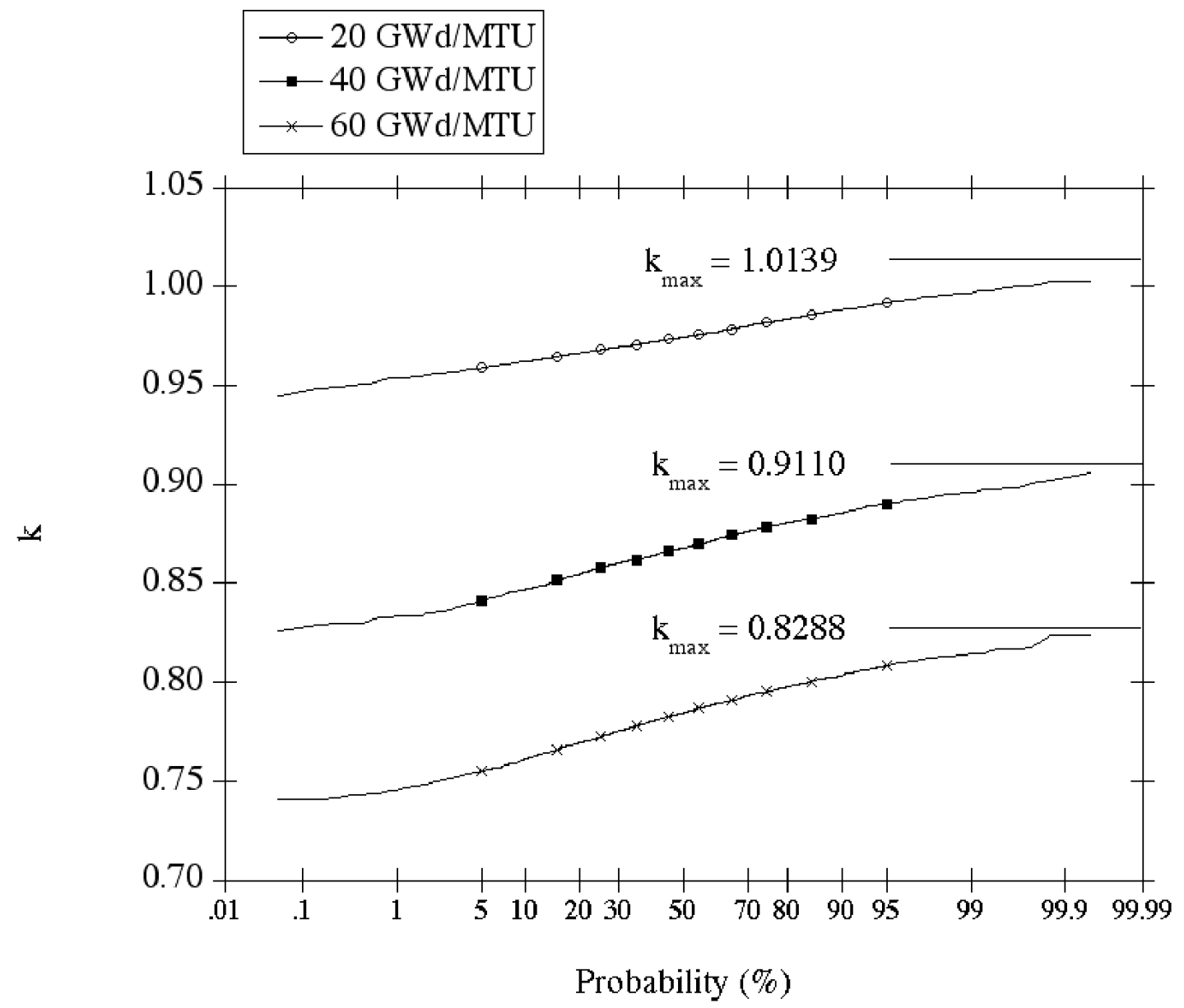

Fig. 8. Probability plot for KENO cask calculations, actinides + fission products. 


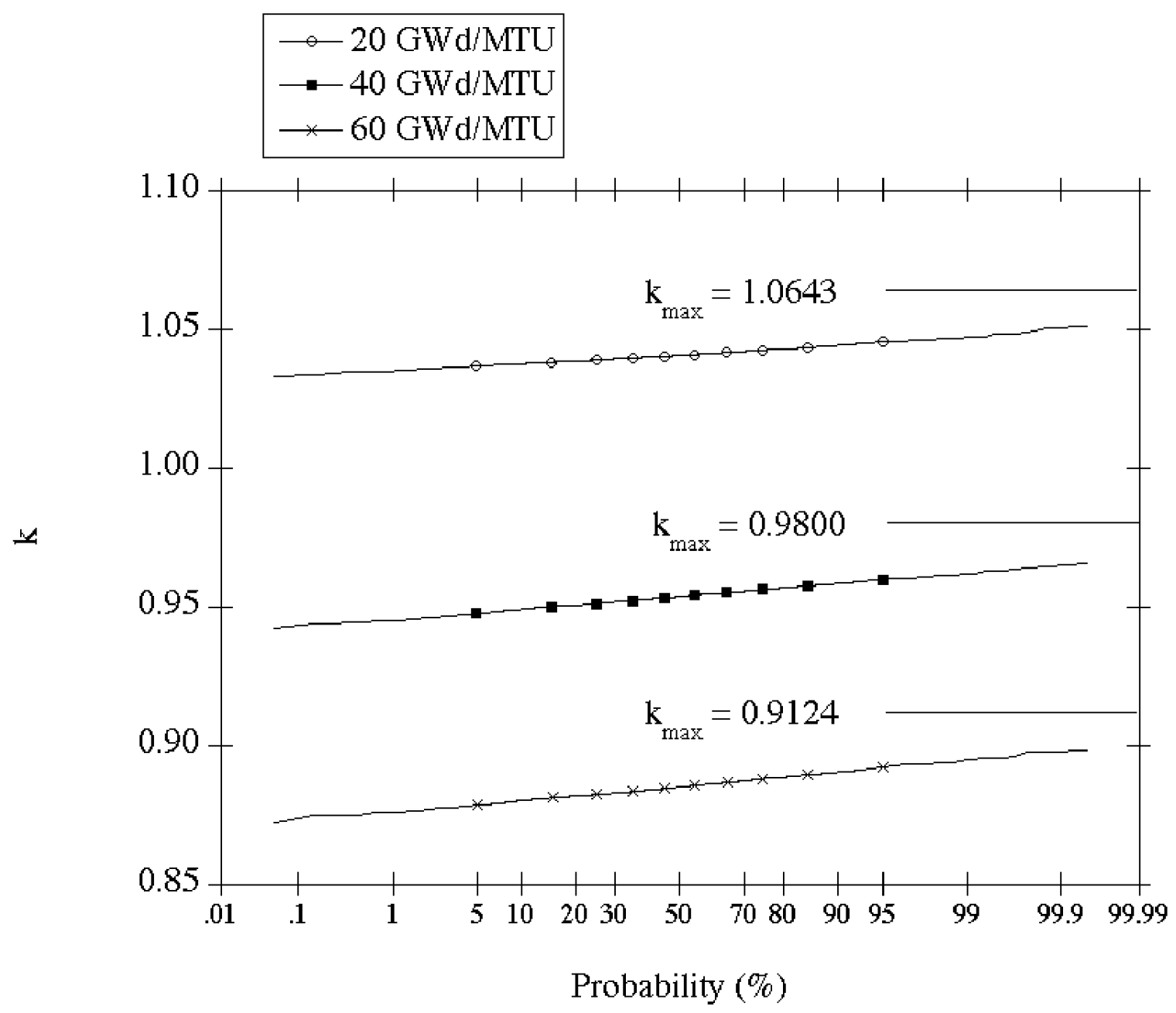

Fig. 9. Probability plot for KENO cask calculations, actinides only.

It is worth noting that the probability distribution function for a normal distribution should be a straight line on a linear-log plot. The results plotted in Fig. 9 are very linear, indicating a normal distribution. The results are linear at low burnup Fig. 8, but departs from linear at the ends as burnup increases. This is consistent with the findings discussed earlier and illustrated in Figs. 3-5, resulting from a non-normal distribution of some nuclides.

Each of the figures shows the value of $\mathrm{k}_{\max }$ calculated for each model and each burnup. Note that in Fig. 8, the full (actinide + fission product) burnup credit cases have a $\mathrm{k}_{\max }$ value corresponding to the 99.9 to $99.99 \%$ percentile. Such a high probability exceeds that assumed for the analysis of a postulated but highly unlikely accident scenario, typically set at $95 \%$. 
Figure 9 shows that the percentiles associated with an assumed bounding value of $k$ are greater than $99.999 \%$ confidence for all burnups. The increased probability corresponds to the lower uncertainty for actinides relative to fission products.

Assuming a $95 \%$ probability is acceptable, and comparing the difference between $\mathrm{k}_{\max }$ and $\mathrm{k}_{95 \%}$, it is found that the bounding approach consistently exceeds the $95 \%$ probability by roughly $2 \% \Delta k$ for all burnups in both plots. This is a measure of the excess conservatism associated with the bounding approach, but only applies to this cask design, this fuel enrichment, and this modeling approach. Nevertheless, these results indicate a potentially significant reduction in excess conservatism using a statistically derived approach. 


\section{CONCLUSIONS}

A method has been developed to incorporate biases and uncertainties in isotopic predictions into an uncertainty term for neutron multiplication. Uncertainties derived in this manner can be applied in a more realistic yet conservative fashion, without paying the penalties associated with the bounding approach currently recommended in proposed methodologies for transportation and storage.

The results contained herein reflect only three burnup states and a single cask or pin design. This report has been developed to show the utility of the KRONOS approach for the statistical study of the effect of isotopic prediction uncertainties, and to demonstrate the potential magnitude of the effect of those uncertainties on the predicted neutron multiplication factor for a given design. In these results, trends were observed as a function of: fission product vs. actinideonly isotopic models, increasing burnup, and pin-cell vs. cask models. At a $95 \%$ percentile, the statistical approach was found to reduce the conservatism associated with a bounding isotopic approach by approximately $2 \% \Delta k$, irrespective of burnup or the presence of fission products, for the cask models studied. Although heuristically it is expected that general trends noted here would be confirmed in additional analyses, such additional studies have not been performed and there is no technical justification for this. This is especially true in the magnitude of the $\Delta k$ margin observed. This margin may be dependent on the configuration of the cask, the codes and data used, and certainly will vary as additional assay data becomes available.

The non-normal distributions of $k$ observed with fission product data included result from large uncertainties in fission product measurements and calculations. Modified fission product concentrations of less than zero were set to zero. Since this results in an under population of the upper end of the distribution of $k$ values, the estimated mean value of $k$ and the deviation in $k$ are both slightly underestimated for higher burnups (although the effect is small). This problem could be rectified in two ways. First, it is possible to transform the uncertainties into a lognormal distribution and ensure that all uncertainties are positive, hence no truncation is necessary. A better approach would be to obtain additional fission product data, such that the associated uncertainties would be reduced, and a more realistic estimate of measurement uncertainties could be obtained.

The analyses described herein were detailed and computationally expensive, requiring the use of distributed network computing in order to complete analyses in a reasonable time. However, this relatively simple use of parallel processing was found to be extremely efficient and effective. 


\section{REFERENCES}

1. M. Rahimi, E. Fuentes, and D. Lancaster, Isotopic and Criticality Validation for PWR Actinide-Only Burnup Credit, DOE/RW-0497, Office of Civilian Radioactive Waste Management, U.S. Department of Energy, 1997.

2. U.S. Department of Energy, Topical Report on Actinide-Only Burnup Credit for PWR Spent Nuclear Fuel Packages, DOE/RW-0472 Rev 2, Office of Civilian Radioactive Waste Management, U.S. Department of Energy, 1998.

3. O. W. Hermann, S. M. Bowman, M. C. Brady, and C. V. Parks, Validation of the SCALE System for PWR Spent Fuel Isotopic Composition Analyses, ORNL/TM-12667, Martin Marietta Energy Systems, Inc., Oak Ridge Natl. Lab., March 1995.

4. M. D. DeHart and O. W. Hermann, An Extension of the Validation of SCALE (SAS2H) Isotopic Prediction for PWR Spent Fuel, ORNL/TM-13317, Lockheed Martin Energy Research Corp., Oak Ridge Natl. Lab., September 1996.

5. M. D. DeHart, Sensitivity and Parametric Evaluations of Significant Aspects of Burnup Credit for PWR Spent Fuel Packages, ORNL/TM-12973, Lockheed Martin Energy Research Corp., Oak Ridge Natl. Lab., May 1996.

6. O. W. Hermann and C. V. Parks, "SAS2H: A Coupled One-Dimensional Depletion and Shielding Analysis Module," Vol. I, Sect. S2 of SCALE: A Modular Code System for Performing Standardized Computer Analyses for Licensing Evaluation, NUREG/CR0200, Rev. 6 (ORNL/NUREG/CSD-2/R6), Vols. I, II, and III, May 2000. Available from Radiation Safety Information Computational Center at Oak Ridge National Laboratory as CCC-545.

7. M. D. DeHart and S. M. Bowman, Validation of the SCALE Broad Structure 44-Group ENDF/B-V Cross-Section Library for Use in Criticality Safety Analyses, NUREG/CR6102 (ORNL/TM-12460), U.S. Nuclear Regulatory Commission, Oak Ridge Natl. Lab., September 1994.

8. N. F. Landers and L. M. Petrie, "CSAS: Control Module for Enhanced Criticality Safety Analysis Sequences," Vol. I, Sect. C4 of SCALE: A Modular Code System for Performing Standardized Computer Analyses for Licensing Evaluation, NUREG/CR0200, Rev. 6 (ORNL/NUREG/CSD-2/R6), Vols. I, II, and III, May 2000. Available from Radiation Safety Information Computational Center at Oak Ridge National Laboratory as CCC-545.

9. W. Gropp, E. Lusk, and A. Skjellum, Using MPI - Portable Parallel Programming with the Message Passing Interface, The MIT Press, Cambridge, Massachusetts, 1996. 
10. J. C. Wagner, Computational Benchmark for Estimation of Reactivity Margin from Fission Products and Minor Actinides in PWR Burnup Credit, NUREG/CR-XXXX, ORNL/TM-2000/306, U.S. Nuclear Regulatory Commission, Oak Ridge Natl. Lab., in preparation. 


\section{APPENDIX A}




\section{KRONOS Fortran-90 Program Listing}

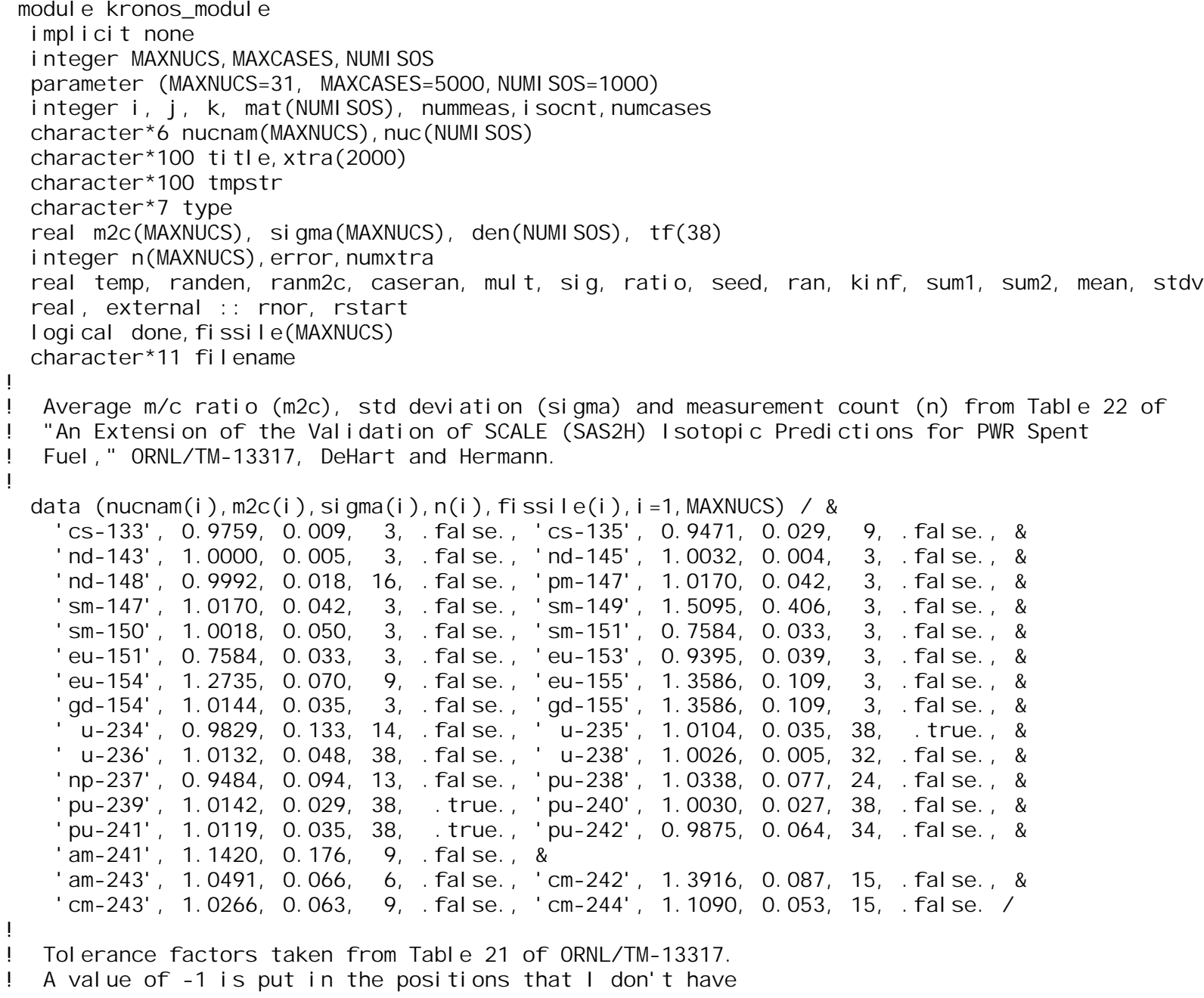




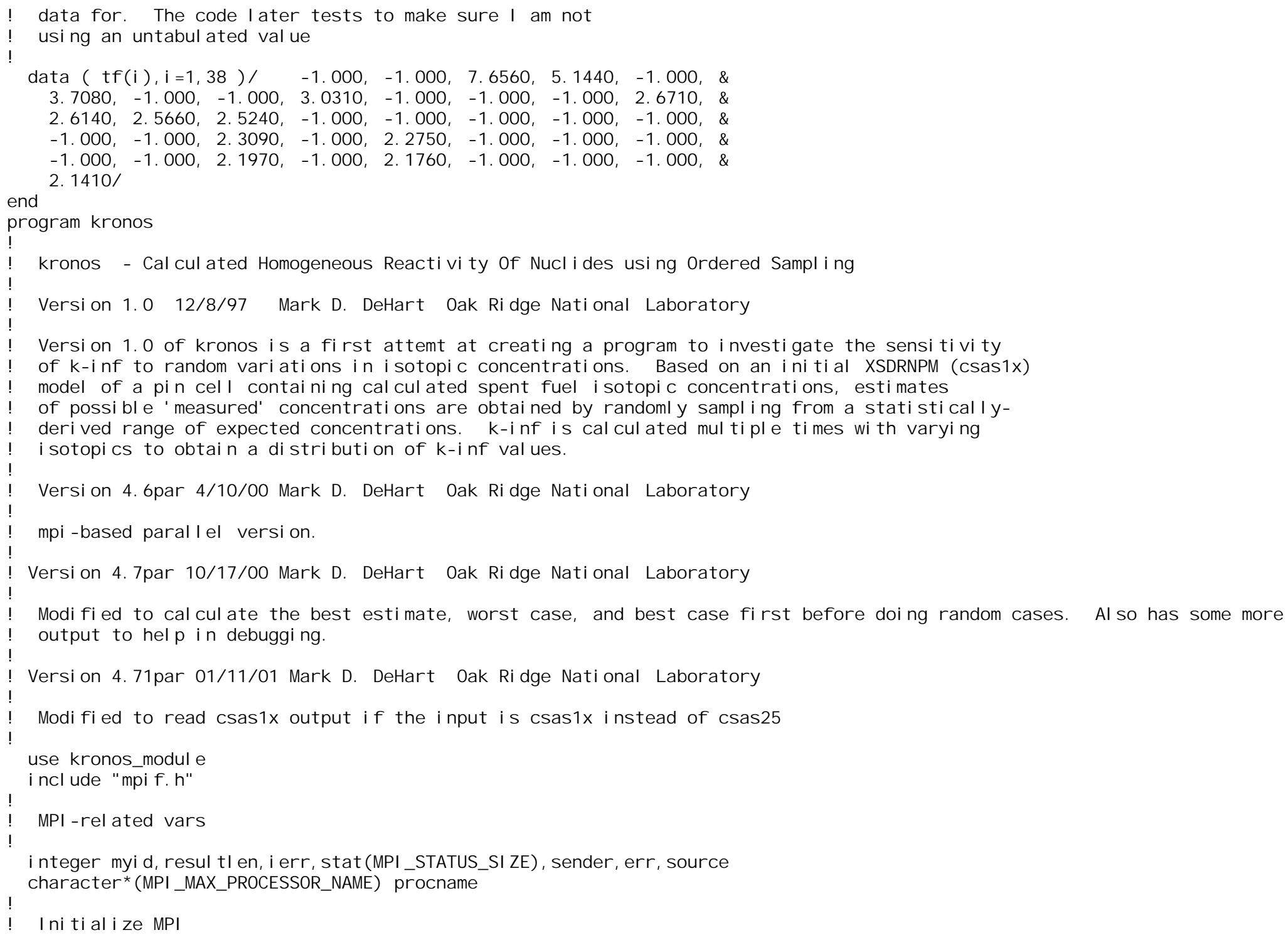




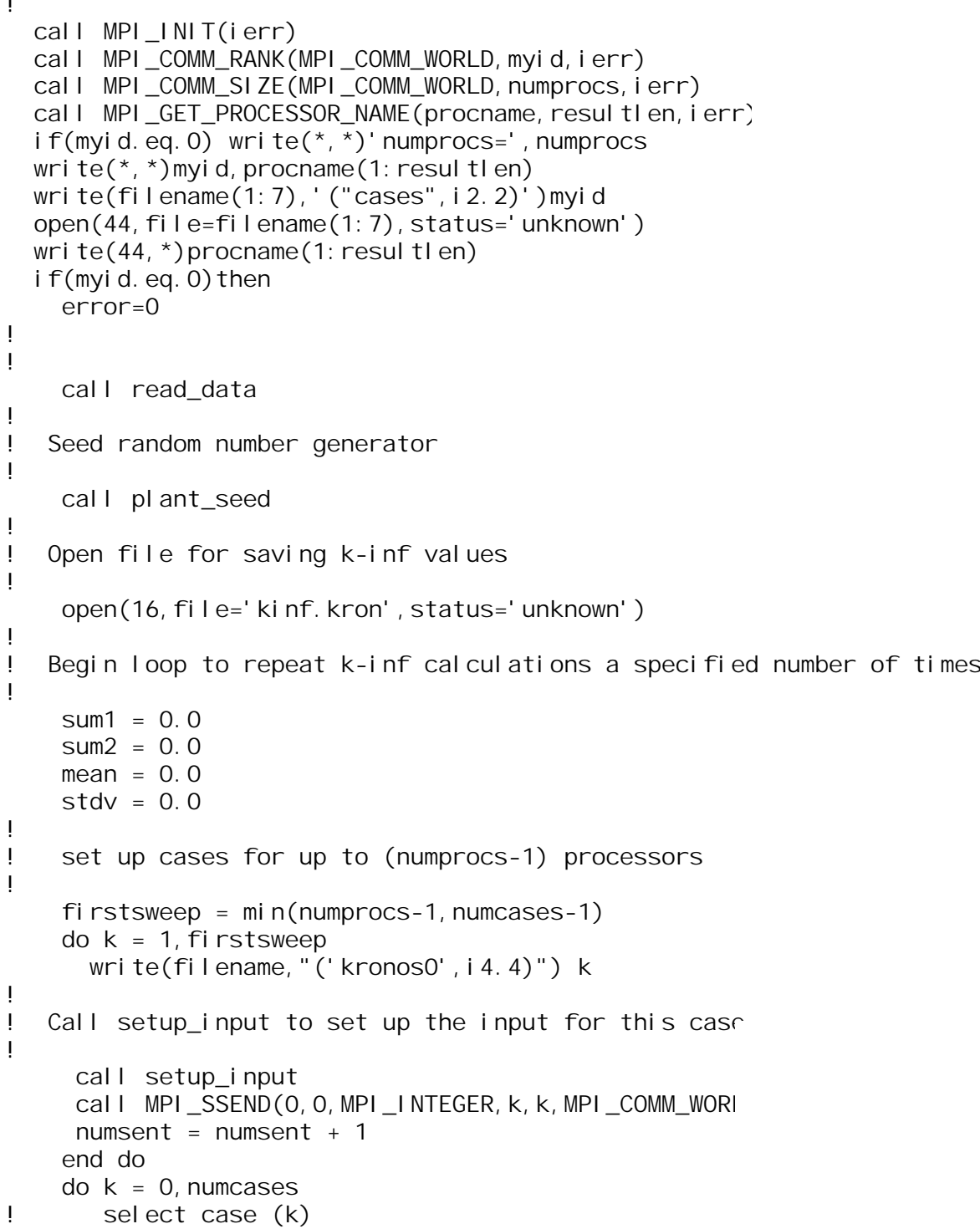

open( $16, \mathrm{fi}_{\mathrm{l}} \mathrm{e}=\mathrm{ki} \mathrm{nf} . \mathrm{kron}$, st at us $\rightleftharpoons$ unknown' )

Begi $n$ loop to repeat $k-i n f$ calcul at $i$ ons a specified number of ti res

sumi $=0.0$

sum2 $=0.0$

mean $=0.0$

stdv $=0$. o

set up cases for up to (numprocs-1) processors

first sweep $=$ mi n( numprocs- 1 , numeases- 1 )

do $k=1, f$ irst sweep

urite(fil enarre, "('kronoso', i 4.4)") k

Cal I set up_i nput to set up the i nput for thi s casi

cal I set up_i nput

cal I MPI_SSEND( O, O, MPI_I NTEGER, K, K, MPI_COMM_ VORI

numsent $=$ numsent +1

end do

do $k=0$, numeases

l sel ect case (k) 
case ( $0: 3)$

source $=\mathrm{k}+1$

case defaul $t$

source = MPI_ANY_SOURCE

end sel ect

cal I MPI_RECV(O, O, MPI I NTEGER, source, MPI_ANY_TAG

ZLD, st at, i er $r$ )

sender = stat ( $\mathrm{MPI}$ _SOURCE)

$\mathrm{kK}=\mathrm{stat}(\mathrm{MPI}$ - TAG)

urite( 44,*)' Recei ved from', sender, $k \mathrm{k}$

if (type( 6: 6). eq. ' 2 ') then

cal I read_out put $25(\mathrm{kk}$, sender)

el sei $f(t y p e(6: 6)$. eq. ' 1 ' ) then

cal I read_out put $1 \times(\mathrm{kk}$, sender $)$

endi $f$

if (numsent. I e. numcases)then ! there are more cases to run

numsent $=$ numsent +1

urite(fil ename, "('kronoso', i 4.4)") nunsent

cal I setup i nput

cal I MPI_SSEND( O, O, MPI_I NTEGER, sender, numsent, MPI_COMM_ WORLD, i er $r$ )

urite( $44, *)$ ' Sent to ', sender, numsent

el seif(error.eq. 1) then ! error conditi on set in read_out put

cal I MPI ABORT( MPI COMM MORLD, er ror)

cal I MPI FI NALI ZE(i er $r$ )

cl ose (44)

st op

el se ! we are done

cal I MPI _SSEND( O, O, MPI I NTEGER, sender, O, MPI COMM WORLD, i er $r$ )

urite( $44, *)$ ' Sent to', sender,' st op flag $(0)$ '

endi $f$

end do

el se ! this is a slave processor

done $=$. fal se.

do whil e (. not. done)

cal I MPI_RECV( $i, j$, MPI I NTEGER, O, MPI ANY TAG, MPI COMM WORLD, st at, i er $r$ )

$k=s t a t(M P I / T A G)$

urite( $44, *)$ ' Recei ved $k=', k$

$f(k$.eq. $O)$ then

done $=$. true.

el se

urite( $\mathrm{fi}$ l ename, "( ' $\left.\mathrm{kronos} \mathrm{O}^{\prime}, \mathrm{i} 4.4\right)$ ") $\mathrm{k}$

urite( $6, *)$ ' $F$ il enare, fil enare, ' on node', procname( 1 : resul tI en)

write $(44, *)$ fil enare

open( $19, \mathrm{fi}$ I $e \rightleftharpoons$ ni cel evel ', st at us $\rightleftharpoons$ ol d' )

read( 19, *) ni ce

cl ose( 19) 
pen( $19, \mathrm{fi}$ I e $=\mathrm{i}$ i l enarre, st at us $=$ unknown' )

write(19, "( "\#! / bi n/csh')")

urit e( 19, "( '\#', a) ") procname( 1: resul tI en)

uri te( 19, "(' set env SCALE / scal e4. 4')")

uri te( 19, " (' set env TMPDI R / var/t mo/ udq. ', i 5. 5) ") k

urite( 19, " (' ni ce +', i 2. 2,' \$SCALE/ crrds/ scal e4

', all, ' out' ) ") ni ce, $f \mathrm{i}$ l ename, fi l ename

urite(19, "( 'rm - rf \$TMPDI R' ) ")

urite(19," ('sleep 5')")

cl ose( 19)

cal I system ' chnod 755 '//fi I ename)

cal I system fil ename)

cal I system' $r \mathrm{~m}$ '//fil ename)

cal I MPI_SSEND( O, O, MPI _I NTEGER, O, K, MPI_COMM_ WORLD, i er r ) endi $f$

end do

endi $f$

cal I MPI FI NALI ZE( i er $r$ )

cl ose (44)

st op

end

real function $r$ nor ()

***purpose generates normal random numbers, with mean zero and

! uni $t$ standard deviation, of ten denot ed $n(0,1)$.

***description

$r$ nor gener at es nor mal $r$ andom numbers with zero mean and

uni $t$ standard deviation, of ten denoted $n(0,1)$.

fromthe book, "numerical methods and software" by

d. kahaner, C. nol er, s. nash

prenti ce hal I, 1988

first ti me...

$$
z=\text { rstart (i seed) }
$$

here i seed is any $n o n-z$ e $r o$ integer.

this causes initialization of the program

rstart returns a real (single precision) echo of i seed.

subsequent ti mes. .

$z=r$ nor ()

causes the next real (single precision) random number

$$
\text { to be returned as } z \text {. }
$$

typi cal usage 


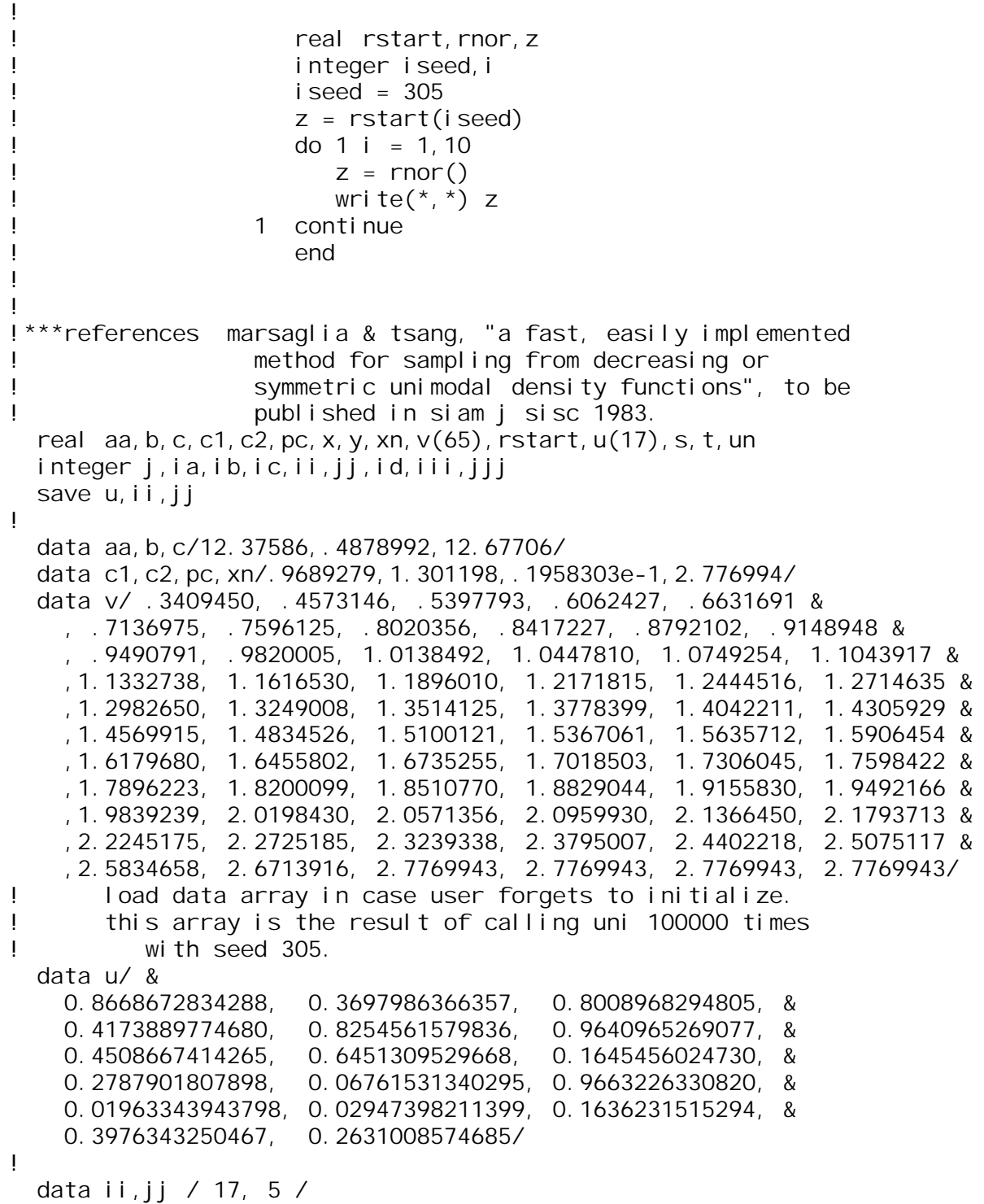




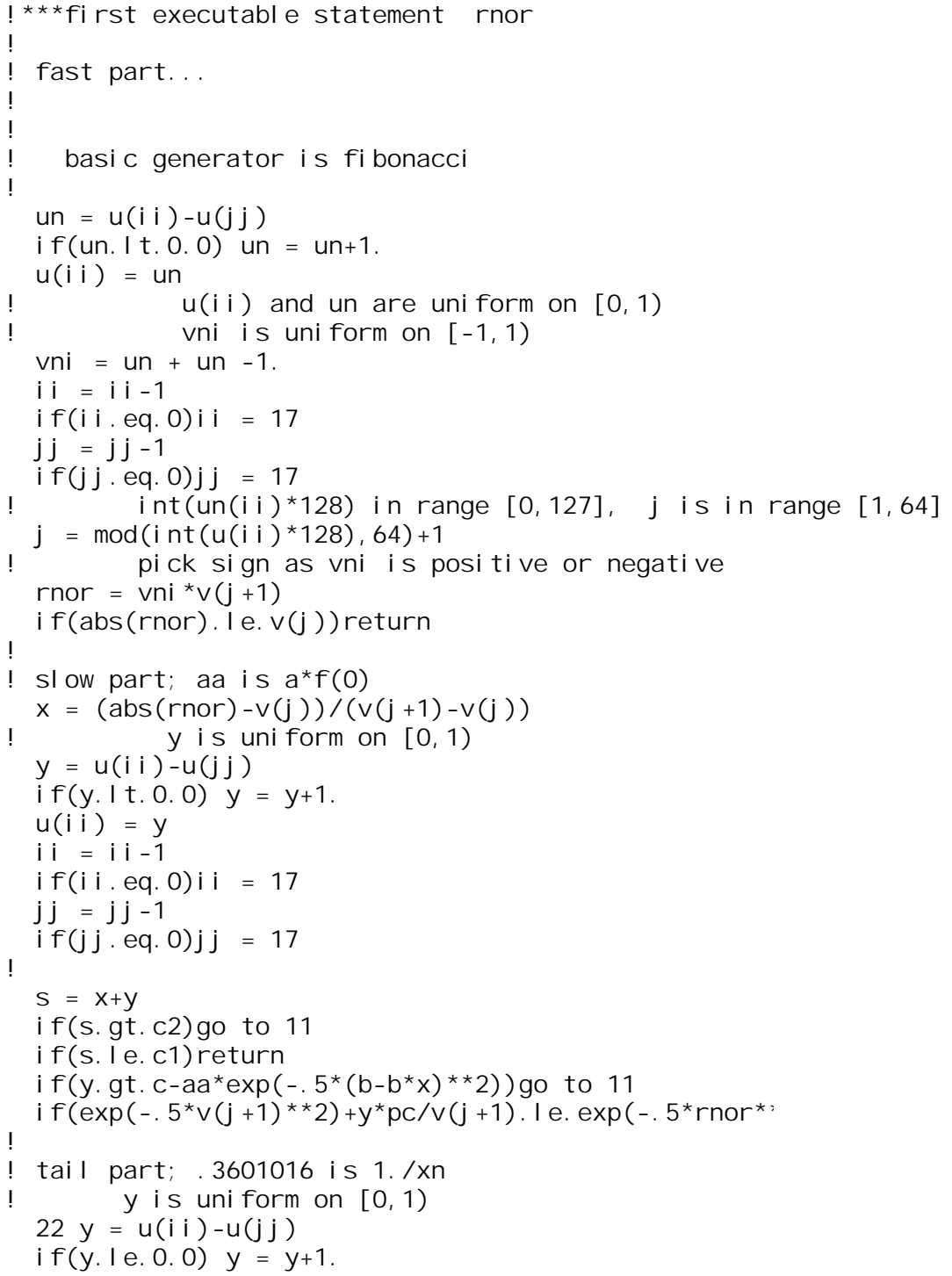




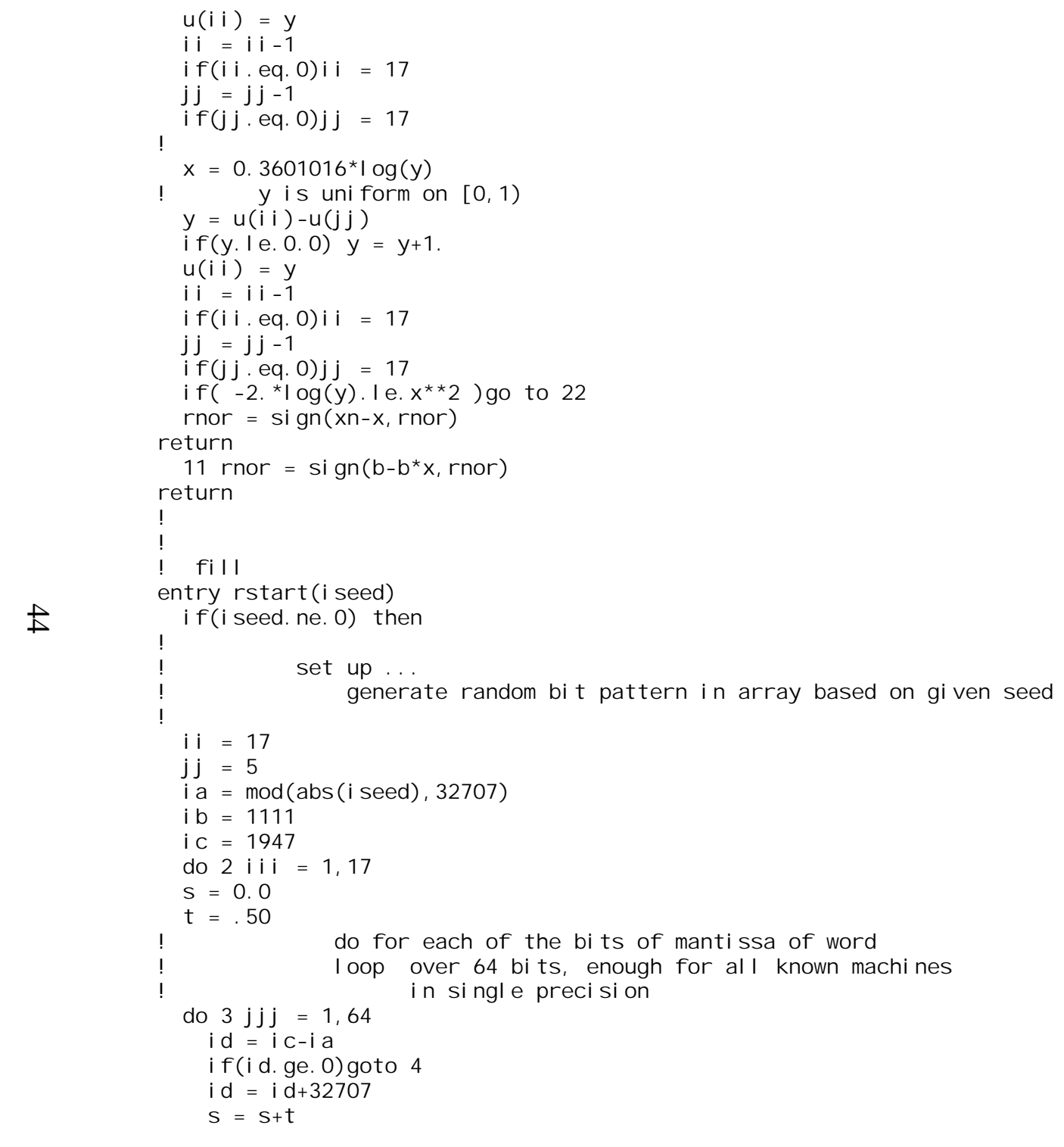


$4 \quad i a=i b$

$i b=i c$

$\mathrm{i} c=\mathrm{id}$

$3 \mathrm{t}=.5 * \mathrm{t}$

$2 u(i i i)=s$

endi $f$

return

subrout i ne read_data

use $\mathrm{kr}$ onos_rrodul e

character*80 inst

open i nput file and read i nitial (calcul ated) isotopics and problem description froma csaslx file.

open( $16, \mathrm{fi}_{\mathrm{i}} \mathrm{e}=$ numeases', st at us $\rightleftharpoons$ ol $\left.\mathrm{d}^{\prime}\right)$

read $(16, *)$ numeases

cl ose (16)

Write( 6, ' ( $\mathrm{i} 4$, , hi stories will be $r$ un. ")' ) numeases

open( $16, \mathrm{fi} I \mathrm{e} \rightleftharpoons \mathrm{kronos}$. dat', st at us $\rightleftharpoons$ ol d' )

read(16,' (a7)' ) type

Read fuel nucli des

!!! do $\mathrm{i}=1$, NUM SOS

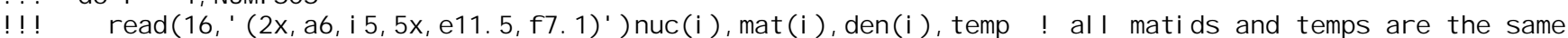
!!! end do

i socnt $=0$

done $=$. fal se.

do whi le (. not. done)

read( 16, ' ( a80)' ) i nstr

if (instr( 1: 1). eq. " " ") cycle

if (instr ( 1: 3) . eq. "END") then

done $=$. true.

el se

$\mathrm{i}$ socnt $=\mathrm{i}$ socnt +1

read( i nst $r, \cdot(2 x, a 6)$ ') nuc ( $i$ socnt )

read( inst $r(9: 80), *)$ mat ( $i$ socnt), i dum den( $i$ socnt)

$$
\text { endi } f
$$

Read remai ni ng i nput 
numxtra $=$ numxt ra +1

end do

$99 \mathrm{cl}$ ose (16)

return

end

subrouti ne pl ant_seed

use kronos_nodul e

seed $=1234567890$

cal I random number ( HARVEST=seed)

ran $=$ rstart (seed)

return

end

subrouti ne set up_i nput

use kronos_modul e

Open an i nput file and urite header i nf or mat i on

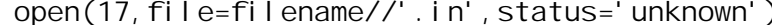

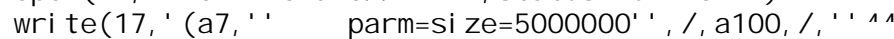

sel ect case ( $f$ il enare)

case (' kronosoooo1')

uri te( 17, " (' ' Nomi nal (unbi ased) case' ) ")

case (' kronos00002')

uri te (17," (' 'Bi ased case')" )

case (' kronosoooo3')

write( 17, "( ' ' Maxi mum case' ) ")

case (' kronosoooo4')

urite( 17, "( ' 'M ni mum case' ) ")

case defaul $t$

uri te( 17, "( ' ' Random case' ) ")

end sel ect

For each nuclide in the input listing, scan thru the list of tabul ated nuclides, to see

if there is a match. Compute a randomized $n x c$ ratio, using 1. 0 H-0. 999999 for unmeasured

nucl i des. Modify the i nput val ue for the i sotopic concentration, and urite std comp data.

do $\mathrm{i}=1$, i socnt

ratio $=1$. 000

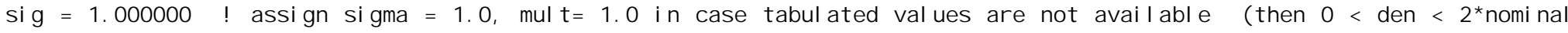

den)

mell $t=1.000$ 


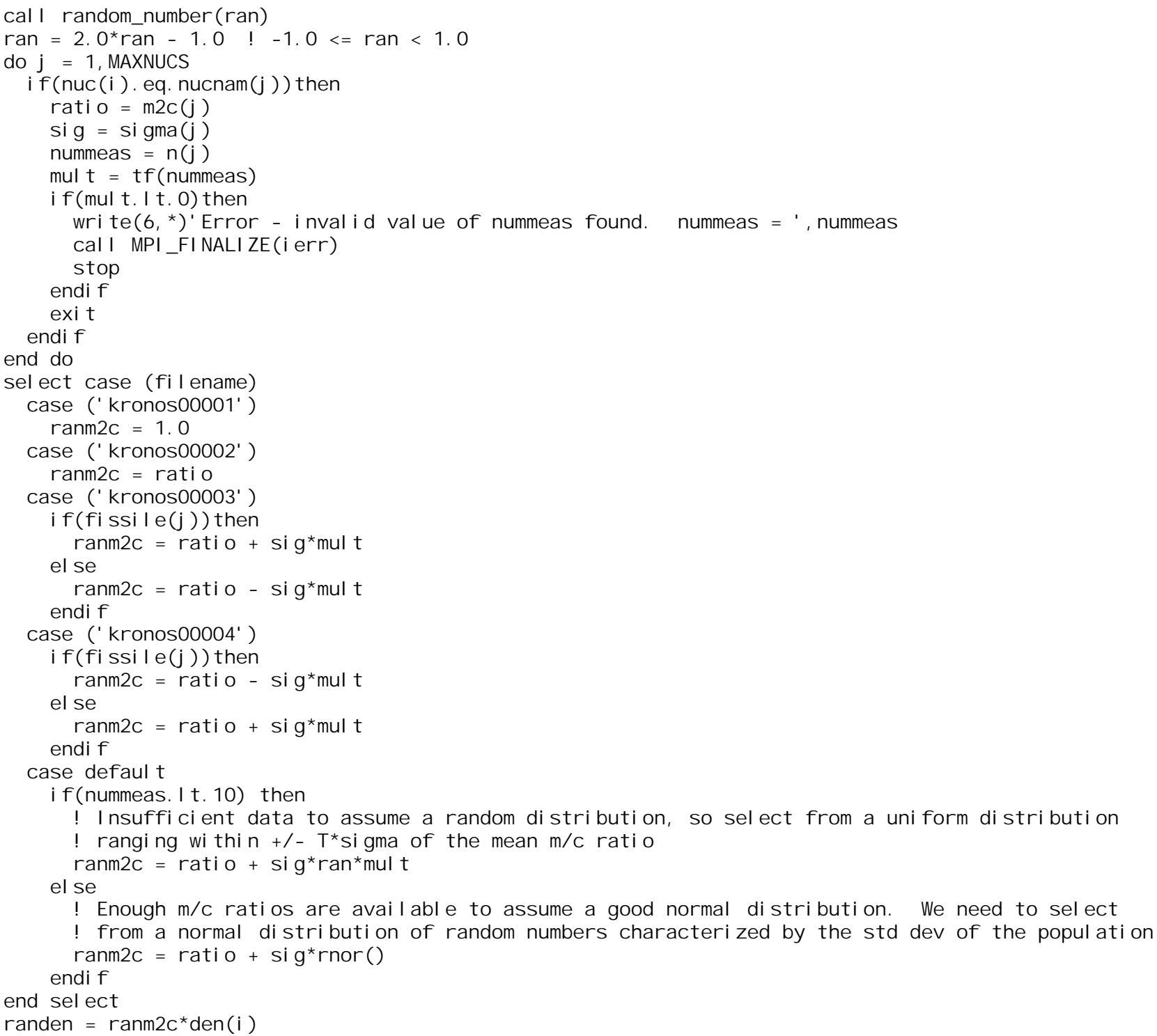


i f ( randen. I e. 1. Oe- 20) randen $=1$. Oe- 20

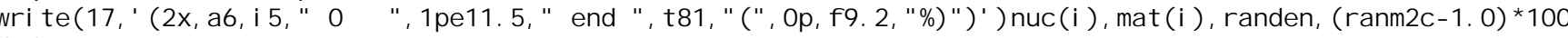
end do

! write remai ni ng i nput

do $\mathrm{i}=1$, numstra

urite(17, ' (a100)') xtra(i)

end do

cl ose( 17)

return

end

subrout i ne read_out put 25( $\mathrm{i}$ casenum sender)

use kronos_rodul e

i nt eger casenum sender

real twosig

l ogical l exi st

urite( fil enarre, "( ' kronoso', i 4. 4)") i casenum

open $(17, \mathrm{fi}$ l e $=f \mathrm{i}$ I ename//' . i n', st at us $=$ ol d'

i nqui re(fil $e=$ debug', exi st $\Rightarrow$ exi st)

if ( $I$ exist $)$ then

cl ose (17)

cal I system (' compress '//fil I enare//'. i n')

el se

cl ose (17, st at us $=$ del et $\left.e^{\prime}\right)$

endi $f$

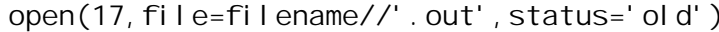

do

$\operatorname{read}(17, \cdot(23 x$, a50)' , end=999) t mpst $r(1: 50)$

if ( $\operatorname{tmostr}(1: 50)$. eq. ' $p l$ ot of average $k$-effective by generation ski pped. ') then read( 17, " ( 34x, f 6. 4, 9x, f 6. 4) ") ki nf, t wosi g

$k k=k-3$ ! First four ( $0-3)$ val ues are not $i$ ncl uded in the mean

i f ( k. gt. 3) then

suml $=$ sumi $+k i n f * k i n f$

sume $=$ sume $+k i n f$

mean $=$ sumz/ $\mathrm{kK}$

endi $f$

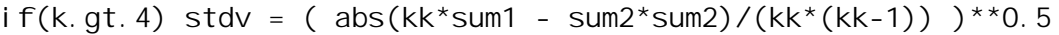

i $f(k$. eq. 0$)$ then

urite(16,"('k-eff sigma mean $k$ mean $s$ case mach.')")

urite(6," ('k-eff sigma mean $k$ mean $s$ case mach. ")")

endi $f$

sel ect case ( $i$ casenum)

case (1) 
wri te $(16,124) \mathrm{ki} n f, \mathrm{t}$ wosi g, ' nomin nal', i casenum sender wri te $(6,124) \mathrm{ki} \mathrm{hf}, \mathrm{t}$ wosi g, ' nomi nal ', i casenum sender case (2)

uri te $(16,124) \mathrm{ki} n f$, thosi g, ' best est', i casenum sender

uri te $(6,124) \mathrm{ki} n f, \mathrm{t}$ wosi g, ' best est', i casenum sender case ( 3 )

wri te (16, 124) ki nf, t wosi g, ' maxi mum, i casenum sender

writ e $(6,124) \mathrm{ki} \mathrm{hf}, \mathrm{t}$ wosi g, ' maxi mum, i casenum sender case (4)

uri te 16,124$) \mathrm{ki} n f$, t wosi g, ' mi ni mum, i casenum sender

wri te $(6,124) \mathrm{ki} \mathrm{hf}, \mathrm{t}$ wosi $\mathrm{g}$.' 'mi ni mum, i casenum sender case (5:)

wri te $(16,123) \mathrm{ki} n f, t$ wosi g, mean, st dv, i casenum sender

wri te $(6,123) \mathrm{ki} \mathrm{nf}, \mathrm{t}$ wosi g, mean, st dv, i casenum se end sel ect

123 for mat ( $4(f 6,4,2 x), 2(i 5))$

124 for mat ( $2(f 6,4,2 x), 3 x, a 7,6 x, 2(i 5))$

exit

endi $f$

end do

if ( 1 exist $)$ then

cl ose( 17)

cal I system ('compress '//fil ename//'. out') el se

cl ose (17, st at us $=$ del et $e^{\prime}$

endi $f$

return

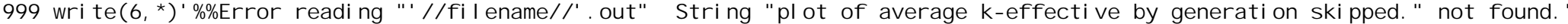
$\mathrm{cl}$ ose (17, st at us $=$ keep' )

error $=1$

return

end

subr out i ne read_out put $1 \times(\mathrm{i}$ casenum sender)

use kronos_modul e

int eger casenum sender

logical l exist

uri te( fil enarre, "('kronoso', i 4.4)") i casenum

open( $17, \mathrm{fi} I \mathrm{e}=\mathrm{f} \mathrm{i}$ I enarre// ' . i $\mathrm{n}$ ', st at us $=$ ol d' )

i nqui $r e(f i l e=$ debug', exi st $\Rightarrow$ exi st)

if ( I exist) then

cl ose (17)

cal I system ('compress '//fil I enare//'. i n')

el se

$\mathrm{cl}$ ose (17, st at us $=$ del et e' $)$

$$
\text { endi } f
$$


open( $17, \mathrm{fi}^{\mathrm{i}} \mathrm{l}$ e $=\mathrm{f} \mathrm{i}$ I enarre/ / ' . out', st at us $=$ ol $\mathrm{d}^{\prime}$ )

do

read( 17, ' (13x, a13)', end=999) t most $r(1: 13)$

if ( t mpst $r(1: 13)$. eq. ' fi nal monitor') then

read(17, "( 28x, e11. 5) ") ki nf

$k k=k-3$ ! First four ( $0-3)$ val ues are not incl uded in the mean

i $f(k . g t .3)$ then

sumi $=$ suml $+k i n f * k i n f$

sump $=$ sump $+\mathrm{kinf}$

mean $=$ sump/ $\mathrm{kK}$

endi $f$

i $f(k . g t .4)$ stdv $=\left(\operatorname{abs}\left(k k^{*}\right.\right.$ suml - sum2*sump $\left.) /\left(k k^{*}(k k-1)\right)\right) * * 0.5$

$f(k$. eq. 0$)$ then

urite(16," ('k-eff mean $k$ mean $s$ case mach.')")

uritel 6 , "('k-eff mean $k$ mean $s$ case mach.

sel ect case (i casenum

case (1)

wri te $(16,124) \mathrm{ki} \mathrm{nf}$, ' nomi nal', i casenum sender

uri te $(6,124) \mathrm{ki} \mathrm{nf}$, ' nomi nal', i casenum sender case (2)

wri te $(16,124) \mathrm{ki} \mathrm{nf,} \mathrm{'} \mathrm{best} \mathrm{est',} \mathrm{i} \mathrm{casenum} \mathrm{sender}$

uri te $(6,124) \mathrm{ki} n f$, ' best est', i casenum sender case (3)

wri te $(16,124) \mathrm{ki} \mathrm{hf,} \mathrm{'} \mathrm{maxi} \mathrm{mum,} \mathrm{i} \mathrm{casenum} \mathrm{sender}$ write( 6,124$) \mathrm{ki} \mathrm{nf}$, ' maxi mum, i casenum sender case (4)

wri te $(16,124) \mathrm{ki} \mathrm{hf,} \mathrm{'} \mathrm{mi} \mathrm{ni} \mathrm{mum,} \mathrm{i} \mathrm{casenum} \mathrm{sender}$

wri te $(6,124) \mathrm{ki} \mathrm{nf}$, ' mi ni mum, i casenum sender case (5:)

wri te $(16,123) \mathrm{ki} \mathrm{hf}$, mean, st dv, i casenum sender uri te $(6,123) \mathrm{ki} n$, mean, st dv, i casenum sender end sel ect

123 f or mat ( $3(f 6,4,2 x), 2(i, 5))$

124 format ( f 6. 4, 2x, 3x, a7, 6x, 2(i 5) )

exi $t$

endi $f$

end do

if ( 1 exist) then

cl ose (17)

cal I system ('compress '//fi I enare//'. out')

el se

cl ose( 17 , st at us $=$ del et $\left.e^{\prime}\right)$

endi $f$

return 
999 write(6, *) " \%Error reading " //fil ename//". out" String "final monitor" not found."

cl ose (17, st at us $=$ keep' )

error $=1$

return

end

subrout i ne read_out put 2 ( $i$ casenum er $r$ )

use $\mathrm{kr}$ onos_rodul e

i nt eger casenumer $r$

er $r=0$

urite( fill ename, "(' $k r$ onoso' , i 4. 4) ") i casenum

open( $17, \mathrm{f} i \mathrm{l}$ e $=\mathrm{f} \mathrm{i}$ I ename//'. out', st at us $=$ ol d' )

do

read( $17,{ }^{\prime}(23 x, a 50)$ ' , end=999) t mpst $r(1: 50)$

if ( $t$ mpstr( 1:50). eq. ' pl ot of average k-effective by generation ski pped.' ) exit end do

cl ose (17)

return

999 write( 6,*) 'Error reading ".//fill ename//'. out" SI

cl ose (17)

er $r=1$

return

If average k-effective by generation ski pped." not found." 


\section{APPENDIX B}

\section{SAMPLE BASELINE INPUT MODELS USED BY KRONOS}




\section{APPENDIX B \\ SAMPLE BASELINE INPUT MODELS USED BY KRONOS}

\section{Sample 1: KRONOS KENO Cask model, non-uniform axial profile, actinides only, 20 GWd/MTU}

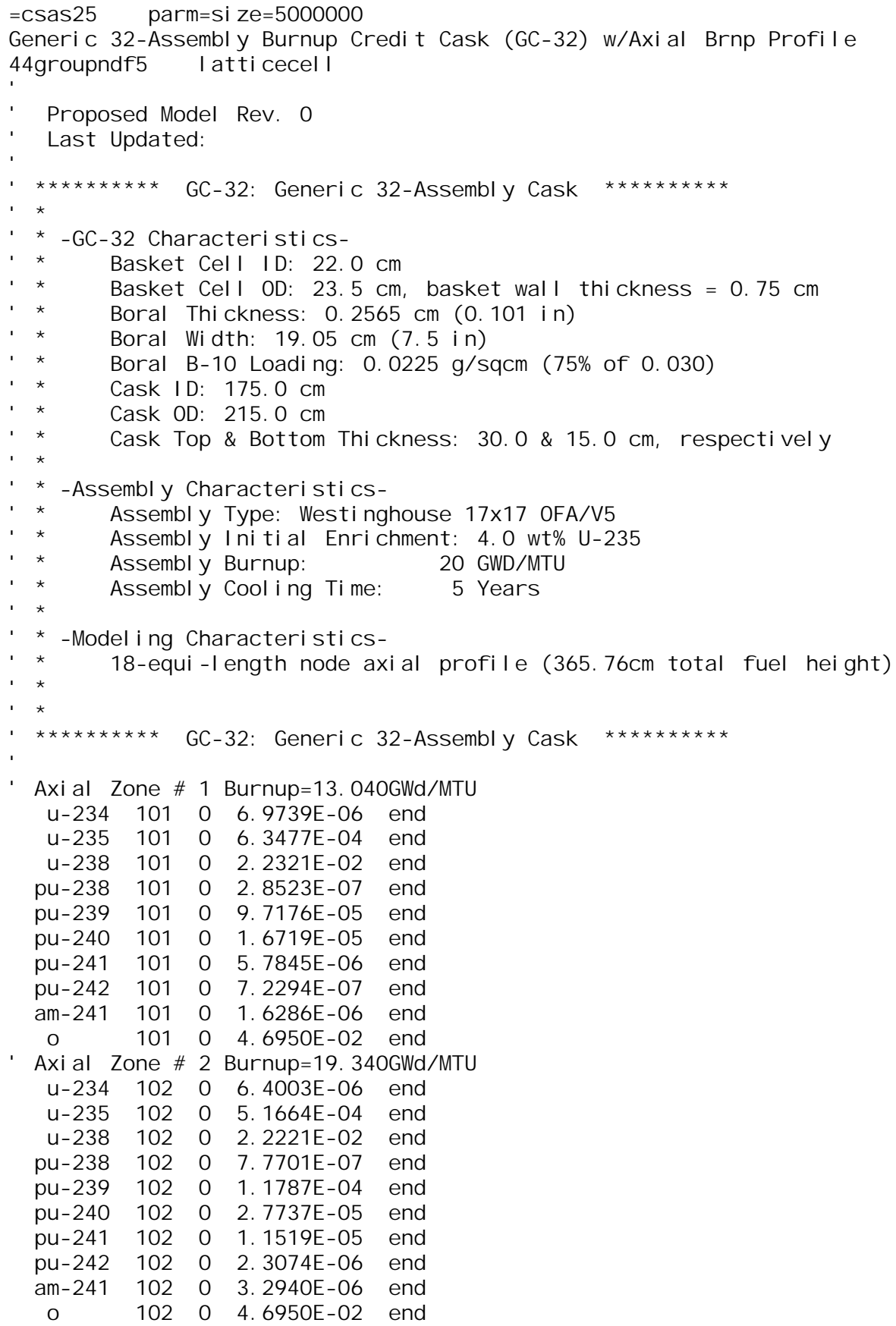




\begin{tabular}{|c|c|c|c|c|}
\hline Axial & Zone & & Burnup = & GWd I $M$ \\
\hline$u-234$ & 103 & 0 & $6.2146 \mathrm{E}-06$ & end \\
\hline$u-235$ & 103 & 0 & $4.8053 \mathrm{E}-04$ & end \\
\hline$u-238$ & 103 & 0 & 2. $2186 \mathrm{E}-02$ & end \\
\hline pu- 238 & 103 & 0 & 1. $0134 \mathrm{E}-06$ & end \\
\hline pu- 239 & 103 & 0 & 1. $2283 \mathrm{E}-04$ & end \\
\hline pu- 240 & 103 & 0 & 3. $1408 E-05$ & end \\
\hline pu- 241 & 103 & 0 & 1. $3522 \mathrm{E}-05$ & end \\
\hline pu- 242 & 103 & 0 & $3.0803 \mathrm{E}-06$ & end \\
\hline a m- 241 & 103 & 0 & $3.8853 \mathrm{E}-06$ & end \\
\hline 0 & 103 & 0 & $4.6950 \mathrm{E}-02$ & end \\
\hline Axial & Zone \# & 4 & Burnup $=22.06$ & OGWd / MTU \\
\hline$u-234$ & 104 & 0 & $6.1651 \mathrm{E}-06$ & end \\
\hline$u-235$ & 104 & 0 & $4.7107 \mathrm{E}-04$ & end \\
\hline$u-238$ & 104 & 0 & 2. $2176 \mathrm{E}-02$ & end \\
\hline pu- 238 & 104 & 0 & $1.0839 \mathrm{E}-06$ & end \\
\hline pu- 239 & 104 & 0 & 1. $2403 \mathrm{E}-04$ & end \\
\hline$p u-240$ & 104 & 0 & $3.2391 \mathrm{E}-05$ & end \\
\hline pu- 241 & 104 & 0 & $1.4060 E-05$ & end \\
\hline$p u-242$ & 104 & 0 & $3.3101 \mathrm{E}-06$ & end \\
\hline a m- 241 & 104 & 0 & $4.0450 E-06$ & end \\
\hline 0 & 104 & 0 & $4.6950 \mathrm{E}-02$ & end \\
\hline Axial & Zone \# & 5 & Burnup $=22.16$ & O GWd / MTU \\
\hline$u-234$ & 105 & 0 & $6.1566 \mathrm{E}-06$ & end \\
\hline$u-235$ & 105 & 0 & $4.6945 E-04$ & end \\
\hline$u-238$ & 105 & 0 & 2. $2175 \mathrm{E}-02$ & end \\
\hline$p u-238$ & 105 & 0 & 1.0962E-06 & end \\
\hline pu- 239 & 105 & 0 & 1. $2422 \mathrm{E}-04$ & end \\
\hline$p u-240$ & 105 & 0 & $3.2560 \mathrm{E}-05$ & end \\
\hline$p u-241$ & 105 & 0 & 1. $4153 \mathrm{E}-05$ & end \\
\hline pu- 242 & 105 & 0 & $3.3506 \mathrm{E}-06$ & end \\
\hline a m- 241 & 105 & 0 & $4.0726 \mathrm{E}-06$ & end \\
\hline 0 & 105 & 0 & $4.6950 \mathrm{E}-02$ & end \\
\hline Axial & Zone \# & 6 & Burnup $=22.12$ & O GWd / MT \\
\hline$u-234$ & 106 & 0 & $6.1600 \mathrm{E}-06$ & end \\
\hline$u-235$ & 106 & 0 & $4.7010 E-04$ & end \\
\hline$u-238$ & 106 & 0 & $2.2175 \mathrm{E}-02$ & end \\
\hline pu- 238 & 106 & 0 & 1.0912E-06 & end \\
\hline pu- 239 & 106 & 0 & 1. $2415 \mathrm{E}-04$ & end \\
\hline$p u-240$ & 106 & 0 & 3. $2492 \mathrm{E}-05$ & end \\
\hline pu- 241 & 106 & 0 & $1.4116 \mathrm{E}-05$ & end \\
\hline$p u-242$ & 106 & 0 & $3.3344 \mathrm{E}-06$ & end \\
\hline a m- 241 & 106 & 0 & $4.0616 \mathrm{E}-06$ & end \\
\hline 0 & 106 & 0 & $4.6950 \mathrm{E}-02$ & end \\
\hline Axial & Zone \# & 7 & Burnup $=22.04$ & O GWd / MT U \\
\hline$u-234$ & 107 & 0 & $6.1668 \mathrm{E}-06$ & end \\
\hline$u-235$ & 107 & 0 & $4.7140 E-04$ & end \\
\hline$u-238$ & 107 & 0 & $2.2177 \mathrm{E}-02$ & end \\
\hline pu- 238 & 107 & 0 & $1.0814 \mathrm{E}-06$ & end \\
\hline$p u-239$ & 107 & 0 & 1. $2399 \mathrm{E}-04$ & end \\
\hline$p u-240$ & 107 & 0 & $3.2357 \mathrm{E}-05$ & end \\
\hline pu- 241 & 107 & 0 & $1.4041 \mathrm{E}-05$ & end \\
\hline pu- 242 & 107 & 0 & $3.3020 E-06$ & end \\
\hline a m- 241 & 107 & 0 & $4.0394 \mathrm{E}-06$ & end \\
\hline 0 & 107 & 0 & $4.6950 E-02$ & end \\
\hline Axial & Zone \# & 8 & Burnup $=21.94$ & O GWd / MT U \\
\hline$u-234$ & 108 & 0 & $6.1753 \mathrm{E}-06$ & end \\
\hline$u-235$ & 108 & 0 & $4.7302 \mathrm{E}-04$ & end \\
\hline$u-238$ & 108 & 0 & 2. $2178 \mathrm{E}-02$ & end \\
\hline pu- 238 & 108 & 0 & 1.0690E-06 & end \\
\hline pu- 239 & 108 & 0 & $1.2379 \mathrm{E}-04$ & end \\
\hline$p u-240$ & 108 & 0 & $3.2188 \mathrm{E}-05$ & end \\
\hline pu-241 & 108 & 0 & 1. $3949 \mathrm{E}-05$ & end \\
\hline pu- 242 & 108 & 0 & $3.2618 \mathrm{E}-06$ & end \\
\hline a m- 241 & 108 & 0 & $4.0121 \mathrm{E}-06$ & end \\
\hline 0 & 108 & 0 & $4.6950 E-02$ & end \\
\hline Axial & Zone \# & 9 & Burnup $=21.88$ & 0 GWd I \\
\hline$u-2$ & 109 & 0 & $6.1804 \mathrm{E}-06$ & end \\
\hline
\end{tabular}




\begin{tabular}{|c|c|c|c|c|}
\hline$u-235$ & 109 & 0 & $4.7399 E-04$ & end \\
\hline$u-238$ & 109 & 0 & $2.2179 \mathrm{E}-02$ & end \\
\hline$p u-238$ & 109 & 0 & $1.0617 \mathrm{E}-06$ & end \\
\hline$p u-239$ & 109 & 0 & 1. $2367 \mathrm{E}-04$ & end \\
\hline$p u-240$ & 109 & 0 & $3.2087 \mathrm{E}-05$ & end \\
\hline$p u-241$ & 109 & 0 & 1. $3894 \mathrm{E}-05$ & end \\
\hline$p u-242$ & 109 & 0 & $3.2378 E-06$ & end \\
\hline a m- 241 & 109 & 0 & $3.9956 E-06$ & end \\
\hline 0 & 109 & 0 & $4.6950 E-02$ & end \\
\hline Axial & Zone & \#10 & Burnup $=21.88$ & OGWd / MT U \\
\hline$u-234$ & 110 & 0 & $6.1804 \mathrm{E}-06$ & end \\
\hline$u-235$ & 110 & 0 & $4.7399 E-04$ & end \\
\hline$u-238$ & 110 & 0 & $2.2179 \mathrm{E}-02$ & end \\
\hline$p u-238$ & 110 & 0 & $1.0617 \mathrm{E}-06$ & end \\
\hline$p u-239$ & 110 & 0 & 1. $2367 \mathrm{E}-04$ & end \\
\hline$p u-240$ & 110 & 0 & $3.2087 \mathrm{E}-05$ & end \\
\hline$p u-241$ & 110 & 0 & 1. $3894 \mathrm{E}-05$ & end \\
\hline$p u-242$ & 110 & 0 & $3.2378 E-06$ & end \\
\hline a m- 241 & 110 & 0 & $3.9956 \mathrm{E}-06$ & end \\
\hline 0 & 110 & 0 & $4.6950 \mathrm{E}-02$ & end \\
\hline Axial & Zone & \#11 & Burnup $=21.90$ & O GWd / MT U \\
\hline$u-234$ & 111 & 0 & $6.1787 \mathrm{E}-06$ & end \\
\hline$u-235$ & 111 & 0 & $4.7367 \mathrm{E}-04$ & end \\
\hline$u-238$ & 111 & 0 & $2.2179 E-02$ & end \\
\hline$p u-238$ & 111 & 0 & 1. $0641 \mathrm{E}-06$ & end \\
\hline$p u-239$ & 111 & 0 & 1. $2371 \mathrm{E}-04$ & end \\
\hline$p u-240$ & 111 & 0 & $3.2121 E-05$ & end \\
\hline$p u-241$ & 111 & 0 & 1. $3912 \mathrm{E}-05$ & end \\
\hline$p u-242$ & 111 & 0 & $3.2458 \mathrm{E}-06$ & end \\
\hline a m- 241 & 111 & 0 & $4.0009 E-06$ & end \\
\hline 0 & 111 & 0 & $4.6950 E-02$ & end \\
\hline Axial & Zone & \#12 & Burnup $=21.92$ & O GWd / MTU \\
\hline$u-234$ & 112 & 0 & $6.1770 \mathrm{E}-06$ & end \\
\hline$u-235$ & 112 & 0 & $4.7334 \mathrm{E}-04$ & end \\
\hline$u-238$ & 112 & 0 & $2.2179 \mathrm{E}-02$ & end \\
\hline$p u-238$ & 112 & 0 & $1.0666 \mathrm{E}-06$ & end \\
\hline$p u-239$ & 112 & 0 & 1. $2375 \mathrm{E}-04$ & end \\
\hline$p u-240$ & 112 & 0 & $3.2155 \mathrm{E}-05$ & end \\
\hline$p u-241$ & 112 & 0 & 1. $3931 \mathrm{E}-05$ & end \\
\hline$p u-242$ & 112 & 0 & $3.2538 \mathrm{E}-06$ & end \\
\hline a m- 241 & 112 & 0 & $4.0065 \mathrm{E}-06$ & end \\
\hline 0 & 112 & 0 & $4.6950 E-02$ & end \\
\hline Axial & Zone & \#13 & Burnup $=21.90$ & O GWd / MT U \\
\hline$u-234$ & 113 & 0 & $6.1787 \mathrm{E}-06$ & end \\
\hline$u-235$ & 113 & 0 & $4.7367 \mathrm{E}-04$ & end \\
\hline$u-238$ & 113 & 0 & $2.2179 \mathrm{E}-02$ & end \\
\hline$p u-238$ & 113 & 0 & 1. $0641 \mathrm{E}-06$ & end \\
\hline$p u-239$ & 113 & 0 & 1. $2371 \mathrm{E}-04$ & end \\
\hline$p u-240$ & 113 & 0 & $3.2121 \mathrm{E}-05$ & end \\
\hline$p u-241$ & 113 & 0 & 1. $3912 E-05$ & end \\
\hline$p u-242$ & 113 & 0 & 3. $2458 \mathrm{E}-06$ & end \\
\hline a m- 241 & 113 & 0 & $4.0009 E-06$ & end \\
\hline 0 & 113 & 0 & $4.6950 E-02$ & end \\
\hline Axial & Zone & \#14 & Burnup $=21.72$ & O GWd / MT U \\
\hline$u-234$ & 114 & 0 & $6.1940 \mathrm{E}-06$ & end \\
\hline$u-235$ & 114 & 0 & $4.7660 \mathrm{E}-04$ & end \\
\hline$u-238$ & 114 & 0 & $2.2182 \mathrm{E}-02$ & end \\
\hline$p u-238$ & 114 & 0 & 1. $0422 \mathrm{E}-06$ & end \\
\hline$p u-239$ & 114 & 0 & 1. $2333 \mathrm{E}-04$ & end \\
\hline$p u-240$ & 114 & 0 & $3.1816 \mathrm{E}-05$ & end \\
\hline$p u-241$ & 114 & 0 & 1. $3745 \mathrm{E}-05$ & end \\
\hline$p u-242$ & 114 & 0 & $3.1743 \mathrm{E}-06$ & end \\
\hline a m- 241 & 114 & 0 & $3.9515 \mathrm{E}-06$ & end \\
\hline 0 & 114 & 0 & $4.6950 E-02$ & end \\
\hline Axial & Zone & \#15 & Burnup $=21.18$ & O GWd / MTU \\
\hline$u-234$ & 115 & 0 & $6.2402 \mathrm{E}-06$ & end \\
\hline$u-235$ & 115 & 0 & $4.8548 E-04$ & end \\
\hline$u-238$ & 115 & 0 & $2.2191 \mathrm{E}-02$ & end \\
\hline
\end{tabular}




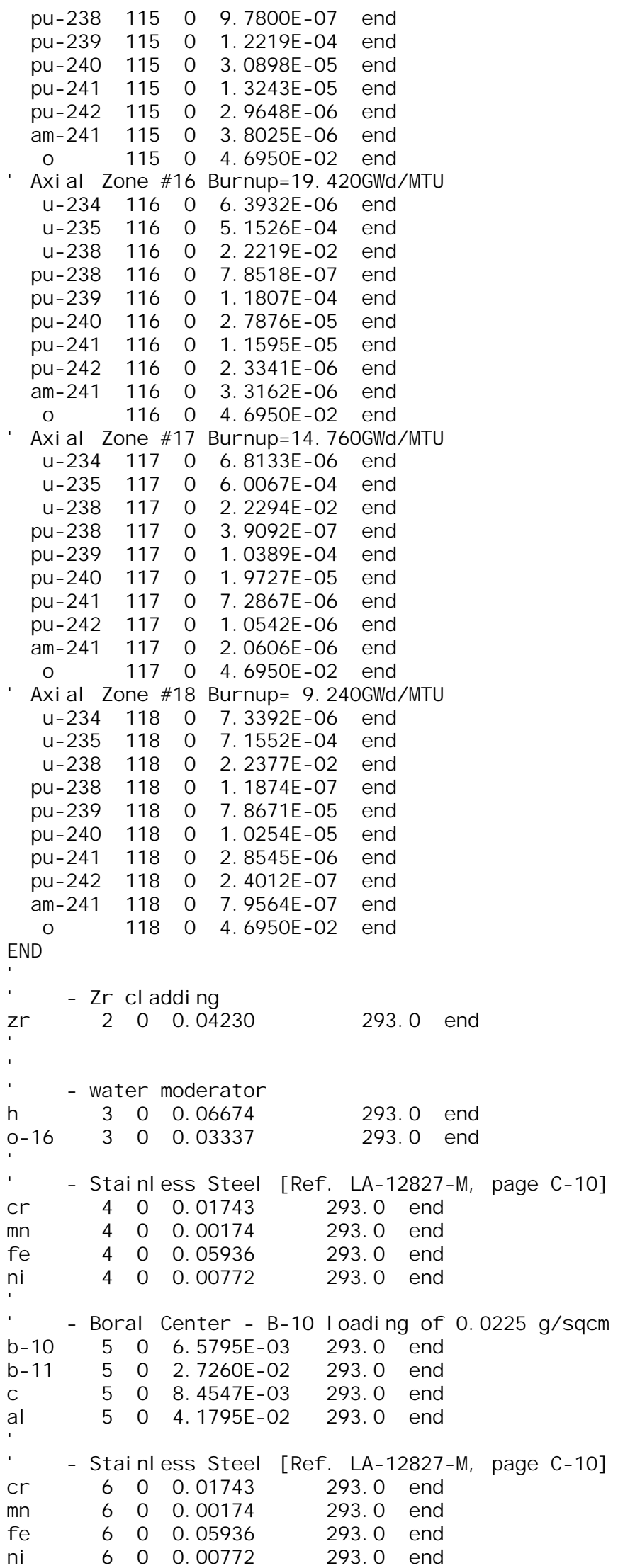




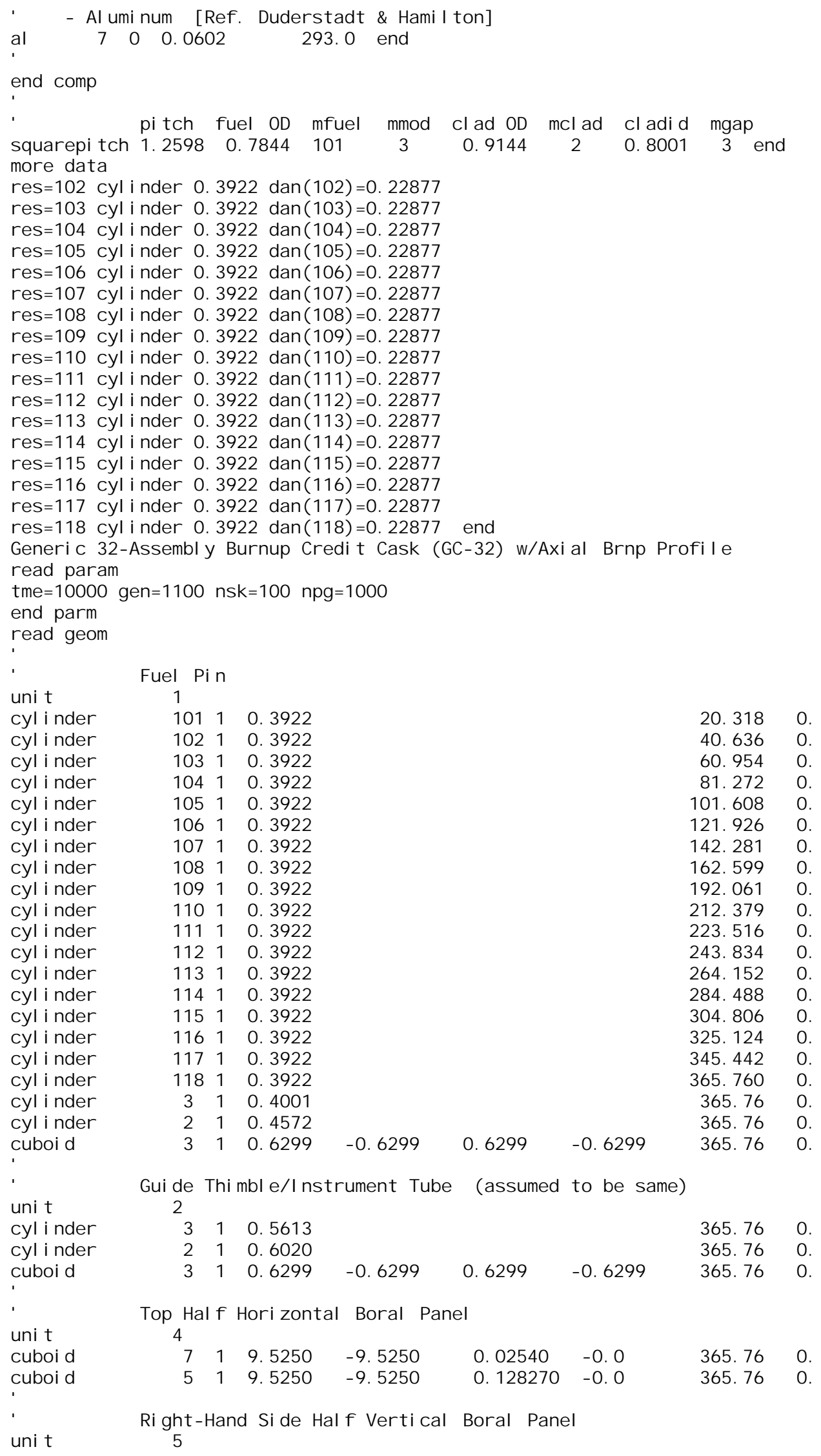




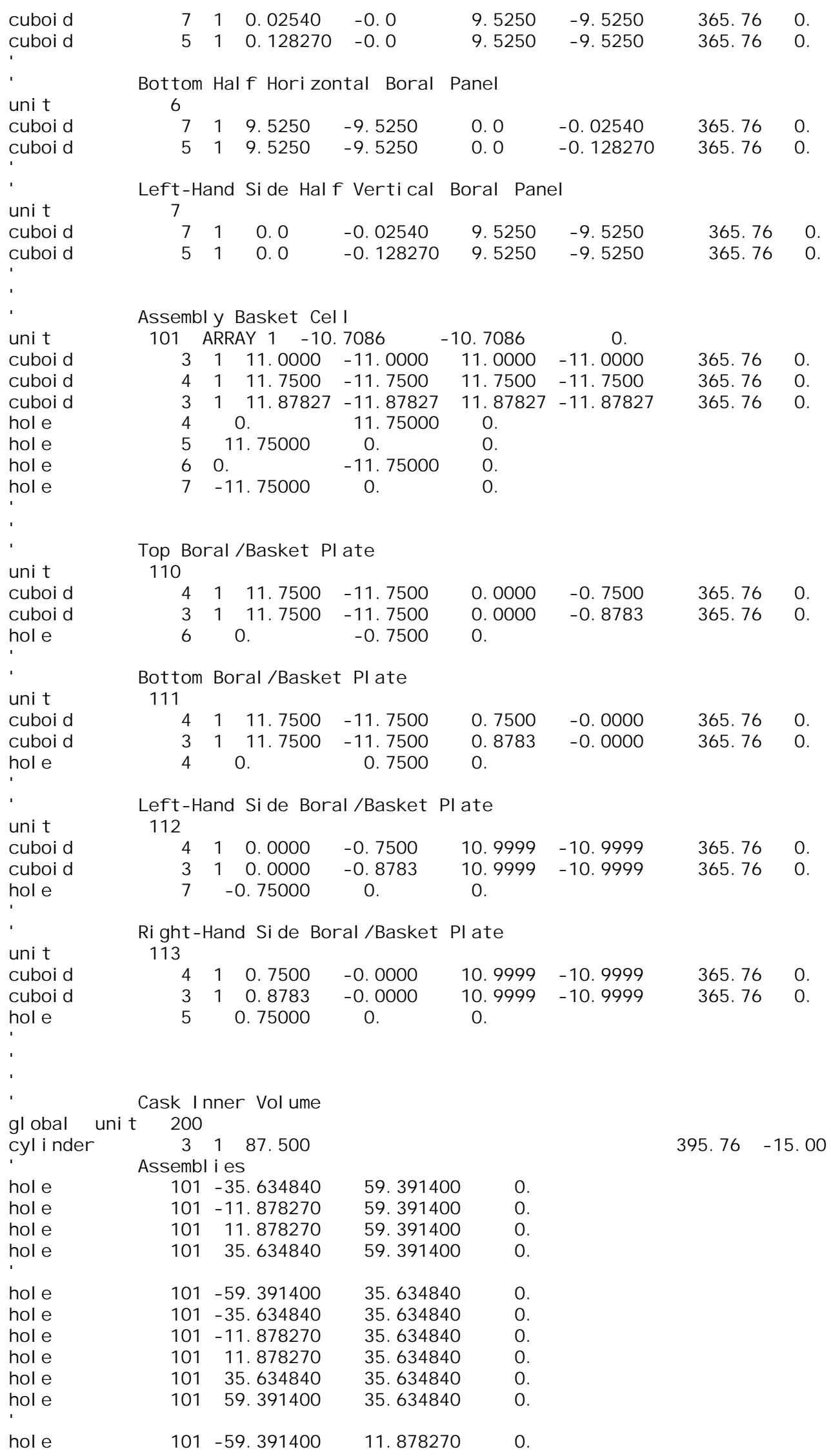




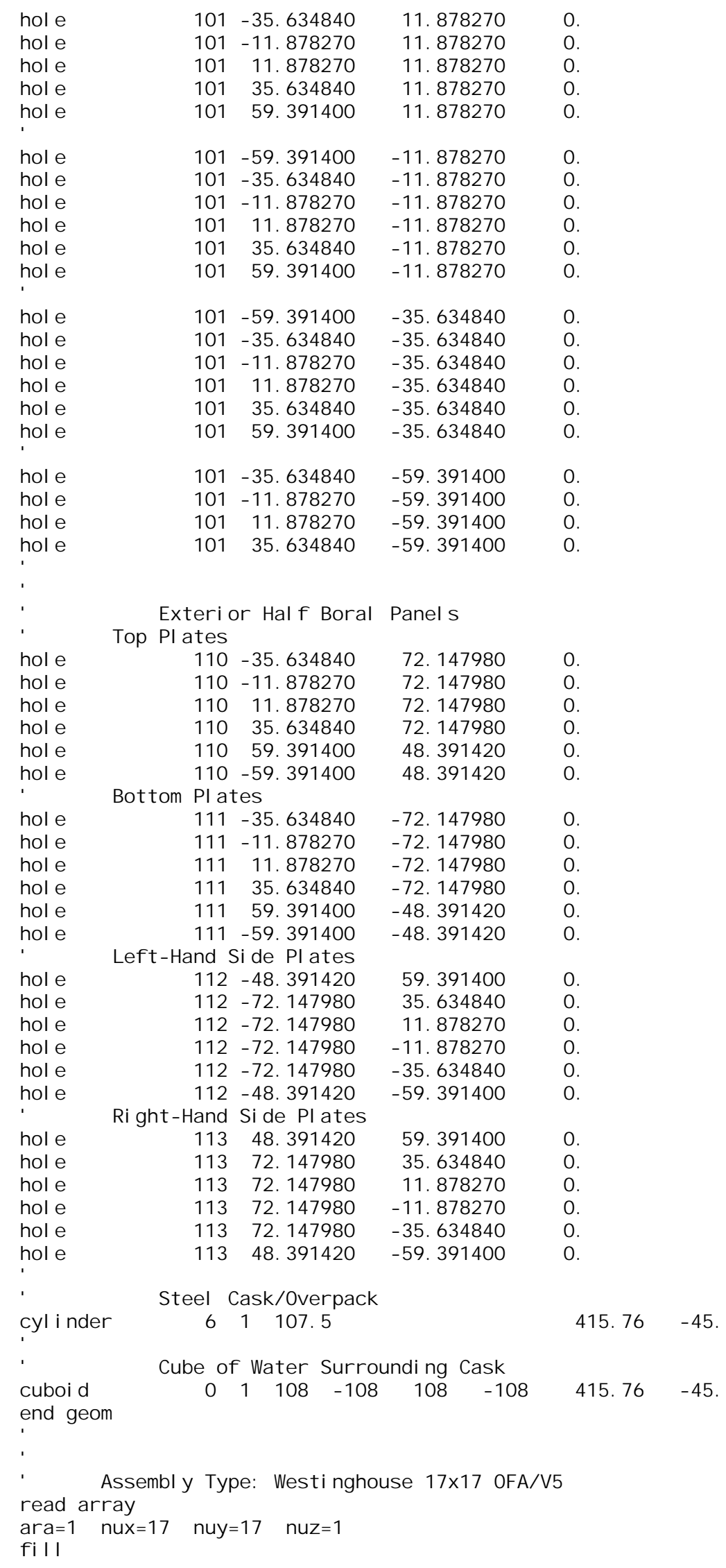




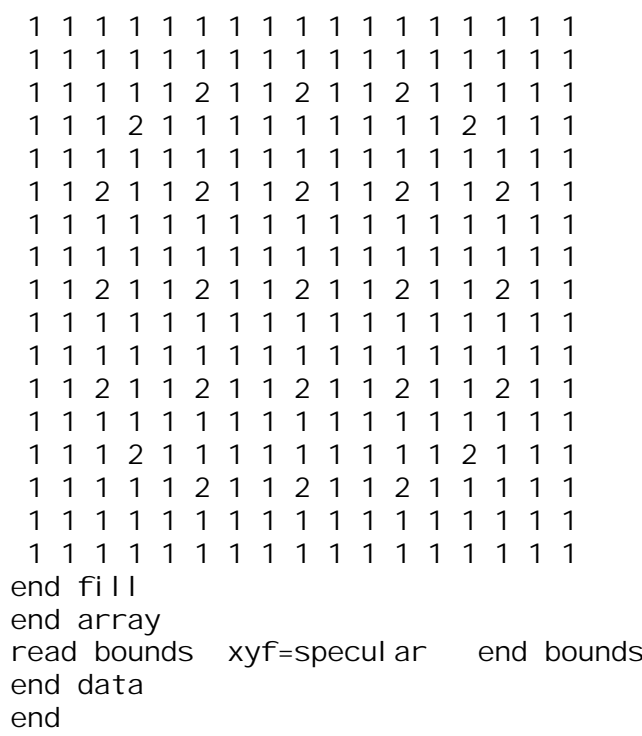


Sample 2: KRONOS KENO pin model, non-uniform axial profile, actinides + fission products, $40 \mathrm{GWd} / \mathrm{MTU}$

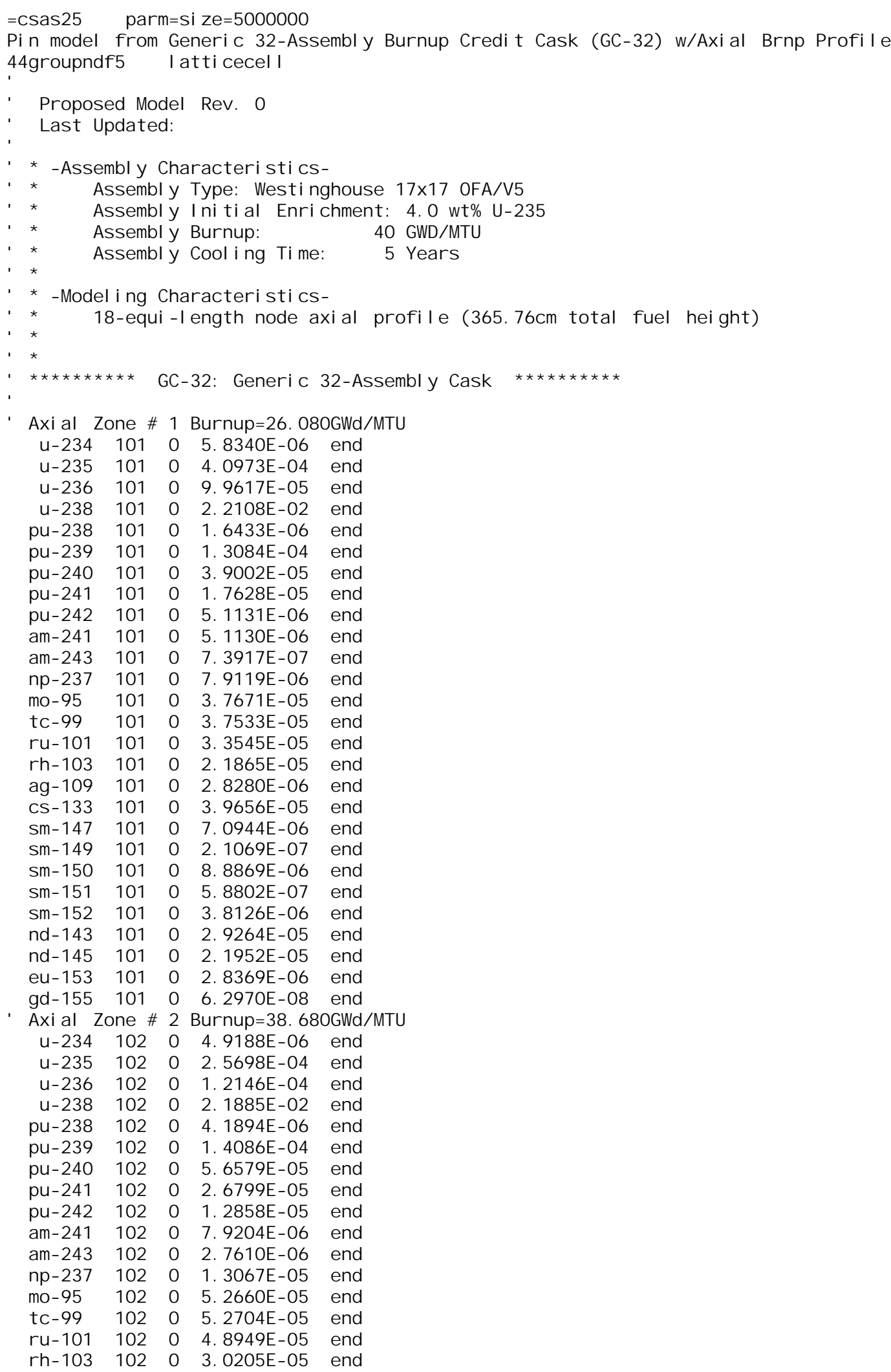




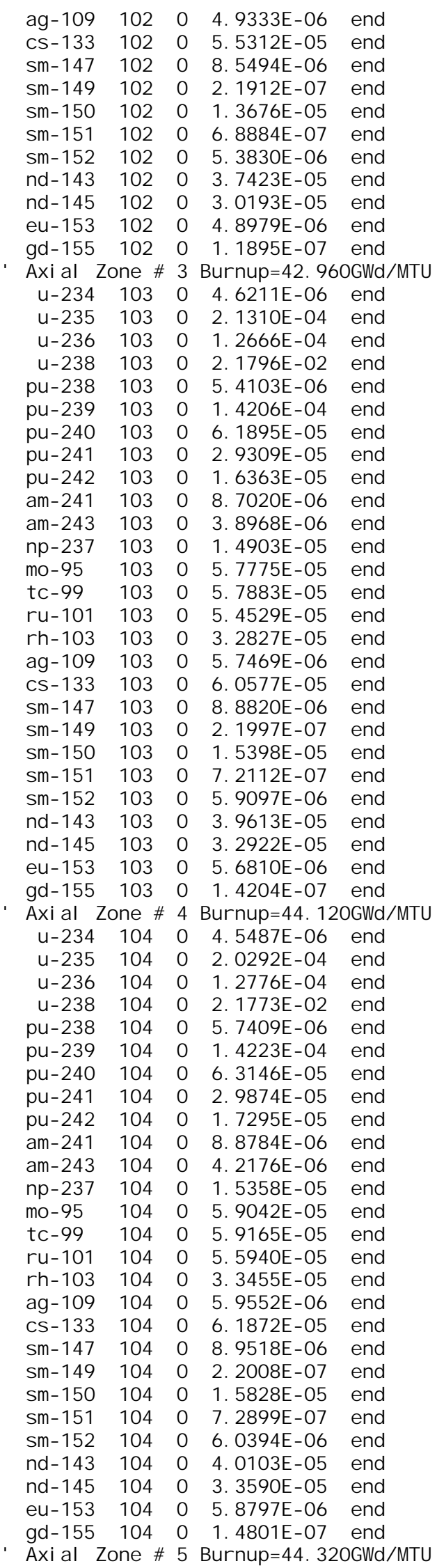




\begin{tabular}{|c|c|c|c|c|}
\hline$u-234$ & 105 & 0 & $4.5364 \mathrm{E}-06$ & end \\
\hline$u-235$ & 105 & 0 & 2. $0120 \mathrm{E}-04$ & end \\
\hline$u-236$ & 105 & 0 & 1. $2794 \mathrm{E}-04$ & end \\
\hline$u-238$ & 105 & 0 & $2.1769 \mathrm{E}-02$ & end \\
\hline$p u-238$ & 105 & 0 & $5.7986 \mathrm{E}-06$ & end \\
\hline$p u-239$ & 105 & 0 & 1. $4225 \mathrm{E}-04$ & end \\
\hline$p u-240$ & 105 & 0 & $6.3358 \mathrm{E}-05$ & end \\
\hline$p u-241$ & 105 & 0 & $2.9968 \mathrm{E}-05$ & end \\
\hline$p u-242$ & 105 & 0 & $1.7458 \mathrm{E}-05$ & end \\
\hline a m- 241 & 105 & 0 & $8.9078 \mathrm{E}-06$ & end \\
\hline a m- 243 & 105 & 0 & $4.2742 \mathrm{E}-06$ & end \\
\hline$n p-237$ & 105 & 0 & 1. $5435 \mathrm{E}-05$ & end \\
\hline mo- 95 & 105 & 0 & 5. $9260 \mathrm{E}-05$ & end \\
\hline t c -99 & 105 & 0 & 5. $9384 \mathrm{E}-05$ & end \\
\hline ru- 101 & 105 & 0 & $5.6182 \mathrm{E}-05$ & end \\
\hline$r h-103$ & 105 & 0 & $3.3562 \mathrm{E}-05$ & end \\
\hline ag -109 & 105 & 0 & 5. $9910 \mathrm{E}-06$ & end \\
\hline cs -133 & 105 & 0 & $6.2094 \mathrm{E}-05$ & end \\
\hline s m- 147 & 105 & 0 & $8.9633 \mathrm{E}-06$ & end \\
\hline s m- 149 & 105 & 0 & $2.2009 \mathrm{E}-07$ & end \\
\hline $\mathrm{sm}-150$ & 105 & 0 & $1.5902 \mathrm{E}-05$ & end \\
\hline s m- 151 & 105 & 0 & 7. $3033 \mathrm{E}-07$ & end \\
\hline s m- 152 & 105 & 0 & $6.0615 \mathrm{E}-06$ & end \\
\hline nd -143 & 105 & 0 & $4.0185 E-05$ & end \\
\hline nd -145 & 105 & 0 & $3.3705 \mathrm{E}-05$ & end \\
\hline eu- 153 & 105 & 0 & 5. $9139 E-06$ & end \\
\hline$g d-155$ & 105 & 0 & 1. $4904 \mathrm{E}-07$ & end \\
\hline Axial & Zone \# & 6 & Burnup $=44.2$ & O GWd / MTU \\
\hline$u-234$ & 106 & 0 & 4. $5413 E-06$ & end \\
\hline$u-235$ & 106 & 0 & $2.0188 \mathrm{E}-04$ & end \\
\hline$u-236$ & 106 & 0 & 1. $2787 \mathrm{E}-04$ & end \\
\hline$u-238$ & 106 & 0 & $2.1771 E-02$ & end \\
\hline$p u-238$ & 106 & 0 & $5.7756 \mathrm{E}-06$ & end \\
\hline$p u-239$ & 106 & 0 & 1. $4224 \mathrm{E}-04$ & end \\
\hline$p u-240$ & 106 & 0 & $6.3273 \mathrm{E}-05$ & end \\
\hline$p u-241$ & 106 & 0 & $2.9930 E-05$ & end \\
\hline$p u-242$ & 106 & 0 & $1.7393 \mathrm{E}-05$ & end \\
\hline a m- 241 & 106 & 0 & $8.8960 \mathrm{E}-06$ & end \\
\hline a m- 243 & 106 & 0 & $4.2515 E-06$ & end \\
\hline$n p-237$ & 106 & 0 & 1. $5404 \mathrm{E}-05$ & end \\
\hline mo- 95 & 106 & 0 & $5.9173 \mathrm{E}-05$ & end \\
\hline$t c-99$ & 106 & 0 & $5.9296 \mathrm{E}-05$ & end \\
\hline ru- 101 & 106 & 0 & $5.6085 E-05$ & end \\
\hline$r h-103$ & 106 & 0 & $3.3519 E-05$ & end \\
\hline $\mathrm{ag}-10 \mathrm{~g}$ & 106 & 0 & $5.9767 \mathrm{E}-06$ & end \\
\hline cs -133 & 106 & 0 & $6.2005 \mathrm{E}-05$ & end \\
\hline s m- 147 & 106 & 0 & $8.9587 \mathrm{E}-06$ & end \\
\hline s m- 149 & 106 & 0 & $2.2009 \mathrm{E}-07$ & end \\
\hline $\mathrm{sm}-150$ & 106 & 0 & 1. $5873 \mathrm{E}-05$ & end \\
\hline s m- 151 & 106 & 0 & 7. $2979 E-07$ & end \\
\hline s m- 152 & 106 & 0 & $6.0527 \mathrm{E}-06$ & end \\
\hline nd -143 & 106 & 0 & $4.0153 \mathrm{E}-05$ & end \\
\hline nd -145 & 106 & 0 & $3.3659 E-05$ & end \\
\hline eu- 153 & 106 & 0 & $5.9001 \mathrm{E}-06$ & end \\
\hline$g d-155$ & 106 & 0 & 1. $4863 \mathrm{E}-07$ & end \\
\hline Axial & Zone \# & 7 & Burnup $=44.0$ & O GWd / MTU \\
\hline$u-234$ & 107 & 0 & $4.5511 E-06$ & end \\
\hline$u-235$ & 107 & 0 & $2.0326 \mathrm{E}-04$ & end \\
\hline$u-236$ & 107 & 0 & 1. $2772 \mathrm{E}-04$ & end \\
\hline$u-238$ & 107 & 0 & $2.1774 \mathrm{E}-02$ & end \\
\hline$p u-238$ & 107 & 0 & $5.7294 \mathrm{E}-06$ & end \\
\hline$p u-239$ & 107 & 0 & 1. $4222 \mathrm{E}-04$ & end \\
\hline$p u-240$ & 107 & 0 & $6.3104 \mathrm{E}-05$ & end \\
\hline$p u-241$ & 107 & 0 & $2.9855 \mathrm{E}-05$ & end \\
\hline$p u-242$ & 107 & 0 & $1.7263 \mathrm{E}-05$ & end \\
\hline a m- 241 & 107 & 0 & $8.8725 \mathrm{E}-06$ & end \\
\hline a m- 243 & 107 & 0 & $4.2063 E-06$ & end \\
\hline$n p-237$ & 107 & 0 & 1. $5342 \mathrm{E}-05$ & end \\
\hline
\end{tabular}




\begin{tabular}{|c|c|c|c|c|}
\hline mo- 95 & 107 & 0 & 5. $8999 \mathrm{E}-05$ & end \\
\hline$t c-99$ & 107 & 0 & $5.9121 \mathrm{E}-05$ & end \\
\hline$r u-101$ & 107 & 0 & 5. $5891 \mathrm{E}-05$ & end \\
\hline$r h-103$ & 107 & 0 & 3. $3434 \mathrm{E}-05$ & end \\
\hline ag- 109 & 107 & 0 & 5. $9480 \mathrm{E}-06$ & end \\
\hline cs -133 & 107 & 0 & $6.1828 \mathrm{E}-05$ & end \\
\hline s m- 147 & 107 & 0 & $8.9495 E-06$ & end \\
\hline s m- 149 & 107 & 0 & $2.2008 \mathrm{E}-07$ & end \\
\hline $\mathrm{sm}-150$ & 107 & 0 & 1. $5814 \mathrm{E}-05$ & end \\
\hline s m- 151 & 107 & 0 & 7. $2872 \mathrm{E}-07$ & end \\
\hline s m- 152 & 107 & 0 & $6.0349 \mathrm{E}-06$ & end \\
\hline nd -143 & 107 & 0 & $4.0087 \mathrm{E}-05$ & end \\
\hline nd -145 & 107 & 0 & $3.3568 E-05$ & end \\
\hline eu- 153 & 107 & 0 & $5.8728 \mathrm{E}-06$ & end \\
\hline$g d-155$ & 107 & 0 & 1. $4781 \mathrm{E}-07$ & end \\
\hline Axial & one \# & 8 & Burnup $=43.8$ & O GWd / MT U \\
\hline$u-234$ & 108 & 0 & $4.5635 \mathrm{E}-06$ & end \\
\hline$u-235$ & 108 & 0 & $2.0499 E-04$ & end \\
\hline$u-236$ & 108 & 0 & 1. $2754 \mathrm{E}-04$ & end \\
\hline$u-238$ & 108 & 0 & $2.1778 \mathrm{E}-02$ & end \\
\hline$p u-238$ & 108 & 0 & $5.6719 \mathrm{E}-06$ & end \\
\hline$p u-239$ & 108 & 0 & 1. $4219 \mathrm{E}-04$ & end \\
\hline$p u-240$ & 108 & 0 & $6.2891 \mathrm{E}-05$ & end \\
\hline$p u-241$ & 108 & 0 & $2.9759 E-05$ & end \\
\hline$p u-242$ & 108 & 0 & $1.7101 \mathrm{E}-05$ & end \\
\hline a m- 241 & 108 & 0 & $8.8425 \mathrm{E}-06$ & end \\
\hline a m- 243 & 108 & 0 & $4.1502 E-06$ & end \\
\hline$n p-237$ & 108 & 0 & 1. $5264 \mathrm{E}-05$ & end \\
\hline mo- 95 & 108 & 0 & $5.8781 \mathrm{E}-05$ & end \\
\hline$t c-99$ & 108 & 0 & $5.8901 \mathrm{E}-05$ & end \\
\hline ru- 101 & 108 & 0 & 5. $5648 \mathrm{E}-05$ & end \\
\hline$r h-103$ & 108 & 0 & $3.3326 \mathrm{E}-05$ & end \\
\hline ag- 109 & 108 & 0 & $5.9120 \mathrm{E}-06$ & end \\
\hline cs -133 & 108 & 0 & $6.1605 \mathrm{E}-05$ & end \\
\hline s m- 147 & 108 & 0 & $8.9378 \mathrm{E}-06$ & end \\
\hline s m- 149 & 108 & 0 & $2.2006 \mathrm{E}-07$ & end \\
\hline $\mathrm{sm}-150$ & 108 & 0 & 1. $5740 \mathrm{E}-05$ & end \\
\hline s m- 151 & 108 & 0 & $7.2737 \mathrm{E}-07$ & end \\
\hline s m- 152 & 108 & 0 & $6.0127 \mathrm{E}-06$ & end \\
\hline nd -143 & 108 & 0 & $4.0004 \mathrm{E}-05$ & end \\
\hline nd -145 & 108 & 0 & 3. $3453 \mathrm{E}-05$ & end \\
\hline eu- 153 & 108 & 0 & $5.8387 \mathrm{E}-06$ & end \\
\hline$g d-155$ & 108 & 0 & 1. $4678 \mathrm{E}-07$ & end \\
\hline Axial & one \# & 9 & Burnup $=43.7$ & O GWd / MT U \\
\hline$u-234$ & 109 & 0 & $4.5923 \mathrm{E}-06$ & end \\
\hline$u-235$ & 109 & 0 & 2. $0904 \mathrm{E}-04$ & end \\
\hline$u-236$ & 109 & 0 & 1. $2710 \mathrm{E}-04$ & end \\
\hline$u-238$ & 109 & 0 & $2.1787 \mathrm{E}-02$ & end \\
\hline$p u-238$ & 109 & 0 & $5.5398 \mathrm{E}-06$ & end \\
\hline$p u-239$ & 109 & 0 & 1. $4213 \mathrm{E}-04$ & end \\
\hline$p u-240$ & 109 & 0 & $6.2394 \mathrm{E}-05$ & end \\
\hline$p u-241$ & 109 & 0 & $2.9535 \mathrm{E}-05$ & end \\
\hline$p u-242$ & 109 & 0 & $1.6729 \mathrm{E}-05$ & end \\
\hline a m- 241 & 109 & 0 & $8.7726 \mathrm{E}-06$ & end \\
\hline a m- 243 & 109 & 0 & $4.0218 E-06$ & end \\
\hline$n p-237$ & 109 & 0 & 1. $5083 \mathrm{E}-05$ & end \\
\hline mo- 95 & 109 & 0 & $5.8276 \mathrm{E}-05$ & end \\
\hline$t c-99$ & 109 & 0 & $5.8390 E-05$ & end \\
\hline ru- 101 & 109 & 0 & $5.5086 \mathrm{E}-05$ & end \\
\hline$r h-103$ & 109 & 0 & $3.3077 \mathrm{E}-05$ & end \\
\hline ag- 109 & 109 & 0 & $5.8289 E-06$ & end \\
\hline cs -133 & 109 & 0 & $6.1089 \mathrm{E}-05$ & end \\
\hline s m- 147 & 109 & 0 & $8.9102 \mathrm{E}-06$ & end \\
\hline s m- 149 & 109 & 0 & $2.2002 \mathrm{E}-07$ & end \\
\hline s m- 150 & 109 & 0 & 1. $5568 \mathrm{E}-05$ & end \\
\hline s m- 151 & 109 & 0 & 7. $2424 \mathrm{E}-07$ & end \\
\hline s m- 152 & 109 & 0 & $5.9610 \mathrm{E}-06$ & end \\
\hline nd -143 & 109 & 0 & $3.9809 \mathrm{E}-05$ & end \\
\hline
\end{tabular}




\begin{tabular}{|c|c|c|c|c|}
\hline nd -145 & 109 & 0 & $3.3187 \mathrm{E}-05$ & end \\
\hline eu- 153 & 109 & 0 & $5.7594 \mathrm{E}-06$ & end \\
\hline$g d-155$ & 109 & 0 & 1. $4439 \mathrm{E}-07$ & end \\
\hline Axial & Zone & \#10 & Burnup $=43.76$ & O GWd / MT U \\
\hline$u-234$ & 110 & 0 & $4.5923 \mathrm{E}-06$ & end \\
\hline$u-235$ & 110 & 0 & 2. $0904 \mathrm{E}-04$ & end \\
\hline$u-236$ & 110 & 0 & 1. $2710 \mathrm{E}-04$ & end \\
\hline$u-238$ & 110 & 0 & $2.1787 \mathrm{E}-02$ & end \\
\hline$p u-238$ & 110 & 0 & $5.5398 \mathrm{E}-06$ & end \\
\hline$p u-239$ & 110 & 0 & 1. $4213 \mathrm{E}-04$ & end \\
\hline$p u-240$ & 110 & 0 & $6.2394 \mathrm{E}-05$ & end \\
\hline$p u-241$ & 110 & 0 & $2.9535 \mathrm{E}-05$ & end \\
\hline$p u-242$ & 110 & 0 & $1.6729 \mathrm{E}-05$ & end \\
\hline a m- 241 & 110 & 0 & $8.7726 \mathrm{E}-06$ & end \\
\hline a m- 243 & 110 & 0 & $4.0218 \mathrm{E}-06$ & end \\
\hline$n p-237$ & 110 & 0 & 1. $5083 \mathrm{E}-05$ & end \\
\hline mo- 95 & 110 & 0 & $5.8276 \mathrm{E}-05$ & end \\
\hline$t c-99$ & 110 & 0 & $5.8390 \mathrm{E}-05$ & end \\
\hline$r u-101$ & 110 & 0 & 5. $5086 \mathrm{E}-05$ & end \\
\hline$r h-103$ & 110 & 0 & $3.3077 \mathrm{E}-05$ & end \\
\hline ag- 109 & 110 & 0 & $5.8289 \mathrm{E}-06$ & end \\
\hline Cs -133 & 110 & 0 & $6.1089 \mathrm{E}-05$ & end \\
\hline s m- 147 & 110 & 0 & $8.9102 \mathrm{E}-06$ & end \\
\hline s m- 149 & 110 & 0 & $2.2002 \mathrm{E}-07$ & end \\
\hline s m- 150 & 110 & 0 & 1. $5568 \mathrm{E}-05$ & end \\
\hline s m- 151 & 110 & 0 & 7. $2424 \mathrm{E}-07$ & end \\
\hline s m- 152 & 110 & 0 & 5. $9610 \mathrm{E}-06$ & end \\
\hline nd -143 & 110 & 0 & $3.9809 \mathrm{E}-05$ & end \\
\hline nd -145 & 110 & 0 & $3.3187 \mathrm{E}-05$ & end \\
\hline eu- 153 & 110 & 0 & $5.7594 \mathrm{E}-06$ & end \\
\hline$g d-155$ & 110 & 0 & 1. $4439 \mathrm{E}-07$ & end \\
\hline Axial & Zone & \#11 & Burnup $=43.80$ & $0 \mathrm{GWd} / \mathrm{MT} \mathrm{U}$ \\
\hline$u-234$ & 111 & 0 & $4.5923 \mathrm{E}-06$ & end \\
\hline$u-235$ & 111 & 0 & 2. $0904 \mathrm{E}-04$ & end \\
\hline$u-236$ & 111 & 0 & 1. $2710 \mathrm{E}-04$ & end \\
\hline$u-238$ & 111 & 0 & $2.1787 \mathrm{E}-02$ & end \\
\hline$p u-238$ & 111 & 0 & $5.5398 \mathrm{E}-06$ & end \\
\hline$p u-239$ & 111 & 0 & 1. $4213 \mathrm{E}-04$ & end \\
\hline$p u-240$ & 111 & 0 & $6.2394 \mathrm{E}-05$ & end \\
\hline$p u-241$ & 111 & 0 & $2.9535 \mathrm{E}-05$ & end \\
\hline$p u-242$ & 111 & 0 & $1.6729 \mathrm{E}-05$ & end \\
\hline a m- 241 & 111 & 0 & $8.7726 \mathrm{E}-06$ & end \\
\hline a m- 243 & 111 & 0 & $4.0218 \mathrm{E}-06$ & end \\
\hline$n p-237$ & 111 & 0 & 1. $5083 \mathrm{E}-05$ & end \\
\hline mo- 95 & 111 & 0 & $5.8276 \mathrm{E}-05$ & end \\
\hline tc -99 & 111 & 0 & $5.8390 \mathrm{E}-05$ & end \\
\hline$r u-101$ & 111 & 0 & 5. $5086 \mathrm{E}-05$ & end \\
\hline$r h-103$ & 111 & 0 & $3.3077 \mathrm{E}-05$ & end \\
\hline ag- 109 & 111 & 0 & $5.8289 \mathrm{E}-06$ & end \\
\hline cs -133 & 111 & 0 & $6.1089 \mathrm{E}-05$ & end \\
\hline s m- 147 & 111 & 0 & $8.9102 \mathrm{E}-06$ & end \\
\hline s m- 149 & 111 & 0 & $2.2002 \mathrm{E}-07$ & end \\
\hline s m- 150 & 111 & 0 & $1.5568 \mathrm{E}-05$ & end \\
\hline s m- 151 & 111 & 0 & 7. $2424 \mathrm{E}-07$ & end \\
\hline s m- 152 & 111 & 0 & 5. $9610 \mathrm{E}-06$ & end \\
\hline nd -143 & 111 & 0 & $3.9809 \mathrm{E}-05$ & end \\
\hline nd -145 & 111 & 0 & $3.3187 \mathrm{E}-05$ & end \\
\hline eu- 153 & 111 & 0 & $5.7594 \mathrm{E}-06$ & end \\
\hline$g d-155$ & 111 & 0 & 1. $4439 \mathrm{E}-07$ & end \\
\hline Axial & Zone & \#12 & Burnup $=43.84$ & $0 \mathrm{GWd} / \mathrm{MT} \mathrm{U}$ \\
\hline$u-234$ & 112 & 0 & $4.5923 E-06$ & end \\
\hline$u-235$ & 112 & 0 & $2.0904 \mathrm{E}-04$ & end \\
\hline$u-236$ & 112 & 0 & 1. $2710 \mathrm{E}-04$ & end \\
\hline$u-238$ & 112 & 0 & $2.1787 \mathrm{E}-02$ & end \\
\hline$p u-238$ & 112 & 0 & $5.5398 E-06$ & end \\
\hline$p u-239$ & 112 & 0 & 1. $4213 \mathrm{E}-04$ & end \\
\hline$p u-240$ & 112 & 0 & $6.2394 \mathrm{E}-05$ & end \\
\hline$p u-241$ & 112 & 0 & $2.9535 E-05$ & end \\
\hline
\end{tabular}




\begin{tabular}{|c|c|c|c|c|}
\hline$p u-242$ & 112 & 0 & $1.6729 \mathrm{E}-05$ & end \\
\hline a m- 241 & 112 & 0 & $8.7726 \mathrm{E}-06$ & end \\
\hline a m- 243 & 112 & 0 & $4.0218 \mathrm{E}-06$ & end \\
\hline$n p-237$ & 112 & 0 & 1. $5083 \mathrm{E}-05$ & end \\
\hline mo- 95 & 112 & 0 & $5.8276 \mathrm{E}-05$ & end \\
\hline tc -99 & 112 & 0 & $5.8390 \mathrm{E}-05$ & end \\
\hline r u- 101 & 112 & 0 & $5.5086 \mathrm{E}-05$ & end \\
\hline$r h-103$ & 112 & 0 & $3.3077 \mathrm{E}-05$ & end \\
\hline ag- 109 & 112 & 0 & $5.8289 \mathrm{E}-06$ & end \\
\hline cs -133 & 112 & 0 & $6.1089 \mathrm{E}-05$ & end \\
\hline s m- 147 & 112 & 0 & $8.9102 \mathrm{E}-06$ & end \\
\hline s m- 149 & 112 & 0 & $2.2002 \mathrm{E}-07$ & end \\
\hline s m- 150 & 112 & 0 & 1. $5568 \mathrm{E}-05$ & end \\
\hline s m- 151 & 112 & 0 & 7. $2424 \mathrm{E}-07$ & end \\
\hline s m- 152 & 112 & 0 & $5.9610 \mathrm{E}-06$ & end \\
\hline nd -143 & 112 & 0 & $3.9809 \mathrm{E}-05$ & end \\
\hline nd -145 & 112 & 0 & $3.3187 \mathrm{E}-05$ & end \\
\hline eu- 153 & 112 & 0 & $5.7594 \mathrm{E}-06$ & end \\
\hline$g d-155$ & 112 & 0 & 1. $4439 \mathrm{E}-07$ & end \\
\hline Axial & one & $\$ 13$ & Burnup $=43.8$ & 0 GWd / MT U \\
\hline$u-234$ & 113 & 0 & $4.5923 \mathrm{E}-06$ & end \\
\hline$u-235$ & 113 & 0 & 2. $0904 \mathrm{E}-04$ & end \\
\hline$u-236$ & 113 & 0 & 1. $2710 \mathrm{E}-04$ & end \\
\hline$u-238$ & 113 & 0 & $2.1787 \mathrm{E}-02$ & end \\
\hline$p u-238$ & 113 & 0 & $5.5398 \mathrm{E}-06$ & end \\
\hline$p u-239$ & 113 & 0 & 1. $4213 \mathrm{E}-04$ & end \\
\hline$p u-240$ & 113 & 0 & $6.2394 \mathrm{E}-05$ & end \\
\hline pu- 241 & 113 & 0 & $2.9535 \mathrm{E}-05$ & end \\
\hline$p u-242$ & 113 & 0 & $1.6729 \mathrm{E}-05$ & end \\
\hline a m- 241 & 113 & 0 & $8.7726 \mathrm{E}-06$ & end \\
\hline a m- 243 & 113 & 0 & $4.0218 \mathrm{E}-06$ & end \\
\hline$n p-237$ & 113 & 0 & 1. $5083 \mathrm{E}-05$ & end \\
\hline mo- 95 & 113 & 0 & $5.8276 \mathrm{E}-05$ & end \\
\hline tc -99 & 113 & 0 & $5.8390 \mathrm{E}-05$ & end \\
\hline$r u-101$ & 113 & 0 & $5.5086 \mathrm{E}-05$ & end \\
\hline$r h-103$ & 113 & 0 & $3.3077 \mathrm{E}-05$ & end \\
\hline ag- 109 & 113 & 0 & $5.8289 \mathrm{E}-06$ & end \\
\hline cs -133 & 113 & 0 & $6.1089 \mathrm{E}-05$ & end \\
\hline s m- 147 & 113 & 0 & $8.9102 \mathrm{E}-06$ & end \\
\hline s m- 149 & 113 & 0 & $2.2002 \mathrm{E}-07$ & end \\
\hline s m- 150 & 113 & 0 & 1. $5568 \mathrm{E}-05$ & end \\
\hline s m- 151 & 113 & 0 & 7. $2424 \mathrm{E}-07$ & end \\
\hline s m- 152 & 113 & 0 & $5.9610 \mathrm{E}-06$ & end \\
\hline nd -143 & 113 & 0 & $3.9809 \mathrm{E}-05$ & end \\
\hline nd -145 & 113 & 0 & $3.3187 \mathrm{E}-05$ & end \\
\hline eu- 153 & 113 & 0 & $5.7594 \mathrm{E}-06$ & end \\
\hline $\mathrm{gd}-155$ & 113 & 0 & 1. $4439 \mathrm{E}-07$ & end \\
\hline Axial & one & \#14 & Burnup $=43.4$ & 0 GWd / MT U \\
\hline$u-234$ & 114 & 0 & $4.5923 \mathrm{E}-06$ & end \\
\hline$u-235$ & 114 & 0 & $2.0904 \mathrm{E}-04$ & end \\
\hline$u-236$ & 114 & 0 & 1. $2710 \mathrm{E}-04$ & end \\
\hline$u-238$ & 114 & 0 & $2.1787 \mathrm{E}-02$ & end \\
\hline$p u-238$ & 114 & 0 & $5.5398 \mathrm{E}-06$ & end \\
\hline$p u-239$ & 114 & 0 & 1. $4213 \mathrm{E}-04$ & end \\
\hline$p u-240$ & 114 & 0 & $6.2394 \mathrm{E}-05$ & end \\
\hline$p u-241$ & 114 & 0 & $2.9535 \mathrm{E}-05$ & end \\
\hline$p u-242$ & 114 & 0 & $1.6729 \mathrm{E}-05$ & end \\
\hline a m- 241 & 114 & 0 & $8.7726 \mathrm{E}-06$ & end \\
\hline a m- 243 & 114 & 0 & $4.0218 \mathrm{E}-06$ & end \\
\hline$n p-237$ & 114 & 0 & $1.5083 \mathrm{E}-05$ & end \\
\hline mo- 95 & 114 & 0 & $5.8276 \mathrm{E}-05$ & end \\
\hline$t c-99$ & 114 & 0 & $5.8390 \mathrm{E}-05$ & end \\
\hline$r u-101$ & 114 & 0 & $5.5086 \mathrm{E}-05$ & end \\
\hline$r h-103$ & 114 & 0 & $3.3077 \mathrm{E}-05$ & end \\
\hline ag- 109 & 114 & 0 & $5.8289 \mathrm{E}-06$ & end \\
\hline cs -133 & 114 & 0 & $6.1089 \mathrm{E}-05$ & end \\
\hline s m- 147 & 114 & 0 & $8.9102 \mathrm{E}-06$ & end \\
\hline s m- 149 & 114 & 0 & $2.2002 \mathrm{E}-07$ & end \\
\hline
\end{tabular}




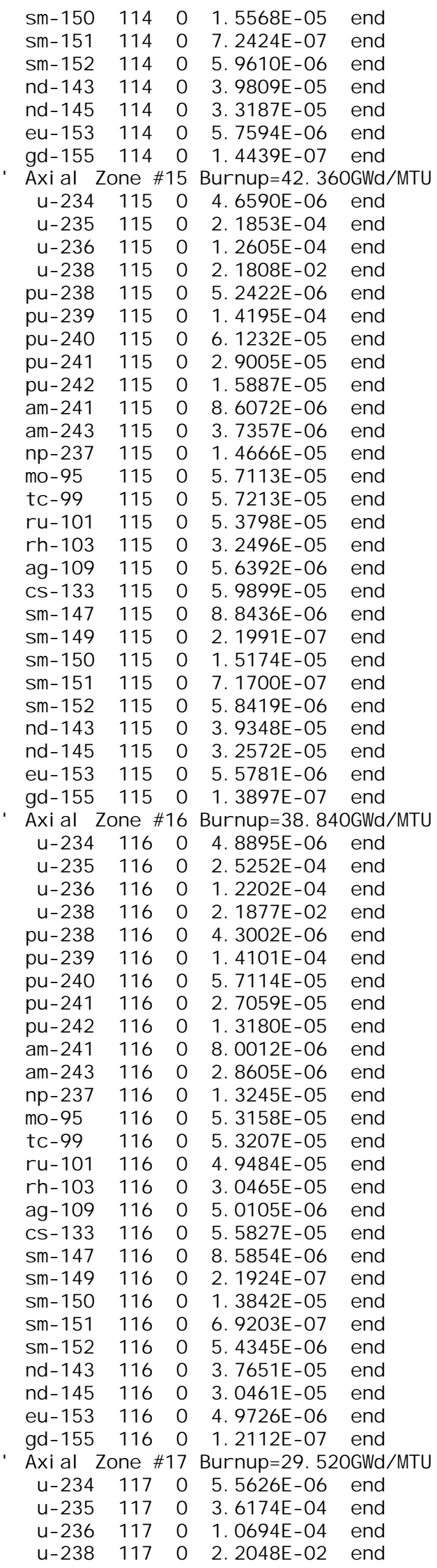




\begin{tabular}{|c|c|c|c|c|}
\hline$p u-238$ & 117 & 0 & $2.2316 E-06$ & end \\
\hline$p u-239$ & 117 & 0 & 1. $3500 E-04$ & end \\
\hline$p u-240$ & 117 & 0 & $4.4351 E-05$ & end \\
\hline$p u-241$ & 117 & 0 & $2.0518 E-05$ & end \\
\hline$p u-242$ & 117 & 0 & $6.9686 E-06$ & end \\
\hline a m- 241 & 117 & 0 & $5.9884 E-06$ & end \\
\hline a m- 243 & 117 & 0 & 1. $1495 \mathrm{E}-06$ & end \\
\hline$n p-237$ & 117 & 0 & $9.3498 E-06$ & end \\
\hline mo- 95 & 117 & 0 & $4.2027 \mathrm{E}-05$ & end \\
\hline$t c-99$ & 117 & 0 & $4.1935 E-05$ & end \\
\hline ru- 101 & 117 & 0 & $3.7885 E-05$ & end \\
\hline$r h-103$ & 117 & 0 & $2.4369 E-05$ & end \\
\hline $\mathrm{ag}-109$ & 117 & 0 & $3.3938 E-06$ & end \\
\hline Cs -133 & 117 & 0 & $4.4229 E-05$ & end \\
\hline s m- 147 & 117 & 0 & $7.5922 \mathrm{E}-06$ & end \\
\hline s m- 149 & 117 & 0 & $2.1422 \mathrm{E}-07$ & end \\
\hline s m- 150 & 117 & 0 & 1. $0229 E-05$ & end \\
\hline s m- 151 & 117 & 0 & $6.1836 \mathrm{E}-07$ & end \\
\hline s m- 152 & 117 & 0 & $4.2733 E-06$ & end \\
\hline nd - 143 & 117 & 0 & $3.1881 E-05$ & end \\
\hline nd -145 & 117 & 0 & $2.4379 E-05$ & end \\
\hline eu- 153 & 117 & 0 & $3.3935 E-06$ & end \\
\hline$g d-155$ & 117 & 0 & $7.7217 \mathrm{E}-08$ & end \\
\hline Axial Z & one & 18 & Burnup $=18.48$ & O GWd / MT U \\
\hline$u-234$ & 118 & 0 & $6.4886 \mathrm{E}-06$ & end \\
\hline$u-235$ & 118 & 0 & 5. $3420 \mathrm{E}-04$ & end \\
\hline$u-236$ & 118 & 0 & $7.9326 \mathrm{E}-05$ & end \\
\hline$u-238$ & 118 & 0 & $2.2237 \mathrm{E}-02$ & end \\
\hline$p u-238$ & 118 & 0 & $6.7916 \mathrm{E}-07$ & end \\
\hline$p u-239$ & 118 & 0 & 1. $1528 \mathrm{E}-04$ & end \\
\hline$p u-240$ & 118 & 0 & $2.6025 E-05$ & end \\
\hline$p u-241$ & 118 & 0 & $1.0558 \mathrm{E}-05$ & end \\
\hline$p u-242$ & 118 & 0 & $1.9856 \mathrm{E}-06$ & end \\
\hline a m- 241 & 118 & 0 & $3.0123 \mathrm{E}-06$ & end \\
\hline a m- 243 & 118 & 0 & 1. $9430 \mathrm{E}-07$ & end \\
\hline$n p-237$ & 118 & 0 & $4.8310 \mathrm{E}-06$ & end \\
\hline mo- 95 & 118 & 0 & $2.7393 E-05$ & end \\
\hline tc $c-99$ & 118 & 0 & $2.7188 \mathrm{E}-05$ & end \\
\hline ru- 101 & 118 & 0 & $2.3708 E-05$ & end \\
\hline$r h-103$ & 118 & 0 & 1. $5795 \mathrm{E}-05$ & end \\
\hline $\mathrm{ag}-109$ & 118 & 0 & $1.6590 \mathrm{E}-06$ & end \\
\hline Cs -133 & 118 & 0 & $2.8824 \mathrm{E}-05$ & end \\
\hline s m- 147 & 118 & 0 & $5.6700 \mathrm{E}-06$ & end \\
\hline s m- 149 & 118 & 0 & $1.9789 \mathrm{E}-07$ & end \\
\hline s m- 150 & 118 & 0 & 5. $9210 \mathrm{E}-06$ & end \\
\hline s m- 151 & 118 & 0 & 5. $1262 E-07$ & end \\
\hline s m- 152 & 118 & 0 & $2.7095 E-06$ & end \\
\hline nd - 143 & 118 & 0 & $2.2392 E-05$ & end \\
\hline nd -145 & 118 & 0 & $1.6130 \mathrm{E}-05$ & end \\
\hline eu- 153 & 118 & 0 & $1.6900 \mathrm{E}-06$ & end \\
\hline $\begin{array}{l}g d-155 \\
D\end{array}$ & 118 & 0 & $3.6424 \mathrm{E}-08$ & end \\
\hline 0 & 101 & 0 & $4.6950 E-02$ & end \\
\hline 0 & 102 & 0 & $4.6950 \mathrm{E}-02$ & end \\
\hline 0 & 103 & 0 & $4.6950 \mathrm{E}-02$ & end \\
\hline 0 & 104 & 0 & $4.6950 \mathrm{E}-02$ & end \\
\hline 0 & 105 & 0 & $4.6950 E-02$ & end \\
\hline 0 & 106 & 0 & $4.6950 E-02$ & end \\
\hline 0 & 107 & 0 & $4.6950 E-02$ & end \\
\hline 0 & 108 & 0 & $4.6950 \mathrm{E}-02$ & end \\
\hline 0 & 109 & 0 & $4.6950 \mathrm{E}-02$ & end \\
\hline 0 & 110 & 0 & $4.6950 E-02$ & end \\
\hline 0 & 111 & 0 & $4.6950 \mathrm{E}-02$ & end \\
\hline 0 & 112 & 0 & $4.6950 E-02$ & end \\
\hline 0 & 113 & 0 & $4.6950 \mathrm{E}-02$ & end \\
\hline 0 & 114 & 0 & $4.6950 E-02$ & end \\
\hline 0 & 115 & 0 & $4.6950 E-02$ & end \\
\hline 0 & 116 & 0 & $4.6950 \mathrm{E}-02$ & end \\
\hline
\end{tabular}




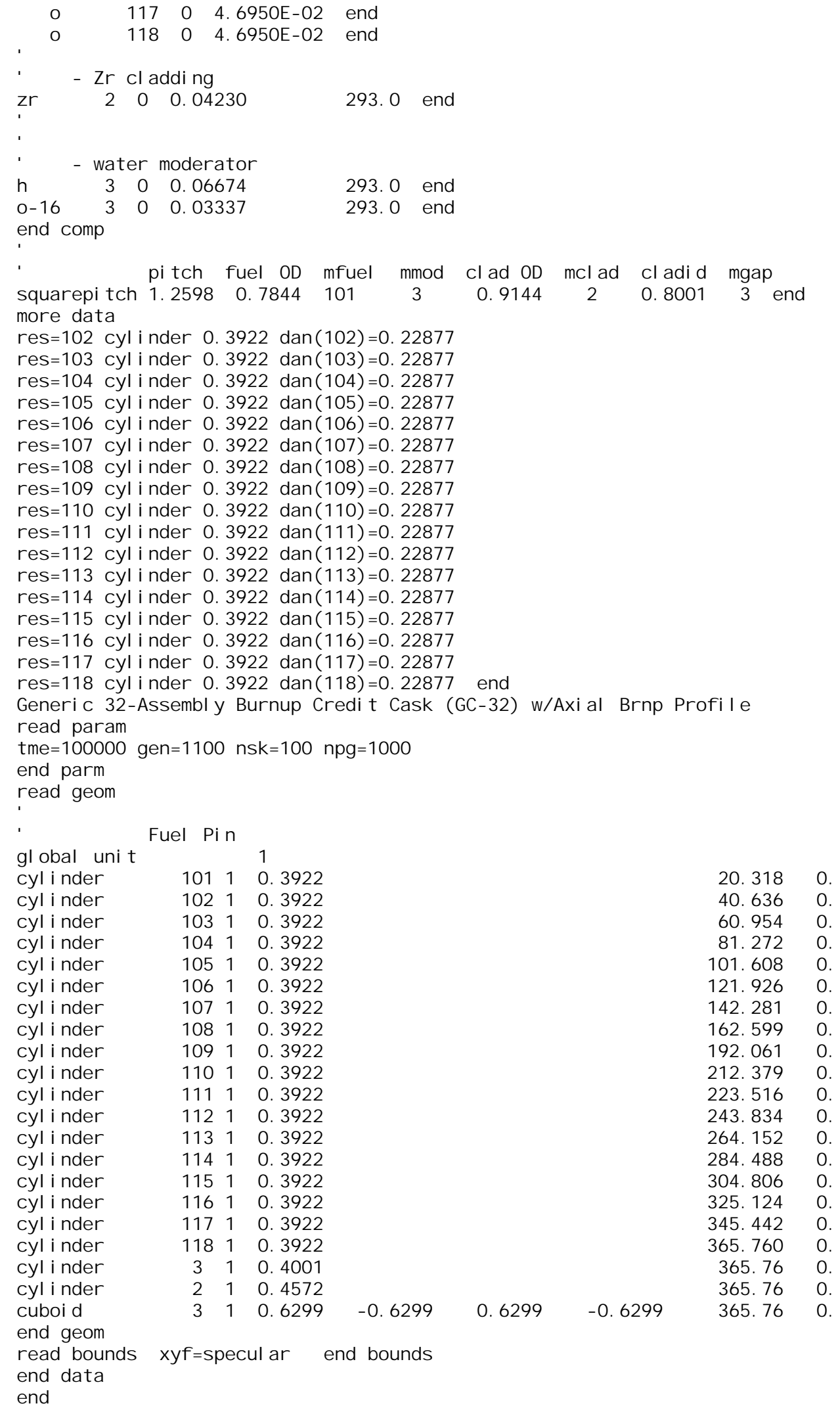


Sample 3: KRONOS XSDRN pin-cell model, actinides + fission products, $60 \mathrm{GWd} / \mathrm{MTU}$

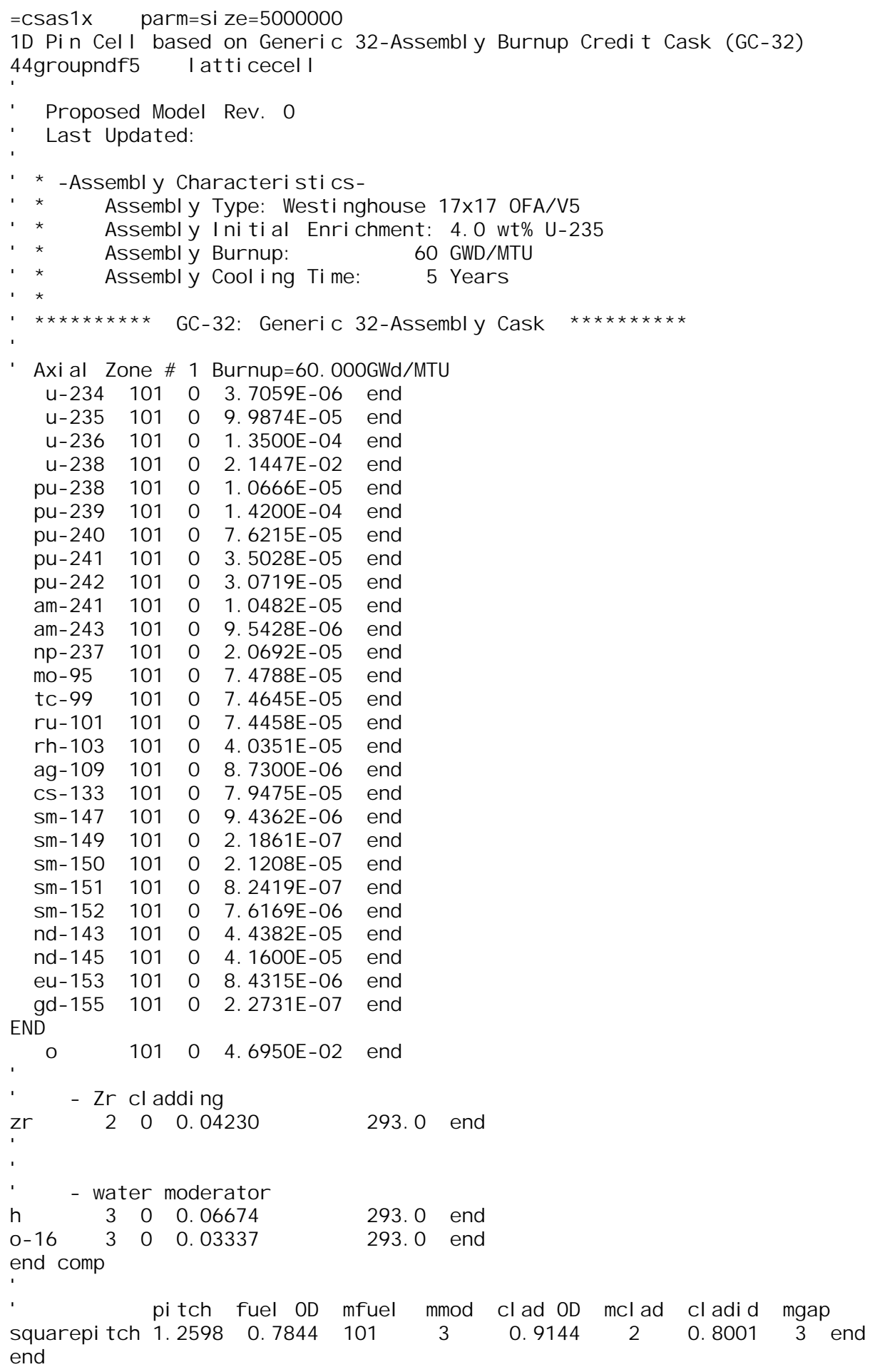




\section{ORNL/TM-2001/83}

\section{INTERNAL DISTRIBUTION}

\author{
1. C. K. Bayne, 6011, MS-6418 \\ 2. S. M. Bowman, 6011, MS-6370 \\ 3. B. L. Broadhead, 6011, MS-6370 \\ 4. W. C. Carter, 6011, MS-6370 \\ 5. M. E. Dunn, 6011, MS-6370 \\ 6. M. D. DeHart, 6011, MS-6370 \\ 7. K. R. Elam, 6011, MS-6370 \\ 8. R. J. Ellis, 6025, MS-6363 \\ 9. M. B. Emmett, 6011, MS-6370 \\ 10. I. C. Gauld, 6011, MS-6370 \\ 11. S. Goluoglu, 6011, MS-6370 \\ 12. D. F. Hollenbach, 6011, MS-6370 \\ 13. C. M. Hopper, 6011, MS-6370 \\ 14. D. T. Ingersoll, 6025, MS-6363 \\ 15. B. L. Kirk, 6025 , MS-6362 \\ 16. M. A. Kuliasha, 6025, MS-6435 \\ 17. L. C. Leal, 6011, MS-6370
}

18. C. V. Parks, 6011, MS-6370

19. L. M. Petrie, 6011, MS-6370

20. R. T. Primm, 6025, MS-6363

21. B. T. Rearden, 6011, MS-6370

22. C. E. Sanders, 6011 , MS-6370

23. J. C. Wagner, 6011, MS-6370

24. R. M. Westfall, 6011, MS-6370

25. Central Research Library 4500N, MS-6191

26. ORNL Laboratory Records - RC 4500 N- MS-6254

\section{EXTERNAL DISTRIBUTION}

27. J-H. Baik, Korea Power Engineering Company, Inc. (KOPEC), 150 Duckjin-Dong, Yusong, Taejon, South Korea 305-353

28. M. C. Brady Raap, Battelle, Pacific Northwest National Laboratory, P.O. Box 999 / MSK834, Richland, WA 99352

29. D. E. Carlson, RES/DSARE/REAHFB, U.S. Nuclear Regulatory Commission, MS T10F-13A, Washington, DC 20555-0001

30. C. W. Connell, Framatome-ANP, PO Box 10935, Lynchburg, VA 24506-0935

31. J. Conde, Consejo de Seguridad Nuclear, Justo Dorado, 11, 28040 Madrid, Spain

32. T. W. Doering, Framatome Cogema Fuels, 1261 Town Center Drive, Las Vegas, Nevada 89144

33. D. Henderson, Framatome-ANP, PO Box 10935, Lynchburg, VA 24506-0935

34. H-R. Hwang, Radiation Safety Analysis Group Manager, Korea Power Engineering Company,Inc.(KOPEC), 150 Duckjin-Dong, Yusong, Taejon, South Korea 305-353

35. R. A. Kochendarfer, Framatome-ANP, PO Box 10935, Lynchburg, VA 24506-0935

36. D. B. Lancaster, NuclearConsultants.com, 320 South Corl Street, State College, PA 16801

37. C. W. Mays, Framatome-ANP, PO Box 10935, Lynchburg, VA 24506-0935

38. J. McClure, BSC, Inc., 1261 Town Center Drive, Las Vegas, NV 89144

39. D. Mennerdahl, E. Mennerdahl Systems, Starvägen 12, S-183 57 Täby, Sweden 
40. J-C. Neuber, Framatome-ANP, Dept. NDM3, P.O. Box 101063, D-63010 Offenbach, Germany

41. R. L. Murray, North Carolina State University, P.O. Box 5596, State University Station, Raleigh, North Carolina 27650

42. P. Noel, BSC, Inc., 1261 Town Center Drive, Las Vegas, NV 89144

43. A. Nouri, OECD Nuclear Energy Agency, 12, Bd des Iles, 92130 Issy-les-Moulineaux, FRANCE

44. H. Okuno, Japan Atomic Energy Research Institute, 2-4 Shirakara-shirane, Tokai-mura, Ibaraki-ken, JAPAN 319-1195

45B46. Office of Scientific and Technical Information, U.S. Department of Energy, P.O. Box 62, Oak Ridge, TN 37831

47. J. Pegram, Framatome-ANP, PO Box 10935, Lynchburg, VA 24506-0935

48. R. E. Pevey, University of Tennessee, Nuclear Engineering Dept., 214 Pasqua Engineering Bldg., Knoxville, TN 37922

49. M. Rahimi, NMSS/DWM/HLWB, U.S. Nuclear Regulatory Commission, MS T7-F3, Washington, DC 20555-0001

50. J. Sapyta, Framatome-ANP, PO Box 10935, Lynchburg, VA 24506-0935

51. E. Sartori, OECD Nuclear Energy Agency, 12, Bd des Iles, 92130 Issy-les-Moulineaux, FRANCE

52. J. Scaglione, BSC, Inc., 1261 Town Center Drive, Las Vegas, NV 89144

53. D. A. Thomas, BSC, Inc., 1261 Town Center Drive, Las Vegas, NV 89144

54. C. J. Withee, NMSS/SFPO/TRD, U.S. Nuclear Regulatory Commission, MS O13-D13, Washington, DC 20555-0001 